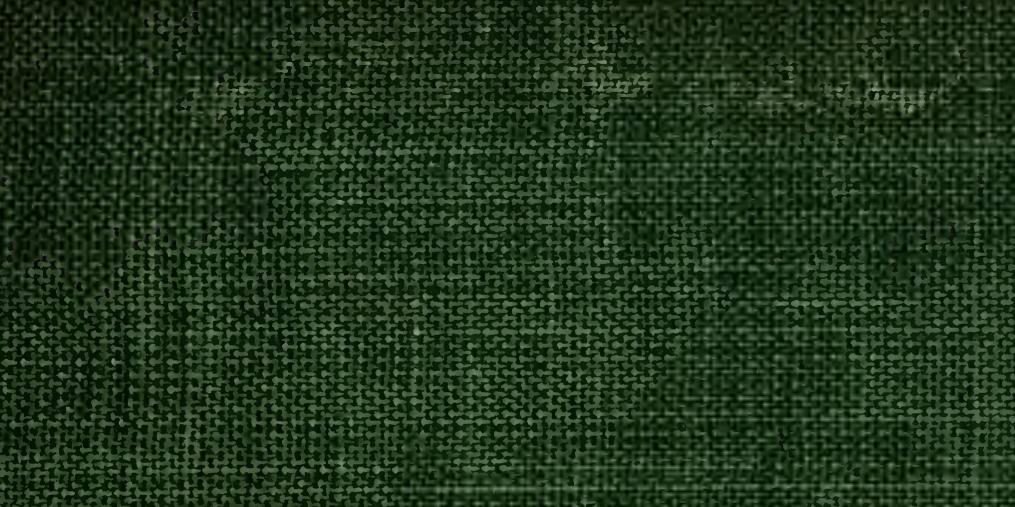
(2)

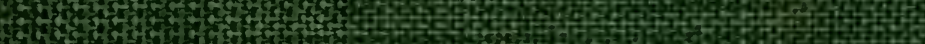

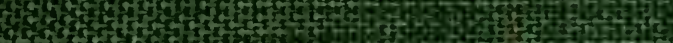

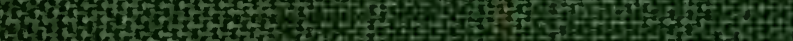

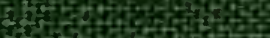

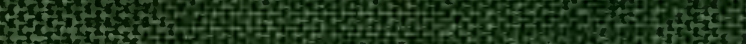
10.

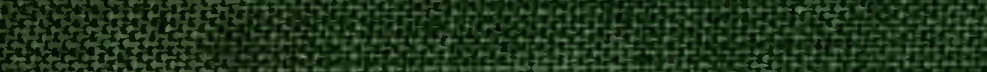

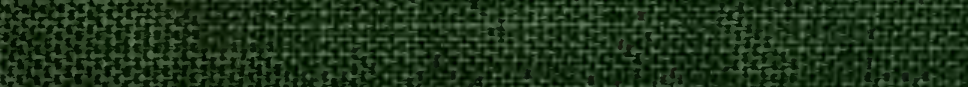

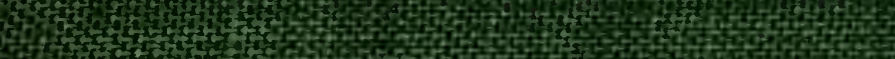
6.

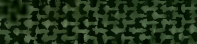

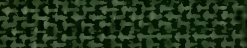
Hon

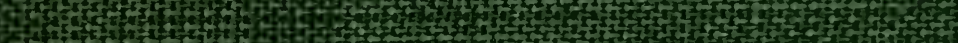

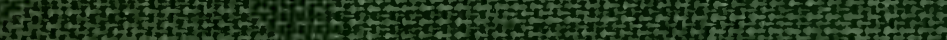

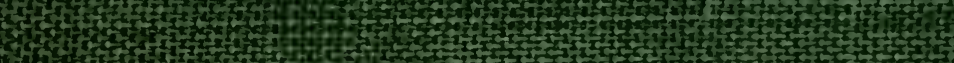

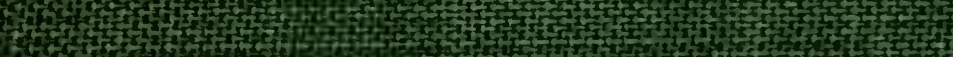

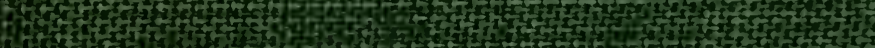

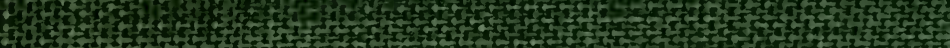

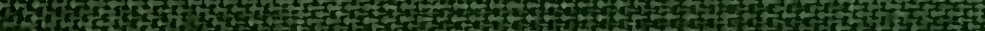

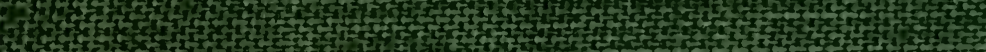
W

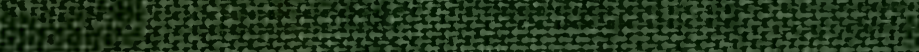
79090. A.

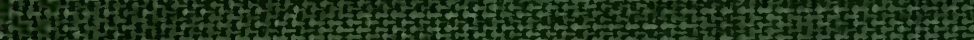
Tht 4 4.

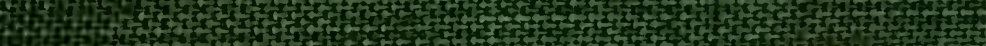

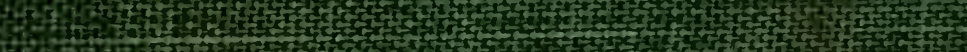

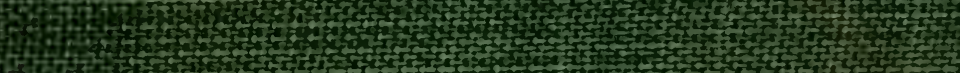

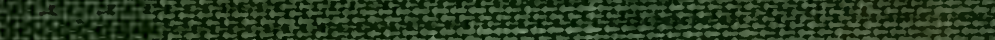

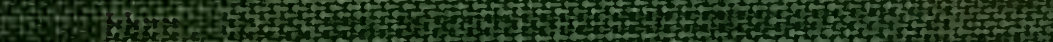


SCC

H 12.113

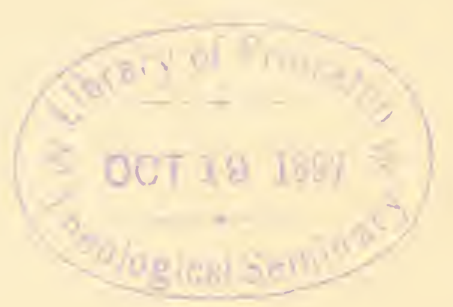

$\frac{x}{\sin =\frac{8}{8}}$

mos ...

R.L. 




\section{RELICS OF PRIMEVAL LIFE}




\section{WORKS BY SiR J. William DaWsON,}

LL.D., F.R.S., etc.

Eden Lost and Won. Studies of the Early History and Final Destiny of Man, as taught in Nature and Revelation. I2mo, cloth................... \$r.25

The work is in two parts. Part I. considers the physical and historical probabilities respecting the authorship and authority of the Mosaic books. Part II. treats of man and nature, fallen and restored.

The Historical Deluge. Its relation to Scientific Discovery and to Present Questions. I2mo, boards

......................................25

"It is a very satisfactory statement. Will be very useful." - The New York Observer.

The Meeting=Place of Geology and History.

Illustrated. Lowell Lectures, I894. I2mo, cloth I.25

"We commend these lectures heartily to all who are anxious to have a clear understanding of this important discussion."-The Living Church.

Modern Ideas of Evolution as related to Revelation and Science. Sixth Edition, Revised and Enlarged. I2mo, cloth...................... I.50

"Dr. Dawson is himself a man of eminent judicial temper, a widely read scholar, and a close, profound thinker, which makes the blow he deals the Evolution hypothesis all the heavier. We commend it to our readers as one of the most thorough and searching books on the subject yet published." - The Christian at Work.

The Chain of Life in Geological Time, A siketch of the Origin and Succession of Animals and Plants. Illustrated. Third and Revised Edition. I2mo, cloth................................... 2.00

Egypt and Syria. Their Physical Features in Relation to Bible History. Second Edition, Revised and Enlarged. With many Illustrations. "By-Paths of Bible Knowledge," Vol. VI. I2mo, cloth........ 1.20

\section{Fleming H. Revell Company}

New York: Ir2 Fifth Ave.

Chicago: $6_{3}$ Washington St.

TORONTO: $1_{40} \& I_{42}$ Yonge St. 


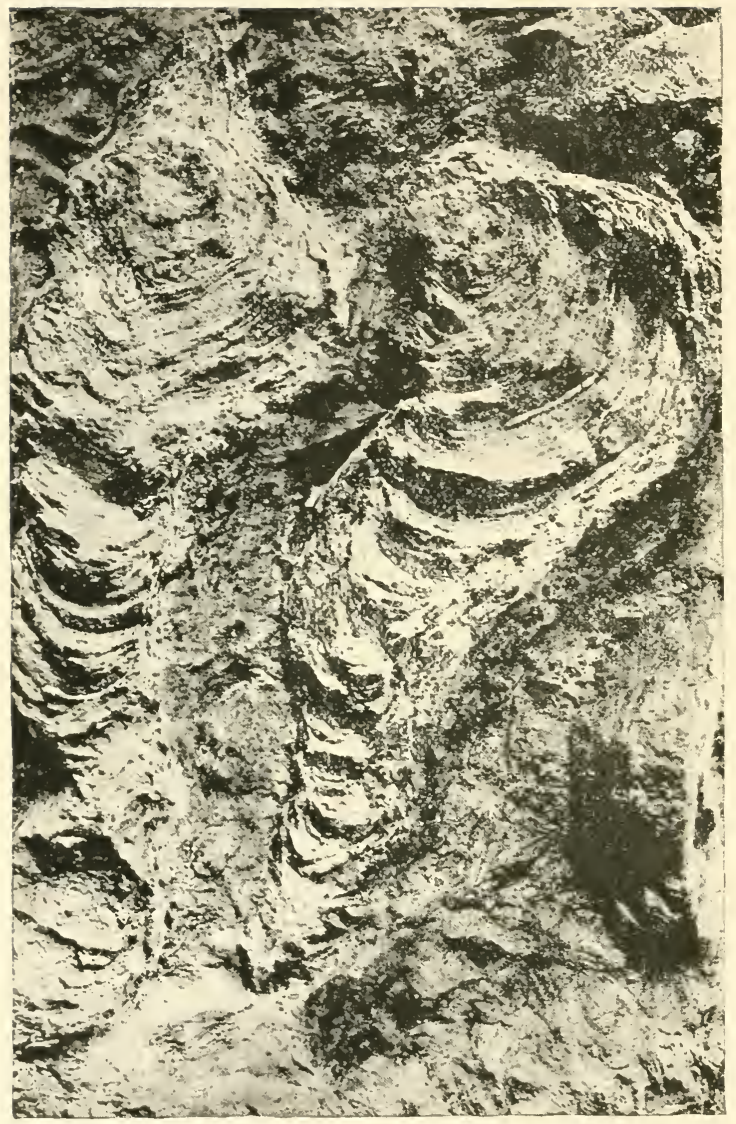

Cryptozoon Boreale, Dazuson.

lwo divisions or branches of a large specimen collected by Mr. E. T. Chambers in the Ordovician of Lake St. John. (See Appendix D.)

Frontis. 


\section{RELICS OF \\ PRIMEVAL LIFE}

BEGINNING OF LIFE IN THE

DAWN OF GEOLOGICAL TIME

BY

SIR J. WILLIAM DAWSON

LL.D., F.R.S., Етс.

WITH SIXTY-FIVE ILLUSTRATIONS

r

NEW YORK CHICAGO TORONTO

FLEMING H. REVELL COMPANY

1897 
The substance of a Course of Lectures on Pre-Cambrian Fossils, delivered in the Lowell Institute. Boston, in November, 1895 


\section{$\mathbb{T} \mathfrak{d}$}

\section{AUGUSTUS LOWELL EsQ}

Vice-President of the American Academy of Arts and Sciences Trustee of the Lowell Institute

AS THE WISE AND LIBERAL ADMINISTRATOR OF A NOBLE ENDOWMENT FOR THE ADVANCEMENT AND DIFFUSION OF KNOWLEDGE

THIS WORK IS DEDICATED WITH MUCH RESPECT AND ESTEEM BY THE AUTHOR 



\section{PREF A C E}

$\mathrm{T}^{\mathrm{T}}$ is now more than thirty-five years since the announcement was made of the discovery of remains supposed to indicate the existence of animal life in the oldest rocks known to geologists. It was hailed with enthusiasm by some as "opening a new era in geological science"; but was regarded with scepticism by others, in consequence of the condition and mineral character of the supposed fossil, and because of the great interval in time between the oldest animal remains previously known and these new claimants for recognition. Since that time, many new facts have been learned, and the question has been under almost continuous discussion and debate, with various fortunes, in different quarters. 
The author was associated with the original discovery and description of these supposed earliest traces of life; and has since, in the intervals of other work, devoted much time to further exploration and research, the results of which have been published from time to time in the form of scientific papers. $\mathrm{He}$ has also given attention to the later discoveries which have tended to fill up the gap between the Laurentian fossil and its oldest known successors.

In 1875 he endeavoured to sum up in a popular form what was then known, in a little volume named "The Dawn of Life," which has long been out of print; and in 1893 the matter was referred to in a chapter of his work "Salient Points in the Science of the Earth." In 1895 he was invited to present the subject to a large and intelligent audience in a course of lectures delivered in the Lowell Institute, Boston; and the success which attended these lectures has induced him to reproduce them in the present work, in the hope that inquiries into the Dawn of Life may prove as fascinating to general readers as to those who prosecute them as a 
matter of serious work, and that their presentation in this form may stimulate further research in a field which is destined in the coming years to add new and important domains to the knowledge of life in the early history of the earth.

Hypotheses respecting the introduction and development of life are sufficiently plentiful; but the most scientific method of dealing with such questions is that of searching carefully for the earliest remains of living beings which have been preserved to us in the rocky storehouses of the earth.

There are many earnest labourers in this difficult field, and it will be the object of the writer in the following pages to do justice to their work as far as known to him, as well as to state his own results. 



\section{O N T E N T S}

I

PAGE

The Chain of Life Traced Backivard in Geological TIME

\section{II}

Life in the Early Cambrian

III

Pre-Cambrian Life • • • • • • • 47

IV

Foundations of the Continents, and their General

Testimony AS TO LIFE. • • • • • • • 79

V

Probabilities as to Laurentian Life, and Conditions OF ITS PRESERVATION . $\cdot$.

VI

The History of a Discovery .

VII

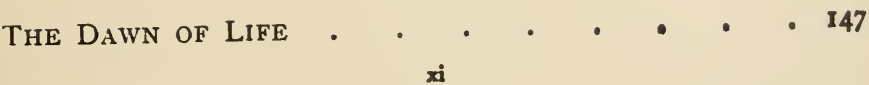




\section{VIII}

PAGE

CONTEMPORARIES OF EOZOON • • • • • • 193

IX

Difficulties and OBjections • • • • • • 22 I

$\mathrm{X}$

The ORIGIN OF LIFE .

XI

Some General Conclusions • • • : • • $28 \mathrm{I}$

\section{APPENDIX}
A. Geological Relations of Eozoon, etc. .
- 295
B. Organic Remains and Hydrous Silicates
- 298
C. Affinities of Eozoon, etc.
303
D. CRYPTOZOON
310
E. Receptaculites and Archeocyathus • • . 315
F. Pre-Geological Evolution . . • • . 320
G. Controversies respecting Eozoon . • • 324
H. Notes to Appendix, December, 1896 • • • 329 


\section{LIST OF ILLUSTRATIONS}

FIG.

PAGE

CRYptozoon Boreale . . . . Fronispiece

I. Olenellus • • • • • • • 20

2. TRIARTHRUS • • • • • • • 23

3. HYMENOCARIS • • • • • • • 27

4. CTENichnites . • • • • • • 32

5, 6. ARchжосуатнUS • • • • • • • 35

7, 8. CRYPTOZOON . • • • • • • •

9. Fossils in Lower CaMbrian BoUidder • • 41

IO. SECTION HANFORD BROOK • . • • 51

II. WORM TRACKS. • • • • • • 53

12. PRE-CAMBRIAN FOSSILS • • • • • 54

13. ARENiCOLITES AND ASPIDELla • • • 54

14. Cryptozoon • • • • • • • • 56

I5. WORM BURROWS • • • • • • . 67

16. CASTS OF FORAMINIFERA • • • • • 68

I7. TUDOR EOZOON . • • • • • . 69

I8. LAURENTIAN AMERICA • • • • • • 85

19. MaP OF GRENVille Limestones . • • . 88

19A. Attitude of Limestone, Côte St. Pierre • 9 I 20, 21. DistURBED BEDS • • • • • • . 103

22. Section of Limestone . • • • • . 112

23. Silicification OF CORAL • • • . . II 3

24. Cast of Polystomella in Glauconite • . 115 xiii 
FIG.

PAGE

24A. Crinoid and Shell in Glauconite .

- II6

25. NATURE-PRINT OF EOZOON . • • • • 121 26, 27. Eozoon from Calumet . . • . . I3O 28, 29. Canals of Eozoon . • • • • • • I33 30, 31. Canals and Tubuli . . • • • • 135

32. General form of Eozoun . • • • . I49 33, 34. EOZOON WITH FunNels. • • • • 152, 153

35. Silall Specimen and Structure • • • 155

36. Decalcified Eozoon . . . . • . 157

37. Finest Tubuli filled with Dolomite • 158

38. Arrangement of Canals . . . • . 159 39-41. Finest Tubuli . . . • . • I60-2

42. Canals after Möbius . . . . . . 163

43. Stromatocerium • • • . • • . I 172

44. Stromatopora $. \quad . \quad$. . . . 173

45. Cenostroma . . . . . . . . 174

46. Recent PRotozoa . . . . . . . 176

47. Fragmental Eozoon . . . . . . $1 \varepsilon_{3}$ 48, 49. Nummulites and Calcarina • • • . I 86 50, 51. ARCHEOSPHERINE . . . . . . 190,200

52. Acervuline EOzOON • • • • • . 205

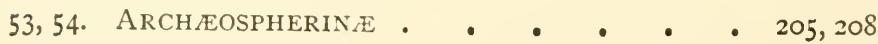

55. Ditto, Finland . • • • • • . 212

56. Eozoon Bavaricum • . . . . . 213

57. ARchÆOZOON . . . . . • • • 215

58. Restoration OF EOzOON . . . . . 230

59. Eozoon in Different States . . . . 237

60. NATURE-PRINT OF LARge SPECIMEN . To face 296 



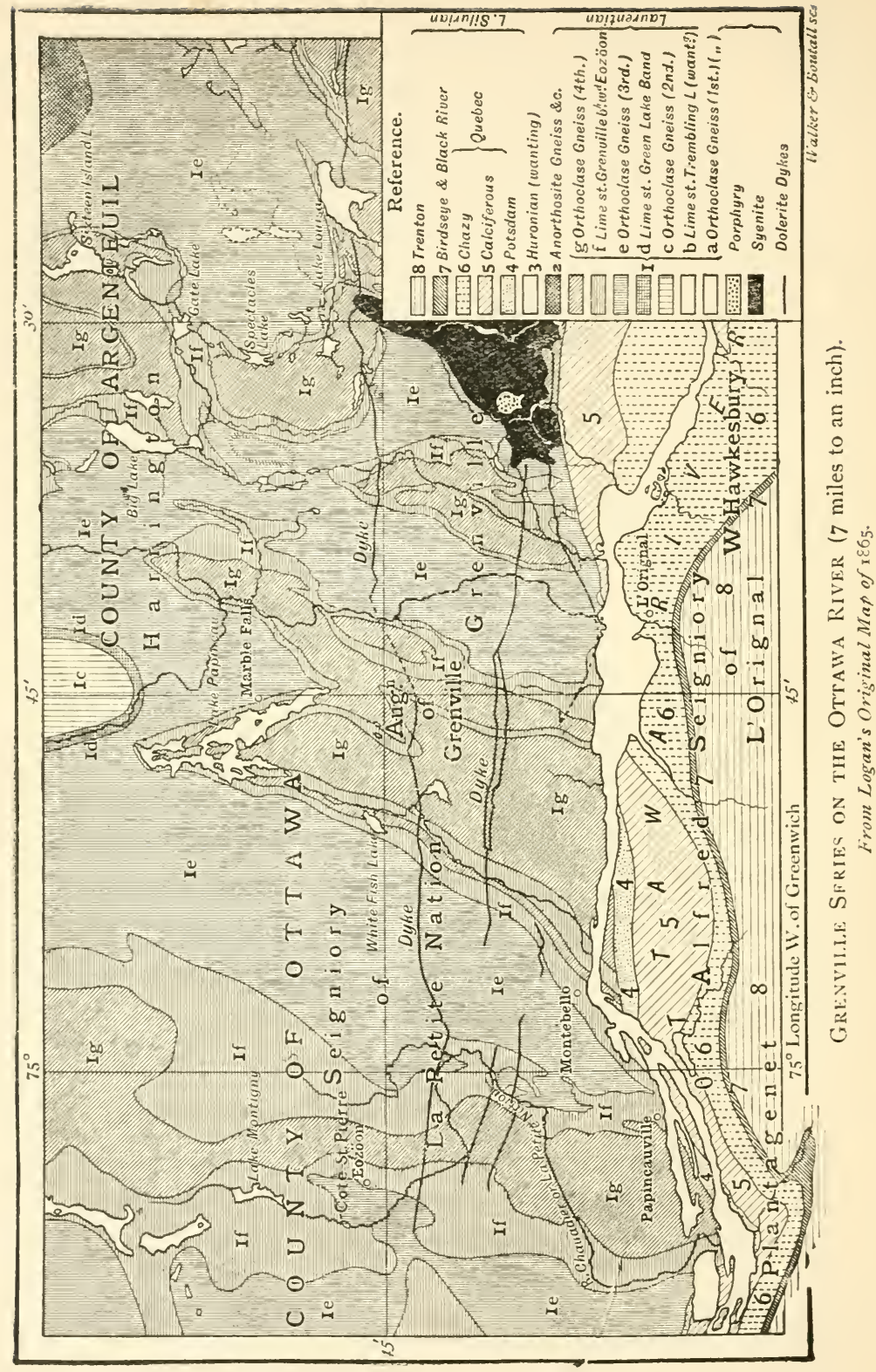


THE CHAIN OF LIFE TRACED BACKWARD IN GEOLOGICAL TIME 


\section{GEOLOGICAL CHRONOLOGY OF LIFE.}

\section{After Prof. C. A. White.}

Geological SYSTEMS OR

PERIODS.

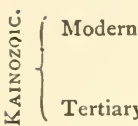

INVERTEBRATES.

VERTEBRATES.

Plants.

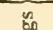

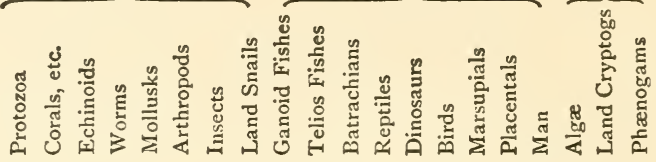

$\left\{\begin{array}{l}\text { Cretaceous .. } \\ \text { Jurassic } \\ \text { Triassic }\end{array}\right.$

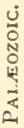

$\left(\begin{array}{ll}\text { Permian } & \ldots \\ & \\ \text { Carboniferous }\end{array}\right.$

Devonian ...

Silurian

$\frac{1}{4}$

Ordovician ...

Cambrian

Etcheminian

ن $\{$ Huronian ...
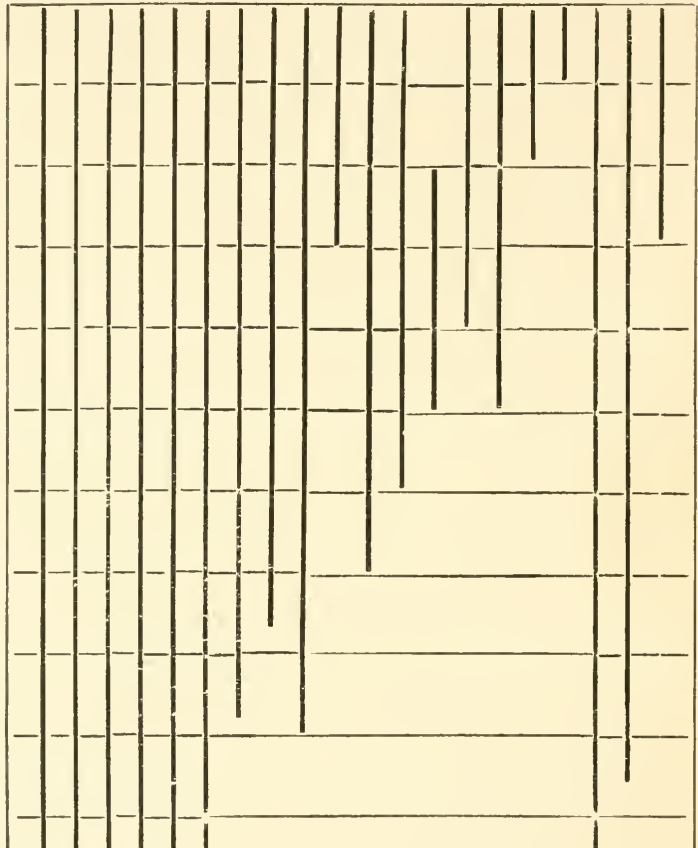
ERRATA.

Where Cryptozoon prolificum occurs in the text, read Cryptozoon proliferum. 

THE CHAIN OF LIFE TRACED BACKWARD IN GEOLOGICAL TIME

I $\mathrm{N}$ infancy we have little conception of the per1 spective of time. To us the objects around us and even our seniors in age seem to have always been, and to have had no origin or childhood. It is only as we advance in knowledge and experience that we learn to recognise distinctions of age in beings older than ourselves. In thinking of this, it seems at first sight an anomaly, or at least contrary to analogy, that the oldest literature and philosophy deal so much with doctrines as to the origins of things. In this respect primitive men do not seem to have resembled children; and the fact that our own sacred records begin with answers to such questions, and that these appear in the oldest literary remains of so many ancient nations, and even in the folk-lore of barbarous tribes, might be used as an additional argument in favour of an early Divine revelation on such subjects, as a means 
of awakening primitive men to the comprehension of their own place in the universe.

However this may be, it is certain that modern science at first took a different stand.

The constancy of the motions of the heavenly bodies, our great time-keepers, and of the changes on the earth depending upon them, and the resolution of apparent perturbations into cycles of greater or less length, impressed astronomers and physicists with the permanence of the arrangements of the heavens and their eternal circling round without any change. In like manner, on the rise of geology, the succession of changes recorded in the earth seemed interminable, and Hutton could say that in the geological chronology he could see "no vestige of a beginning, no prospect of an end."

But the progress of investigation has changed all this, and has brought physical and natural science back to a position nearer to that of the old cosmogonies. Physical astronomy has shown that the constant emission of heat and light from the sun and other stars must have had a beginning, and is hurrying on toward an end, that the earth and its satellite the moon are receding from each other, and that even the spinning of our globe on its 
axis is diminishing in rapidity. In summing up these and other changes, Lord Kelvin says: "To hold the doctrine of the eternity of the universe would be to maintain a stupendous miracle, and one contrary to the fundamental laws of matter and force."

So, on our earth itself, we can now assign to their relative ages those great mountain chains which have been emblems of eternity. We can transfer ourselves in imagination back to a time when man and his companion animals of to-day did not exist, when our continents and seas had not assumed their present forms, and even when the earth was an incandescent mass with all its volatile materials suspended in its atmosphere. It is true that in all the changes which our earth has undergone the same properties of matter and the same natural laws have prevailed; but the interactions of these properties and laws have been tending to continuous changes in definite directions, and not infrequently to accumulations of tension leading to paroxysmal vicissitudes.

If all this is true of the earth itself, it is especially applicable to its living inhabitants. Successive dynasties of animals and plants have occupied 
the earth in the course of geological time; and as we go back in the record of the rocks, first man himself and, in succession, all the higher animals disappear, until at length in the oldest fossiliferous beds only a portion of the more humble inhabitants of the sea can be found. In the time of the formation of the oldest of these rocks, or perhaps somewhat earlier, must have been the first beginning of life on our planet.

Just as we can trace every individual animal to a microscopic germ in which all its parts were potentially present, so we can trace species, genera, and larger groups of animals to their commencement at different points of the earth's history, and can endeavour to follow the lines of creation or descent back to the first beings in which vital powers manifested themselves. All such beginnings must end in mystery, for as yet we do not know how either a germ or a perfect animal could originate from inanimate matter; but we may hope at least to make some approximation to the date of the origin of life and to a knowledge of the conditions under which it began to exist, confining ourselves for the present principally to the Animal Kingdom.

As preliminary to the consideration of this subject, 
we may shortly notice the grades of animals at present existing, and then the evidence which we have of their successive appearance in different periods of geological time, in order that we may eliminate all those of more recent origin, in so far as the knowledge at present available will permit, and restrict our consideration to forms which seem to have been the earliest. In attempting this, we may use for reference the table of geological periods and animal types presented in the diagram facing this chapter, which is based on one prepared by Prof. Charles A. White, of the United States Geological Survey, with modifications to adapt it to our present purpose. In this table the leading groups of animals are represented by lines stretching downward in the geological column of formations as far as they have yet been traced. Such a table, it must be observed, is always liable to the possibility of one or more of its lines being extended farther downward by new discoveries.

The broadest general division of the Animal Kingdom is into back-boned animals (Vertebrates) and those which have no back-bone or equivalent structure (Invertebrates). ${ }^{1}$ The former includes, besides

1 The twofold primary division now sometimes used, into 
man himself, the familiar groups of Beasts, Birds, Reptiles, and Fishes. The latter consists of the great swarms of creatures included under the terms Insects, Crustaceans, Worms, Cuttle-fishes, Snails, Bivalve Mollusks, Star-fishes, Sea-urchins, Coral Animals, Sea-jellies, Sponges, and Animalcules. This mixed multitude of animals, mostly of low grade and aquatic, includes a vast variety of forms, which, though comparatively little known to ordinary observers, are vastly numerous, of great interest to naturalists, and, as we shall find, greatly older in geological date than the higher animals.

It will be seen by a glance at the diagram that the higher vertebrates are of most recent origin, man himself coming in as one of the newest of all. Only the lower reptiles or batrachians and the fishes extend very far back in geological time. None of the other vertebrate groups reach, so far as yet known, farther back than the middle of the geological scale-probably in point of time very much less than this. Those of the invertebrates that breathe air reach no farther back than the fishes, possibly not so far. On the other hand, all

Metazoa and Protozoa, seems more arbitrary and unequal, and therefore of less practical value. 
the leading groups of marine invertebrates run without interruption back to the Lower Cambrian, and some of them still farther. Thus it would appear that for long ages before the introduction of land or air-breathing animals of any kind, the sea swarmed with animal life, which was almost as varied as that which now inhabits it. The reasons of this would seem to be that the better support given by the water makes less demands upon organs for mechanical strength, that the water preserves a more uniform temperature than the air, and that arrangements for respiration in water are less elaborate than those necessary in air. Hence the conditions of life are, so to speak, easier in water than in air, more especially for creatures of simple structure and low vital energy. Besides this, the waters occupy two-thirds of the surface of the earth, and in earlier periods probably covered a still greater area.

We are now in a position to understand that the Animal Kingdom had not one but many beginnings, its leading types arriving in succession throughout geological time. Thus the special beginning of any one line of life, or those of different lines, might form special subjects of inquiry; but our present object is to inquire as to the first or earliest in- 
troduction of life in our planet, and in what form or forms it appeared. We may, therefore, neglect all the vertebrate animals and the air-breathing invertebrates, and may restrict our inquiries to marine invertebrates.

In relation to these, six of the larger divisions or provinces of the Animal Kingdom may suffice to include all the lower inhabitants of the ocean, whether now or in some of the oldest fossiliferous rocks. ${ }^{1}$

Looking more in detail at our diagram, we observe that the higher vertebrates nearest to man in structure extend back but a little way, or, with a few minor exceptions, only as far as the beginning of the Kainozoic or Tertiary Period, in the later part of which we still exist. Other air-breathing vertebrates, the birds and the true reptiles, extend considerably farther, to the beginning of the previous or Mesozoic Period. The amphibians, or frog-like

${ }^{1}$ Some modern zoologists, having perhaps, like some of the old Greeks, lost the idea of the unity of nature, or at lenst that of one presiding divinity, prefer for the larger divisions of animals the term phylum or phylon, implying merely a stock, race or kind, without reference to a definite place in an ordered kosmos. 
reptiles, reach somewhat farther, and the fishes and the air-breathing arthropods farther still. On the other hand, our six great groups of marine invertebrates run back for a vast length of time, without any companions, to the lowest Palæozoic, and this applies to their higher types, the cuttles and their allies, and the crustaceans, as well as to the lower tribes. Turning now again to our table, we find that these creatures extend in unbroken lines back to the Lower Cambrian, the oldest beds in which we find any considerable number of organic remains, and leave all the other members of the Animal Kingdom far behind.

If now we endeavour to arrange the leading groups of these persistent invertebrates under a few general names, we may use the following, beginning with those highest in rank:-

(I) Insects and Crustaceans (ARTHRopodA).

(2) Cuttles, univalve and bivalve Shell-fishes (MollusCa).

(3) Worms (ANNELIDA).

(4) Sea-urchins and Sea-stars (ECHINODERMATA).

(5) Coral Animals, Sea-anemones, and Seajellies (Cailenterata). 
(6) Sponges, Foraminifera and Animalcules of simple organization (РROTOZOA).

There are, it is true, some animals allied to the mollusks and worms, which might be entitled to form separate groups, though of minor importance The position of the sponges is doubtful, and the great mass of Protozoa may admit of subdivision; but for our present purpose these six great groups or provinces of the Animal Kingdom may be held to include all the humbler forms of aquatic life, and they keep company with each other as far as the Early Cambrian. If, in accordance with the previous statements, we choose to divide the earth's history by the development of animal life rather than by rock formations, and to regard each period as presided over by dominant animal forms, we shall thus have an age of man, an age of mammals, an age of reptiles and birds, an age of amphibians and fishes, and an age of crustaceans and mollusks.

It is only within recent years that the researches more especially of Barrande, Hicks, Lapworth, Linarrson, Brögger, and others in Europe, and of Matthew, Ford and Walcott in America, have enlarged the known animals of the Lower Cambrian to nearly 200 species, and below this we 
know as yet very little of animal life. We may therefore take the Lower Cambrian, or "Olenellus Zone" as it has been called from one of its more important crustaceans, ${ }^{1}$ as our starting-point for plunging into the depths below. In doing so, we may remark on the orderly and symmetrical nature of the chain of life, and on the strange fact that for so long ages animal life seems to have been confined to the waters, and to have undergone little development toward its higher forms. It is like a tree with a tall branchless stem bearing all its leaves and verdure at the top, or like some obscure tribe of men long living in isolation and unknown to fame, and then, under some hidden impulse or opportunity, becoming a great conquering and dominant nation. Or to compare it with higher things, it is like the Christian religion, for ages confined to a small and comparatively unimportant people, and developing slowly its faith and hopes, and then suddenly, under the personal influence of Christ and His apostles, spreading itself over the world, and in a few centuries becoming the ruling power in its greatest empire, surviving 
the fall of this and permeating all the great nations that sprang from its ruins. God's plans in nature, in history, and in grace seem to us very slow in their growth and maturity, but they are very sure. 
LIFE IN THE EARLY CAMBRIAN 

I $\mathrm{N}$ the old Chaldean fable of the descent of IshI tar into Hades, to recover her lost Tammuz, at each successive gate of the lower regions she is stripped of some of her ornaments and garments, till at length she has to appear naked and unadorned in the presence of the lord of the Nether World. So in our descent from the surface on which men live, through the successive rocky layers of the earth's crust, we leave behind, one by one, all the higher forms of life with which we are familiar; but there still remain to us our six groups of aquatic invertebrates, in the guise, it is true, of species and genera now unknown in a living state, yet well represented as far down as the lower part of the Cambrian. Let us now suppose that we take our stand on the shores of the Cambrian sea, or cast our dredge into its waters in search of 
these old animals; though we can only actually do so by painfully hammering and chiselling them out of their rocky tombs, and this often in fragments which must be put together before we can fully realize the forms and structures of the animals to which they belonged.

We may pause here, however, to remark that neither the geographical nor climatal conditions of the earth at this early time were similar to these with which we are now familiar. The marine animals of the Cambrian have left their remains in beds of sediment, which now constitute rocks forming parts of our continents remote from the sea, and much elevated above its level, showing that large areas, then under the ocean, are now dry land; while there is no good evidence that the sea and land have changed places. The facts rather indicate that the continents have extended their area at the expense of the ocean, which has, however, probably increased in depth. In evidence of these statements, I need only mention that some of the oldest rocks in the Scottish and Welsh hills, in Scandinavia, in Russia and in Bohemia, are rich in Cambrian marine fossils. In America, in like manner, such rocks are found on the flanks of the 


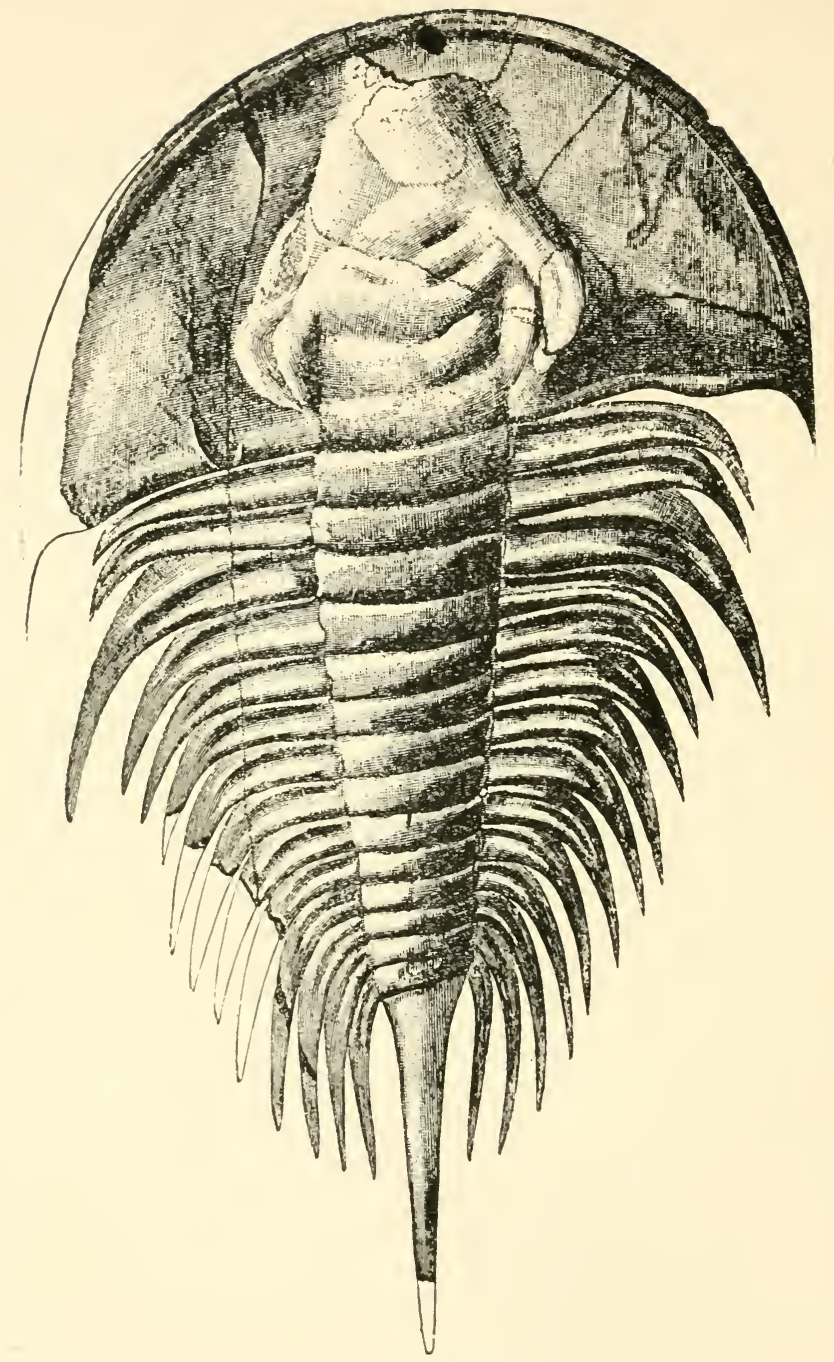

Fig. I.-Olenellus Thompsoni, Hall.

A characteristic Trilobite of the Lower Cambrian in North America. After Walcott and specimen in Peter Redpath Museum. 
Apalachians, in New Brunswick, and in Newfoundland, in the table-land of Colorado and in the Rocky Mountains. In point of fact, a map of the Northern Hemisphere at this period would show only a limited circumpolar continent with some outlying islands to the south of it, and shallows stretching across the northern part of the areas of the present Atlantic and Pacific Oceans. The great ocean, however, thus extending over most of the temperate and tropical parts of the Northern Hemisphere, was probably also more muddy and shallow than that of modern times. The surface temperature of this vast ocean was also, it is probable, more uniform than that of the modern sea, while even its profounder depths or abysses would have more earth-heat than at present. Thus we may, without hesitation, affirm that in this early age the conditions for the introduction of swarming marine life of low grade, and its extension over the whole earth, were at a maximum.

Let us inquire, then, what these old Cambrian seas actually produced, more especially in the early portions of that ancient and probably protracted time.

The most highly organized type of which we 
have any certain evidence is that of the Crustacea, the group to which our modern lobsters and crabs belong, and its most prominent representatives are the trilobites (Figs. I, 2), so called from the three lobes into which the body is divided. These creatures are indeed remarkable for the twofold property of bilateral symmetry, and fore and aft jointed structure, both based on the number three. From front to rear we have a large head, usually with well-developed eyes and oral organs, a middle or thoracic part composed of a series of movable segments, and a tail-piece sometimes small, sometimes nearly as large as the head. Transversely, the body is divided into a central and two lateral lobes, which can be seen in the head, the thorax, and usually in the tail as well. The organization of these animals must have been as complex as that of most existing Crustaceans. Their nerve system must have been well developed; a vast number of muscles were required to move the different parts of the trunk, and the numerous and complex limbs which have been observed in some of the species, and no doubt were possessed by all. Their digestive and circulatory organs must have been in proportion to the complexity of their locomotive organs. Figure 2, 


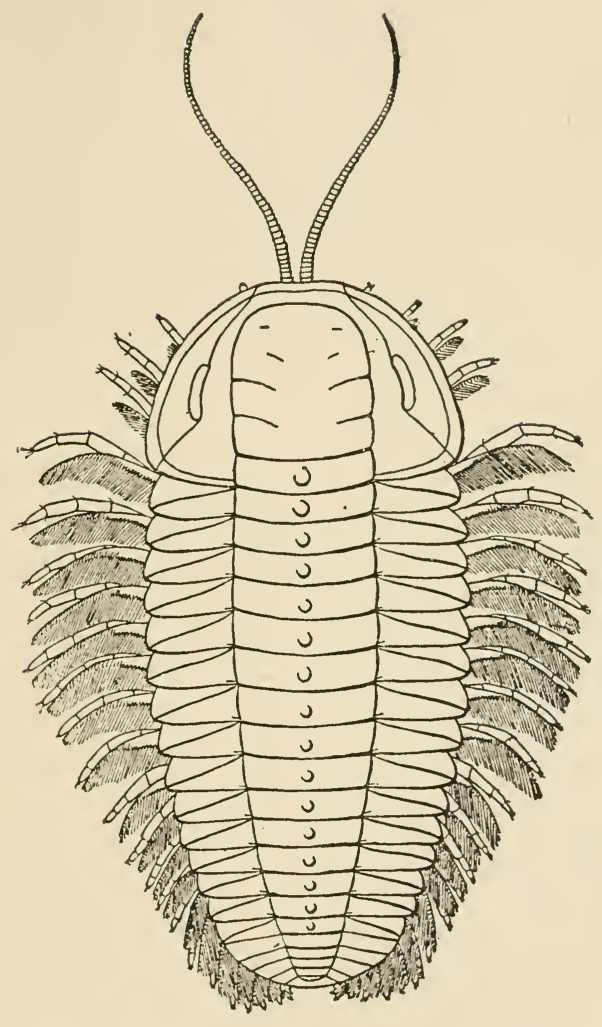

FIG. 2.-Triarthrus Becki, Green.

A Trilobite of primitive type, showing its limbs and antennæ. (After Beecher.) 

borrowed from Beecher, ${ }^{1}$ shows the limbs of a species, not of the Lower Cambrian, but of a somewhat later formation. There can be no doubt, however, that those of earlier species were equally perfect, more especially as Triarthrus is an animal of an old type approaching to extinction in the age succeeding the Cambrian, and its representatives in the earlier and palmy days of the family could not have been inferior in organization. These creatures swarmed in every sea in the Cambrian period, and were represented by a great number of species, some of them of large size, others very small; some many-jointed, others few - jointed, and with a great variety of tubercles, spines, and other ornamental and protective parts. If we ask for their affinities and place in the great group of Crustacea, the answer must be that, while in some points allied to the higher forms, they approach most nearly to those which occupy a medium position in the class, and are, in fact, a composite type, presenting points of structure now distributed among different groups. If we ask for affinities with lower groups, we have to reply that their nearest allies in this direction are

1 American Journal of Science, 1896. 
the bristle-footed marine worms; but there is a vast gap, both in the Cambrian and Modern seas, between any of these worms and the Crustacea, which, either as embryos or as adults, have any resemblance to them.

The Trilobites, after appearing in a great variety of generic and specific forms, and playing a most important part in their time, were not destined to continue beyond the Carboniferous period, and before that time they were beginning to give place to the Limuli, King-crabs, or Horseshoe-crabs, a few species of which continue on our coasts until the present time. In this limited duration the Trilobites present a strange contrast to certain shrimp-like Crustaceans, their contemporaries (the Phyllopods), which very closely resemble some still extant, and the same remark applies to swarms of little bivalve Crustaceans (Ostracods), which are still represented by hosts of modern species both in the sea and in the fresh waters. There is, however, a remarkable group of shrimp-like Crustaceans, represented in the modern world by only a few small species, which in the Cambrian age attained greater size, and constitute a very generalized type combining characters now found in lower and higher groups of Crustacea. 
Hymenocaris vermicauda of Salter (Fig. 3) may serve to illustrate one of these primitive forms.

In point of fact, as Dr. Henry Woodward has shown in an able presidential address delivered to the Geological Society in I895, at the base of the Lower Cambrian we still have several distinct groups of Crustacea; and if with some we were to hold them

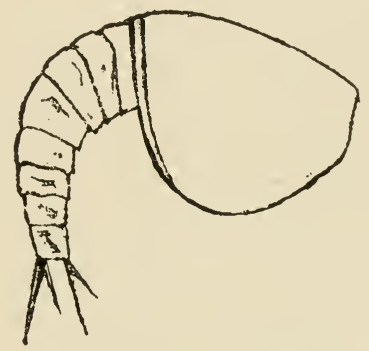

FIG. 3.-Hymenocaris vermicauda, Salter.

A Lower Cambrian Shrimp of generalized type. (After Salter.)

as traceable to one original form or to a worm-like ancestor, we must seek for this far back in those pre-Cambrian rocks in which we find no Crustaceans whatever. There is, it is true, no good reason to demand this; for whatever the cause, secondary or final, which produced any form of Crustacean in the Lower Cambrian, it might just as well have produced several distinct forms. Evolutionists seem 
to be somewhat unreasonable in demands of this kind, for any cause capable of originating a new form of living being, might have been operative at the same time in different localities and under somewhat diverse conditions, and may also have acted at different times. All imaginary lines of descent of animals are more or less subject to this contingency; and this may partly account for the great diversity in the lines of affiliation presented to us by evolutionists, which may in part have a basis in fact in so far as distinct varietal and racial forms are concerned, but may just as likely be entirely fallacious in the case of true species. In any case, in the lowest rocks into which we can trace Crustacea, we have already probably five of the orders into which their successors in the modern seas are divided by zoologists; and this is certainly a singular and suggestive fact, the significance of which we shall be better prepared to understand at a later stage of our investigation.

Allied in some respects to the Crustacea, though much lower in grade, are the marine Worms-a great and varied host-usually inhabiting the shallower parts of the ocean; though the 330 species collected by the Challenger expedition show that 
they also abound in those greater depths to which voyagers have only recently had access. Sea-worms seem thus to be able to live in all depths, as well as in all climates; and in accordance with this they abound in the oldest rocks, which are often riddled with the holes caused by their burrowing, or abundantly marked on the surfaces of the beds with their trails.

The great province of the Mollusca, in which, for our present purpose, we may include some aberrant and rudimentary Molluscoids, is now best known to us by its medium types, the univalve and bivalve Shell-fishes; the higher group of the Cuttlefishes and Nautili, though not uncommon, being much less numerous, and one at least of the lower groups, the Lamp-shells or Brachiopods, being represented in the modern world by but few forms. The extension of the Mollusks backwards into the Cambrian is remarkable as being on the whole meagre in comparison with that of the Crustaceans, and as presenting only in small numbers the types most common in later times. One or two shells, and perhaps some tracks, represent the highest group: some forms resembling the floating species of Seasnails, and a very few ordinary bivalves represent 
the types best known in the modern seas; while the Brachiopods, and probably some still simpler forms, are in great comparative excess. The individual specimens are also of small size, as if these creatures were but insinuating themselves on the arena of life in insignificant and humble forms. So far as yet known, the lowest groups supposed to be allied to the Mollusks, the Ascidians or Seasquirts, and the Sea-mosses (Polyzoa), do not appear; but they may have been represented by species which possessed no hard parts capable of preservation.

This leads us to the consideration that while all the Crustacea necessarily possess some kind of crust or external skeleton, the Mollusks are very different in this respect. While some of them have ponderous shells, others even of the highest forms are quite destitute of such protective parts. This again leads to a curious question respecting the armature of the Trilobites. Some of these, even of the larger species, have strong and formidable spines, like those of the King-crabs and other modern Crustaceans. Now in the modern species we know these organs to be intended to defend their possessors against the attacks of fishes 


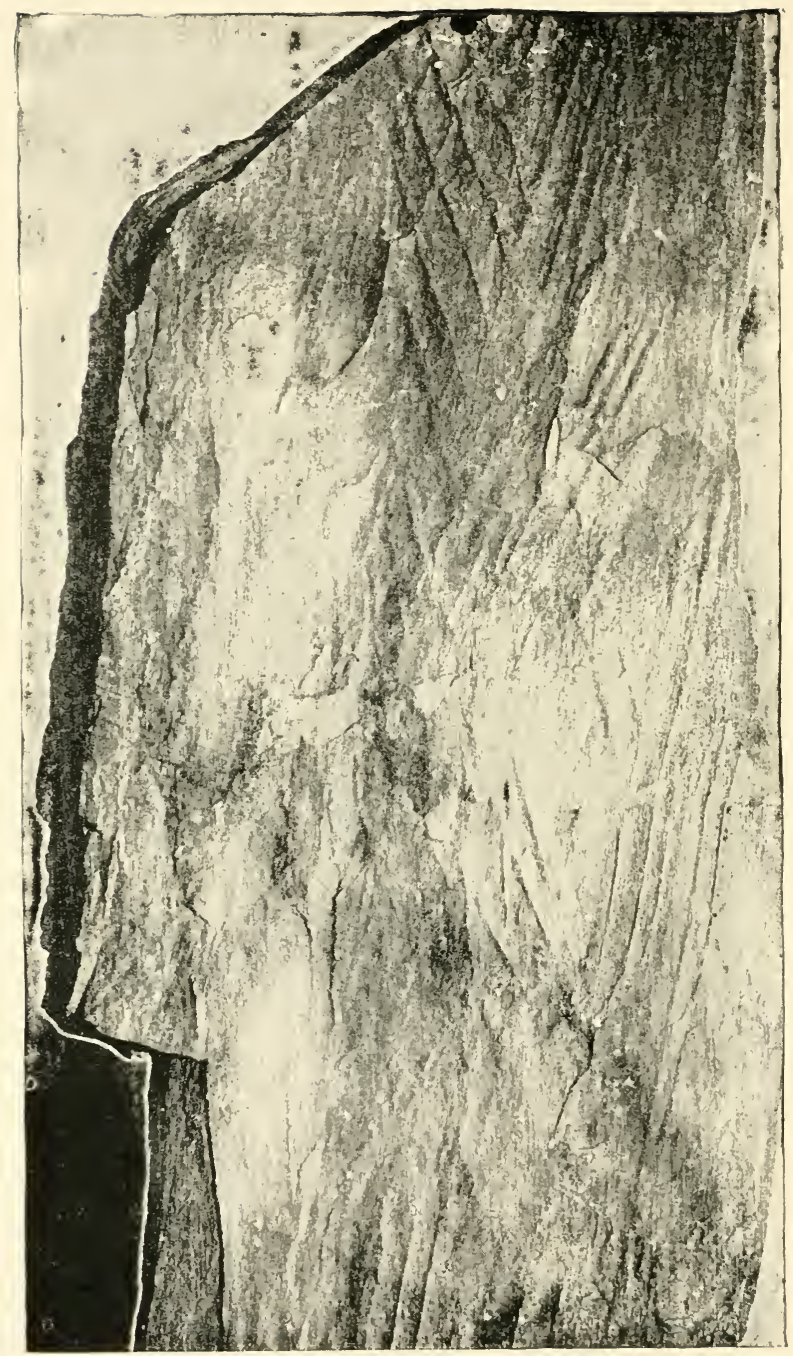

FIG. 4.-Ctenichnites ingens, Matthew.

A slab with markings of aquatic animals. From specimen in Peter Redpath Museum. 
more swift and powerful than themselves. But what enemies of this kind had the Trilobites to dread? Yet species a foot or more in length presented great bayonet-like spines. All that we know on this subject is that on the surfaces of the Lower Cambrian rocks there are in some places complicated and mysterious tracks or scratches, which seem to have been produced when the rock was in the state of soft mud, by large and swiftly swimming animals possessing some sort of arms or similar appendages (Fig. 4). Matthew has ingeniously suggested that they may have been large Mollusks allied to the modern gigantic Squids which still abound in the ocean, that they may have been sufficiently powerful to prey on the Trilobites, and, being swift swimmers, would have found them a helpless prey but for their defensive spines. Yet such large Mollusks might have perished without leaving any remains recognisable in the rocks, except what may be termed their handwriting on clay. A few small examples of the shellbearing species of these highest Mollusks, however, appear in the Cambrian, and in the succeeding ages they become very abundant and attain to large dimensions, again dwindling toward modern times. 
It would thus seem that for some unknown reason the highest and lowest Mollusks may have been locally plentiful, but the intermediate types were rare.

The much lower group of Echinoderms, or Seaurchins and Sea-stars, curiously enough puts in but a small appearance in the Early Cambrian, being represented, as far as yet known, by only one embryonic group, the Cystideans. A little later, however, Feather-stars became greatly abundant, and a little later still the true Star-fishes and Urchins. The aberrant group of the Sea-slugs seems, so far as known, to be of more modern origin; but most of these animals are soft-bodied, and little likely to have been preserved.

The great group of the coral animals, so marked a feature of later ages, is scarcely known in the oldest Cambrian, except by some highly generalized forms ${ }^{1}$ (Fig. 5). There are, however, small Zoophytes referable to the lower type of Hydroids, and markings which are supposed to be casts of stranded

${ }_{1}$ Dr. G. J. Hinde has carefully studied these forms, and also similar species occurring in Lower Cambrian beds in different parts of North America, Spain, Sardinia, and elsewhere. See note in the Appendix, and Journal Geol. Society of London, vol. xlv. p. 125 . 


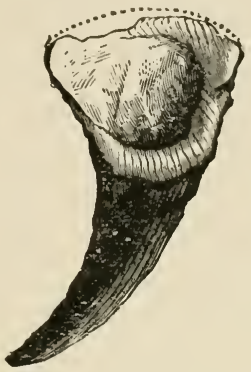

FIG. 5.-Archiocyathus profundus, Billings.

Possibly a Coral of generalized type from the Lower Cambrian of L'Anse à Loup, Labrador. A small specimen.

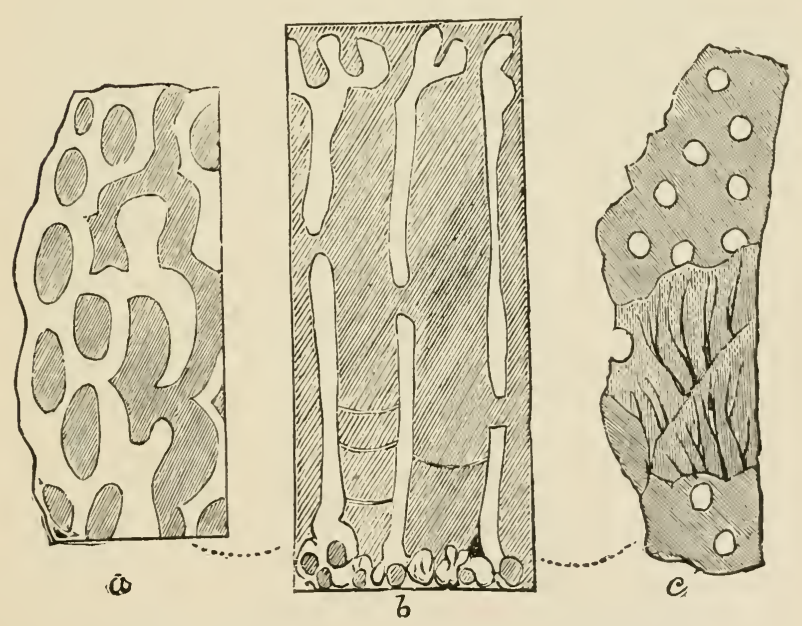

FIG. 6.-Structures of $A$. profundus (magnified).

From specimens in Peter Redpath Museum.

(a) Lower acervuline portion. (b) Upper part, with three of the radiating lamina and section of pores. (c) Portion of lamina, with pores, the calcareous skeleton unshaded. 
Jelly-fishes. If, with some naturalists, we regard the Sponges as very humble members of the coral group (Cœlenterata), then we have a right to add them to its representatives in the lowest Cambrian; but perhaps they had better be ranked with the next and lowest group of all-the Protozoa.

These are the humblest of all the inhabitants of the sea, presenting very simple, jelly-like bodies with few organs, but sometimes producing complex and beautiful calcareous and siliceous coverings or tests. Animals of this type have been found in the Lower Cambrian, though not in such vast multitudes as in some later formations. There are also in the Cambrian some large, laminated, calcareous bodies (Cryptozoon of Hall), to be noticed more fully below, and which have recently been traced in still lower deposits even below the lowest Cambrian (Figs. 7, 8). These have some resemblance to the layer-corals or stromatoporæ of the Silurian and Ordovician, which are by many regarded as the skeletons of coral animals of a low type; but the microscopic structure of Cryptozoon rather allies it with some of the larger forms of Protozoa found higher up in the series of formations. We shall have to discuss this later in connection with still older fossils. 


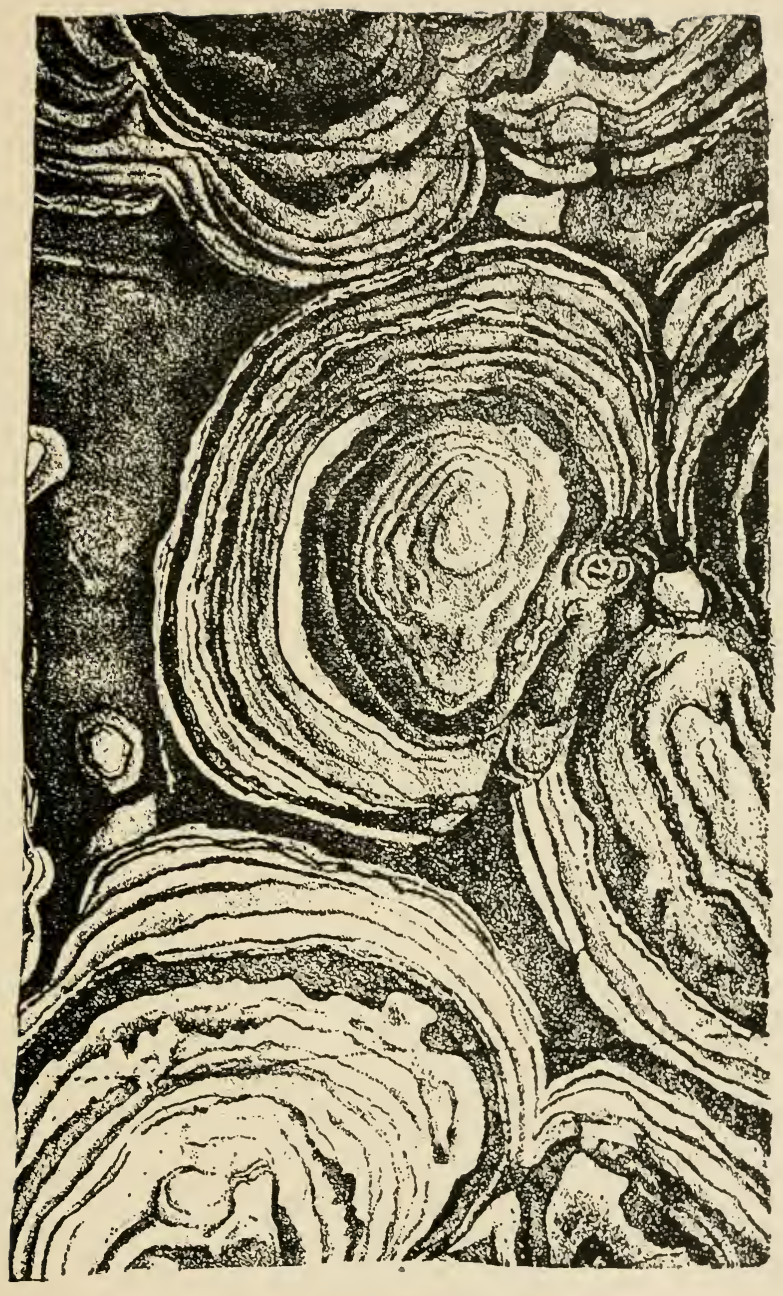

Fig. 7.-Cryptozoon frolificum, Hall.

Portion of slab reduced in size. (After Hall.) See also Fig. 6r, p. 3 to. 



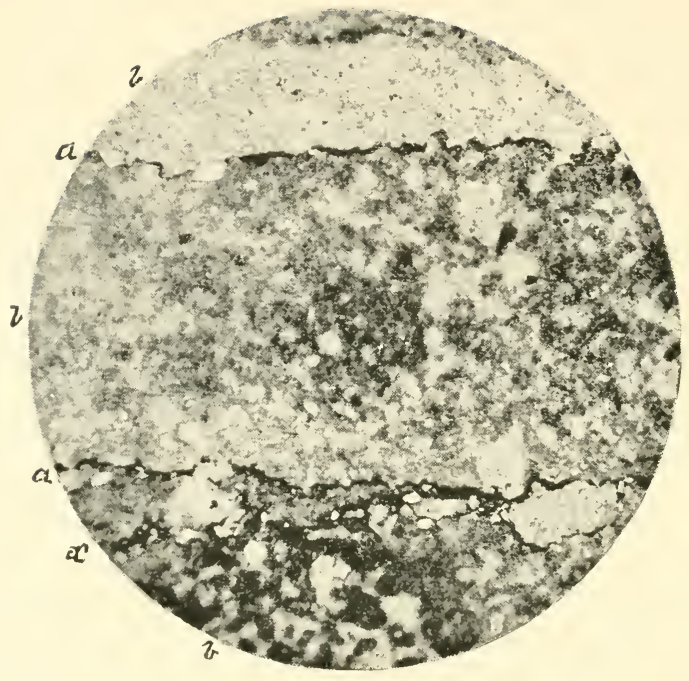

FIG. 7a.-Portion of thin section of Cryptozoon proliferum (magnified $\times 50$ ).

(a) Corneous layers. ( $\left.a^{1}\right)$ One of these dividing. (b) Intermediate stroma with granules of calcite, dolomite and quartz, traversed by canals.

From a Micro-photograph by PROF. PENHALLOW. 
If now in imagination we cast our tow-net or dredge into the sea of the Lower Cambrian, we may hope to take specimens illustrative of all our six groups of invertebrate animals, and under several of them examples of more than one subordinate group. Of the Crustaceans we might have representatives of four or five ordinal groups, and

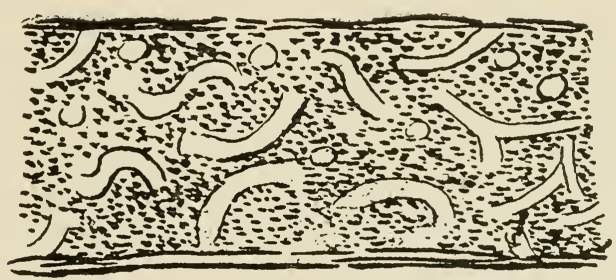

FIG. 8.-Diagrammatic section of two Lamina of Cryptozoon, showing the Canals of the intermediate space, or Stroma (magnified).

Specimen in Peter Redpath Museum.

of the Mollusca as many. These are the two highest and most complicated. In the four lower groups we would naturally have less variety, though it would seem strange, were it not for so many examples in later periods, that the dominant and highest groups should be most developed in regard to the number of their modifications.

Of the whole we might perhaps have been able to secure at least 200 species even in one locality. 
The likelihood is that if there had been a collecting expedition like that of the Challenger in Early Cambrian times, it could have secured thousands of specific forms representing all the above types, more especially as we probably know very little of the softer and shell-less animals of these old seas, and there is some reason to believe that these may have been in greater proportion than in the present ocean.

In illustration of the richness of some parts of the lowest Cambrian sea, I may refer here to the large and beautifully illustrated Memoir of Walcott on the Lower Cambrian, containing fifty folio plates of species collected in a few districts of North America; and, as a minor example, to the contents of a loose boulder of limestone of that age, found at Little Metis on the Lower St. Lawrence, under the following circumstances (Fig. 9):-

Along what is now the valley of the Lower St. Lawrence and the gulf of the same name, there seem to have been deposited in the oldest Cambrian or Olenellus period beds of limestone rich in shells of marine animals and fragments of these. These can be seen in place in some parts of Newfoundland, and here and there on the 


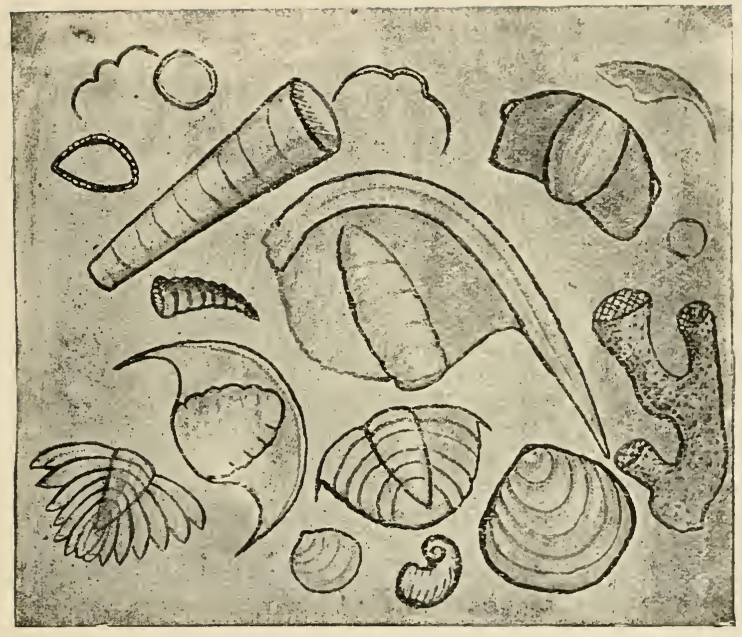

Fig. 9.-Lower Cambrian Fossils found in a fiw cubic inches of limestone in a conglomerate at Little Metis; viz., Trilobites of genera Olenellus, Ptychoparia, Solenopleura, Protypus; Brachiopod of genus Iphidea; Pteropod of genus Hyolithes; Gastropod, genus Stenotheca; Sponge, undetermined. 

hills bounding the St. Lawrence River; but for the most part they have been swept away by the sea when these districts were being elevated to form parts of the American land. Their ruins appear as boulders and pebbles in thick beds of conglomerate or pudding-stone, constituting portions of the Upper Cambrian and Lower Ordovician series, which now occupy the south coast of the Lower St. Lawrence. In one of these boulders, less than a foot in diameter, removed from its hard matrix and carefully broken up, I found fragments representing eleven different species, of which no less than eight were trilobites, one a gastropod, one a brachiopod, and one probably a sponge-and this forms an interesting illustration of the number of species sometimes to be found in a limited space, and also of the great prevalence of the Trilobites in these beds. The statistics of these groups for North America, as given by Walcott, show 165 species belonging to all the groups enumerated above, and of these the Trilobita constitute one-third of the whole; so that the Olenellus Zone, as it has been called from one genus of these Crustaceans, might well be named the reign of Trilobites, unless, indeed, as the indications already referred to seem to 
show, giant cuttle-fishes, destitute of shells, were then the tyrants of the sea, but are represented only by the markings of their long and muscular arms on the soft sea mud while dashing after their Crustacean prey. What I desire, however, chiefly to emphasize is, that in the lowest beds of the Cambrian we have evidence of sea-bottoms swarming with representatives of all the leading types of marine invertebrate life, and therefore seem to be still far from the beginning of living things, if that was a slow and gradual process, rather than a sudden or rapid series of events. 


\section{PRE-CAMBRIAN LIFE}





\section{III}

\section{PRE-CAMBRIAN LIFE}

U AVING traced the chain of life through the long geological ages, from the present day back to the Cambrian Period, we may now take our stand on the fauna of the lowest Cambrian or Olenellus Zone, as a platform whence we may dive into still deeper abysses of past time. Here, however, we seem to have arrived at a limit beyond which few remains of living things have yet been discovered, though there still remain pre-Cambrian deposits of vast thickness and occupying large areas of our continents. These pre-Cambrian formations are as yet among those least known to geologists. The absence of fossils, the disturbances and alterations which the rocks themselves have undergone, and which make their relative ages and arrangement difficult to unravel, have acted as deterrents to amateur geologists, and have to some extent baffled the efforts of official explorers. In addition to this, workers in different regions have adopted different 
methods of arrangement and nomenclature; and in a very recent address, the Director-General of the Geological Survey of Great Britain expresses his inability to satisfy himself of the equivalency of the different pre-Cambrian groups on the opposite sides of the Atlantic, and in consequence prefers to retain for those of Britain merely local names.

On the other hand, those who hold the modern theories of gradual evolution repudiate the idea that the Lower Cambrian fauna can be primitive, and demand a vast series of changes in previous time to prepare the way for it. In any case this comparatively unexplored portion of geological time holds out the inducement of mystery and the possibility of great discoveries to the hardy adventurers who may enter into it. It must now be our effort to explore this $\operatorname{dim}$ and mysterious dawn of life, and to ascertain what forms, if any, are visible amid its fogs and mists.

The Kewenian or Etcheminian.

In certain basal Cambrian or infra-Cambrian beds, found by Matthew in Southern New Brunswick, by Walcott in Colorado, and by Scandinavian and English geologists in their respective countries, 
we find a few remains referred to Algæ, or seaweeds; small tests or shells of Protozoa; burrows and trails similar to those of modern sea-worms; a few bivalve shells allied to modern Lingulæ, but presenting some remarkable generalized characters; some bivalve and shrimp-like Crustaceans, spicules of sponges, and large laminated forms (Cryptozoon) similar to those already referred to as occurring in the Upper Cambrian; also certain mysterious markings that are supposed to have been produced by the arms or tentacles of free-swimming animals of various kinds. In these lower beds the Trilobites have nearly or quite disappeared, being represented only by doubtful fragments. The beds of rock, originally sandy or muddy sediments, contain fossils very sparingly, and only in certain layers separated by great thicknesses of barren material, as if earthy matters were being deposited very rapidly, or as if animal life was rare on the sea-bottom except at intervals. It has, however, been suggested as possible $^{1}$ that much of the marine population in thuse early times consisted of pelagic or swimming animals destitute of any hard parts that could be

1 By Prof. Brookes, of Johns Hopkins University. 
preserved. In addition to biological arguments in favour of this view, there is the fact that some of the beds are stained with carbonaceous or coaly matter, as if the sediment had been mixed with decomposed remains of plants or animals retaining no determinate forms. Future discoveries may increase our knowledge of the life of this period preceding the Cambrian, but it is evident that so far as these rocks have been examined, they indicate a great step downward in regard to the variety and complexity of marine life.

Still we must bear in mind that in later periods there have been times of rapid deposition, in which, in certain localities at least, great thicknesses of rock with few organic remains were formed. We have instances of this in the later Cambrian, in the Ordovician, and still later in the Permian and Trias. Thus in the beds immediately underlying the lowest Cambrian we may be passing through a tract of comparative barrenness to find more fertile ground below.

It is also to be observed that there is evidence of disturbance occurring in the interval between the lowest Cambrian and the highest pre-Cambrian, which may involve the lapse of much time not 
recorded in the localities hitherto explored, but of which monuments may be found elsewhere.

We may now, taking some North American localities as our best available guides, inquire as to the nature and contents of the beds next below the Lower Cambrian.

In Southern New Brunswick, Matthew indicated, several years ago, the occurrence of certain conglomerates and sandy and slaty beds over the rocks, mostly of igneous origin, constituting a great thickness of beds under the Cambrian, and known locally as the "Coldbrook" series, which is probably equivalent to the Huronian of Northern and Western Canada, to be noticed later. These beds were at first regarded as an upper member of the Huronian, but subsequently it was thought better to unite them with the overlying Cambrian as basal Cambrian.

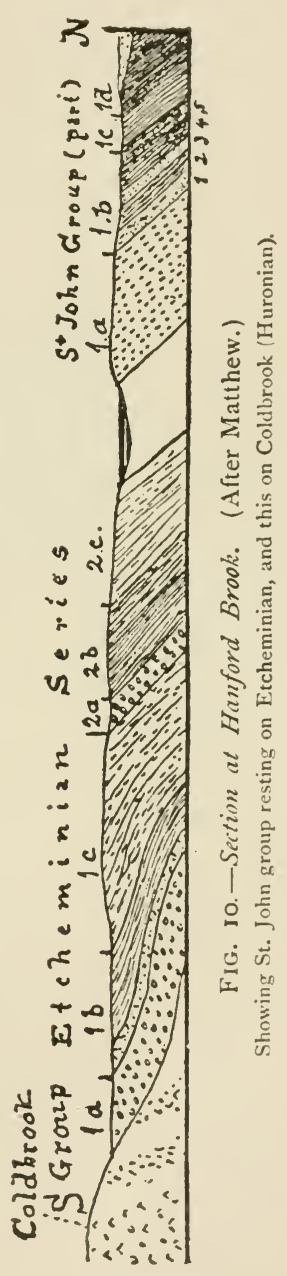


The fact that these problematical beds were ascertained to be unconformable to the Cambrian, and the peculiarity of their fossils, led to their being constituted a separate group under the name Etcheminian, which seems to represent a time and conditions introductory to the Cambrian (Fig. IO). The fossils in these beds are few and hard to find. Matthew has kindly furnished me with the following list. ${ }^{1}$ The Trilobites are conspicuous by their absence. Seaworms have left burrows, trails, and casts, which probably represent several species (Fig. I I). A single little shell (Volborthella) is supposed to be a precursor of the straight chambered shells allied to the modern nautilus, which become so large and numerous in succeeding periods. There are a few univalve shell-fishes allied to modern sea-snails, a brachiopod of the antique genus Obolus, some fragmeats supposed to represent Cystideans, a rudimentary type of the stalked sea-stars so abundant later, spicules of sponges and minute Protozoa, with shells not unlike those of their modern successors. This meagre list sums up the forms of life known in the Etcheminian of this district, one in which the Cambrian beds

1 "Transactions Royal Society of Canada," vol. vii. 

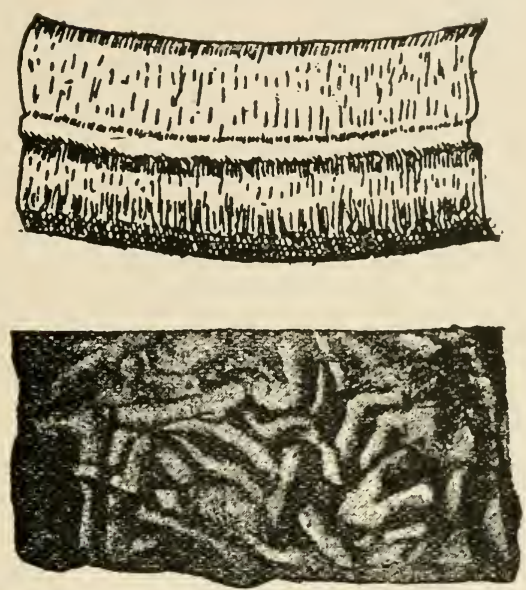

FIG. 11.-Trails of Worms of two types (Psammchnites and Planilites).

exhibit the rich and varied fauna of Trilobites and other animals described and figured by Matthew in several successive volumes of the "Transactions of the Royal Society of Canada” (Fig. I2).

Beds in Newfoundland (the Signal Hill and Random Sound series), underlying the Lower Cambrian, have afforded to Murray and Billings some well-characterized worm-castings of spiral form, and a few problematical forms known as Aspidella, which may be Crustaceans or Mollusks allied to the limpets (Fig. I3).

In a thick series of pre-Cambrian beds in the 


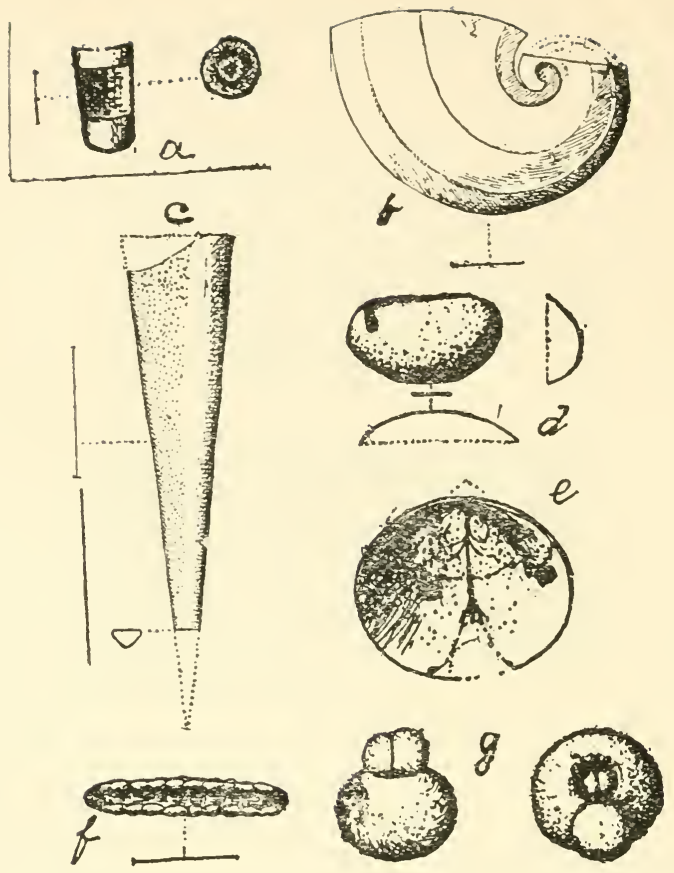

FIG. I2.-Grous of pre-Cambrian (Etcheminian) Animals from the Etcheminian. (After Matthew.)

The name "Etcheminian" is derived from that of an ancient Indian tribe of New Brunswick.

(a) Volborthella, supposed to be a Cephalopod shell. (b) Pelagiella. (c) Orthotheca, supposed to be Pteropods. ( $d$ Primitia, an Ostracod Crustacean. (e) Obolus, a Brachiopod shell. (f) Platysolenites, probably fragment of a Cysticiean. (g) Globigerinæ, casts of Foraminiferal shells, Etcheminian, New Brunswick.
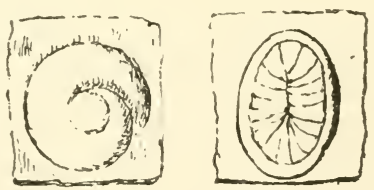

FIG. I3.-Arenicolites (Spiroscolex) spirales (Billings) and Aspidella tenanovica (Billings), Signal Hill Series, Newfoundland. 



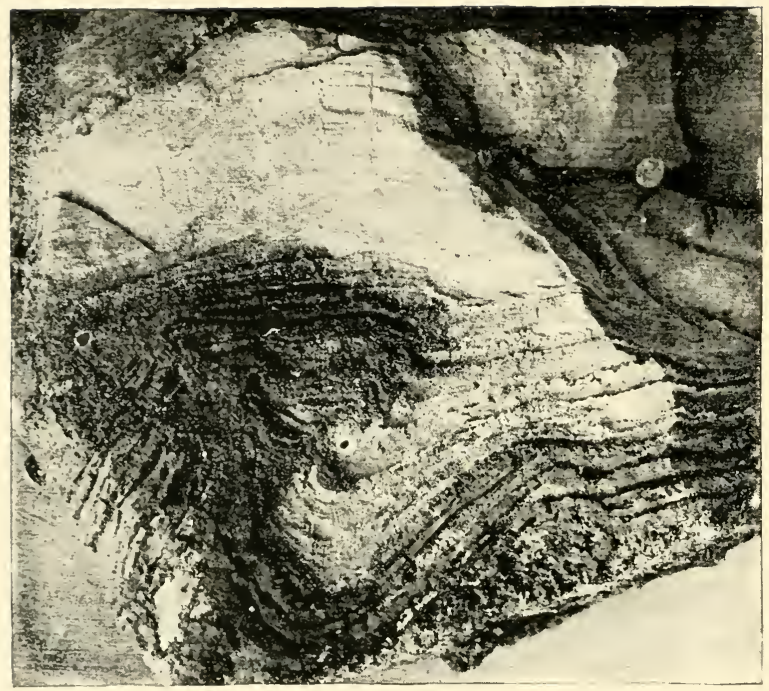

FIG. I4. - Fragment of Crypiozoon, Grand Cañon, Arizona.

Photograph from a specimen presented by $\mathrm{Dr}$ Walcott to the Peter Redpath Museum. 
Colorado Cañon in the Western United States, Walcott has found a small roundish shell of uncertain affinities, ${ }^{1}$ a species of Hyolithes, probably a swimming sea-snail or Pteropod, a small fragment which may possibly have belonged to a Trilobite, and some laminated forms which, if organic, are related to the Cryptozoon already mentioned (Fig. I4).

The Kewenian series of Lake Superior has yielded no fossils, but the pipestone beds of Minnesota, supposed to be about the same age, have afforded a small bivalve shell allied to Lingula ; ${ }^{2}$ and the black shales of the head of Lake Superior contain some impressions supposed to be trails of animals. $^{3}$

It has been a question whether the beds above referred to should be regarded as a downward continuation of the Cambrian, or as the upper part of an older system. Matthew, whose opinion on such a subject is of the highest authority, regards them as a distinct system, but as belonging, with the Cambrian, to the great Palæozoic Period. Van

1 Discinoid or Patelloid.

${ }^{2}$ Winchell.

${ }^{3}$ Selwyn and Matthew. 
Hise, and some other United States authorities, would separate them even from the Palæozoic, and unite them with the underlying Huronian, as representing a "Proterozoic" or "Algonkian" Period. This is merely a matter of classification, necessarily more or less arbitrary; but I believe the facts to be stated subsequently show that it will be best to unite the Etcheminian and its equivalents with the Palæozoic, and to place the groups lower than this in one great division, equivalent to Palæozoic, and for which many years ago I proposed the name "Eozoic," or that of the Dawn of Life.

Having thus hastily glanced at the slender fauna of the rocks immediately below the Cambrian, we may now proceed to inquire a little more in detail into its true value and import as leading toward the beginning of life. I have already referred to the apparently sudden drop in the number of groups and of species below the base of the Cambrian, and have hinted that this may be an effect of temporary local conditions of deposit or of defective information. Another fact that strikes us is the diverse and miscellaneous character of the fossils that remain to us; and this would suggest that we are either dealing with a mere handful picked at random, as it were, 
out of a richer fauna, or that in the beginning of things the gaps and missing links between different forms of life were even more pronounced than at present. This, however, would be likely to occur if the plan of creation was to represent at first different types, with few forms in each; to produce, in short, a sort of type collection representing the whole range of organization by a few characteristic things rather than to give a complete series, with all the intermediate connections. Such a mode of introduction of life is not a priori improbable, however at variance with some prevalent hypotheses.

Beginning with the higher Invertebrates, we must not conclude that we have altogether lost the Trilobites. The fragments referred to this group may represent at least a few species, and it would be very interesting to know more of these as to their relations to their successors, and whether they are tending to lower or more embryonic forms. The bivalve Crustaceans (Ostracods) may be regarded as inferior in rank to the Trilobites, but are still very complex, and specialized animals and a specimen silicified in such a manner as to show the interior organs testified that, as far back as the Carboniferous at least, these creatures were as highly organized as 
at present, ${ }^{1}$ while their generally larger size in the earlier formations tends to show that they have rather been degenerating in the lapse of geological time.

In regard to the Sea-worms, the burrows, castings, and trails found in the pre-Cambrian beds are scarcely, if at all, different from those now seen on sandy and muddy shores, and would seem to indicate that these highly organized and very sensitive and active creatures swarmed in the muddy bottom of the pre-Cambrian Sea, and lived in the same way as at present. It is impossible, however, to know anything of the internal structures of these creatures, but the marks left by their bristle-bearing feet seem to indicate that some of them at least belong to the higher group of Sea-centipedes, creatures rivalling the Crustaceans in complexity of organization, and near to them in plan of structure, though at present usually widely separated from them in current systems of classification. In the Ordovician system, next above the Cambrian, Hinde has found many curiously formed jaws of animals of this kind,

1 Palcocypris Edwardsi, Brougniart, Coal Formation of St. Etienne, France. 
which show at least that their alimentary arrangements were similar to those now in force. If any of the problematical "Conodonts" discovered by Pander in the Cambrian of Russia belonged to marine worms, this inference would be extended back to the Lower Cambrian, so that if the evidence of structure anywhere remains we may hope to find that the pre-Cambrian worms were not inferior to their more modern successors, perhaps even that in this early period, when they probably played a more important part in nature, they were of higher organization than in later times.

The evidence as to pre-Cambrian mollusks, so far as it goes, is even more curious. The little shell called Volborthella, so far as can be judged from its form and internal structure, is a miniature representative of these straight Nautili, the Orthoceratites of the Ordovician and later Palæozoic rocks; and no one doubts that these latter belong to the highest class of the Mollusks, a class approaching in the development of nerve system and sensory organs to the Vertebrates themselves. This tiny member of the great class of Cuttle-fishes may perhaps have been more nearly allied to the modern Spirula than to the Nautilus. In any case, if, as seems altogether 
probable it was, a mollusk, it must have been one of advanced type, and with a highly complex structure, as well as the singular apparatus for flotation implied in a chambered shell with a siphuncle.

Next to this among these primitive Mollusks are straight and spiral shells representing those delicate and beautiful animals of the modern seas, the Pteropods, or wing-footed Sea-snails, beautiful and graceful creatures, the butterflies of the sea, and moving in the water with the greatest ease and beauty by the aid of membranous fins, or wings, sometimes brightly coloured. These creatures abound in all latitudes in the modern ocean, and their delicate shells sometimes accumulate in beds of "Pteropod sand." They very early entered on the arena of marine life, and have continued to this day.

We miss here the two great Molluscan groups of the creeping Sea-snails like the limpet and whelk, and of the ordinary bivalves like the oyster and cockle. Both are present in the lowest Cambrian, though in small numbers compared with their present abundance. Possibly they had not yet appeared in the Etcheminian Sea, though the muddy and sandy bottoms, evidenced by its slates and 
sandstones, would seem to have afforded favourable habitats, and warrant the expectation that species may yet be found.

The case was different with the little group of the Lamp-shells, or Brachiopods. These creatures, somewhat resembling the ordinary bivalves in their shelly coverings, were very dissimilar in their internal structure, and once settled on the bottom they were attached for life, not having even the limited means of locomotion possessed by the Sea-snails and common bivalves. They collected their food wholly by means of currents of water produced by cilia, or movable threads, on arms or processes within their shells. In this they resembled the young or embryo stages of some of the more ordinary Mollusks, though they are so remote from these in their adult condition that they have usually been placed in a distinct class, and some naturalists have thought it best to separate them from the Mollusks altogether. Their history is peculiar. Coming into existence at a very early date, they became very abundant in early Palæozoic times, then gradually gave place to the ordinary bivalves, and in the modern seas are represented by very few species. Yet while in the middle period of their history they 
are represented by very many peculiar specific and generic forms. Some of the earliest types, like Obolus and Lingula, persist very long, and the latter has continued without change from the Early Cambrian to the Modern period.

The great group of the Sea-stars and Sea-urchins appears only in a few of its lower forms, and seems to be the only class represented by embryonic types. The coral animals are absent, so far as known. The Jelly-fishes and their allies cannot be preserved as fossils, but some peculiar markings, at one time regarded as plants, are now supposed to be trails made by the tentacles of creatures of this kind moving over muddy bottoms. A few spicules indicate Sponges, and the ubiquitous groups of the marine Protozoa, the Foraminifera and the Radiolaunus, are represented by shells scarcely distinguishable from those of modern species. The great and peculiar forms represented at this early time by Cryptozoon and its allies seem long ago to have perished, and we shall have to return to them in a later stage of our inquiry.

To sum up the little that we know of this earliest Palæozoic life:-It was perfect of its kind, equally pregnant with evidences of design, and of 
the nicest and most delicate contrivance as the animal life of any later time, and it presupposed vegetable life and multitudes of minute organic beings altogether unknown to us to nourish the creatures we do know. As an example of this, a little Brachiopod or sponge nourished by the currents produced by its cilia, or a Jelly-fish gathering food by its thread-like tentacles, or a Globigerina selecting its nourishment by its delicate gelatinous pseudopods, required an ocean swarming with minute forms of life, which probably can never be known to us, but every one of which must have been an inscrutable miracle of organization and vital function.

Lastly, with reference to our present subject, the Etcheminian fossils carry life backward one whole great period earlier than the Lower Cambrian, and appear to indicate that we are approaching a beginning of living things in the Palæozoic world. Much no doubt remains to be discovered, but it would seem that any future discoveries must fail to negative this conclusion.

\section{The Huronian.}

In whatever way the rocks immediately below the Cambrian may be classified, it is certain that 
the next system in descending order is that to which Logan long ago gave the name Huronian, from its development on Lake Huron ${ }^{1}$ - $a$ name to which it is still entitled, though there may, perhaps, be some grounds for dividing it into an upper and lower member. ${ }^{2}$ To this sub-division, however, we need not for the present give any special attention. In the typical area of Lake Huron the Huronian consists of quartzites, which are merely hardened sandstones, of slates which are muddy or volcanic-ash beds, of conglomerates or pebble-rocks, and of coarse earthy limestone. With these rocks are deposits of igneous material which represent contemporary volcanic eruptions. In other districts, as in New Brunswick, Newfoundland, etc., the beds have been considerably altered, and are locally more mixed with igneous products. The physical picture pre-

1 Dr. G. M. Dawson, F.R.S., the present Director of the Geological Survey of Canada, whose judgment in this matter should be of the highest value, holds that the original simple arrangement of Logan still holds, notwithstanding the multitude of new names proposed by the Western Geologists of the United States.

${ }^{2}$ Van Hise, "Pre-Cambrian Rocks of North America." Comptes Rendus, 5th Session International Geol. Congress 1891, p. 134. Also "Report U.S. Geol. Survey, I895." 
sented to us by the Huronian is that of a shore deposit, formed under circumstances in which beds of pebbles and sand were intermixed with the products of neighbouring volcanoes. Such a formation is not likely to afford fossils in any considerable number and variety, even if deposited at a time of
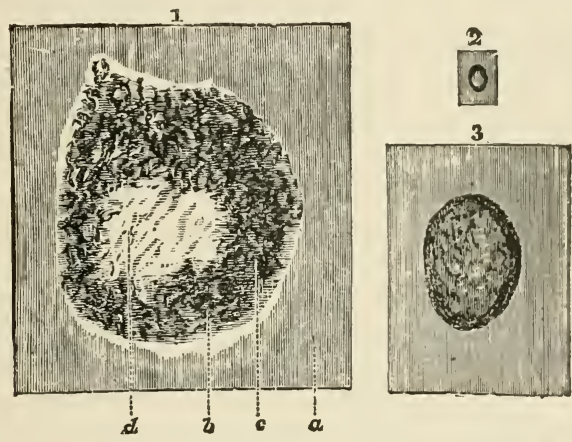

Fig. 15.-Annelid Burrows, Hastings Series, Madoc.

I. Transverse section of Worm-burrow-magnified, as a transparent object. (a) Calcareo-silicious rock. (b) Space filled with calcareous spar. (c) Sand agglutinated and stained black. (d) Sand less agglutinated and uncoloured. 2. Transverse section of Worm-burrow on weathered surface, natural size. 3. The same, magnified.

abundant marine life. It is therefore not wonderful that we find little evidence of living beings in the Huronian. In Canada I can point to nothing of this kind, except a few cylindrical burrows, probably of worms (Fig. I5), and spicules possibly of silicious sponges, which occur in nodules of chert in the limestones, traces of laminated forms like 
Cryptozoon or Eozoon (Fig. I7), and minute carbonaceous fragments which may be debris of seaweeds or Zoophytes. In rocks of similar age in the United States, Gresley has recently discovered worm-burrows, and in Brittany there are quartzite beds in which Barrois and Cayeux believe that

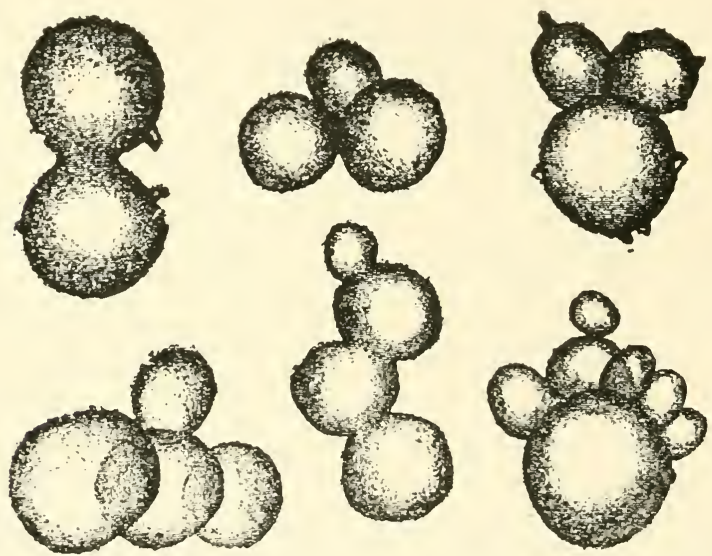

FIG. 16.-Casts of Foraminifera, from the Huronian of Brittany. (After Cayeux.)

Compare with Globigerinæ on Fig. 12 and Archæospherinæ, Figs. 50-54.

they have found tests of Radiolarians, Foraminifera and spicules of sponges, but their organic nature has been denied by Rauff, of Bonn. The casts of Foraminifera, however, at least appear to be organic (Fig. 16), and it is quite likely that Cayeux may be 


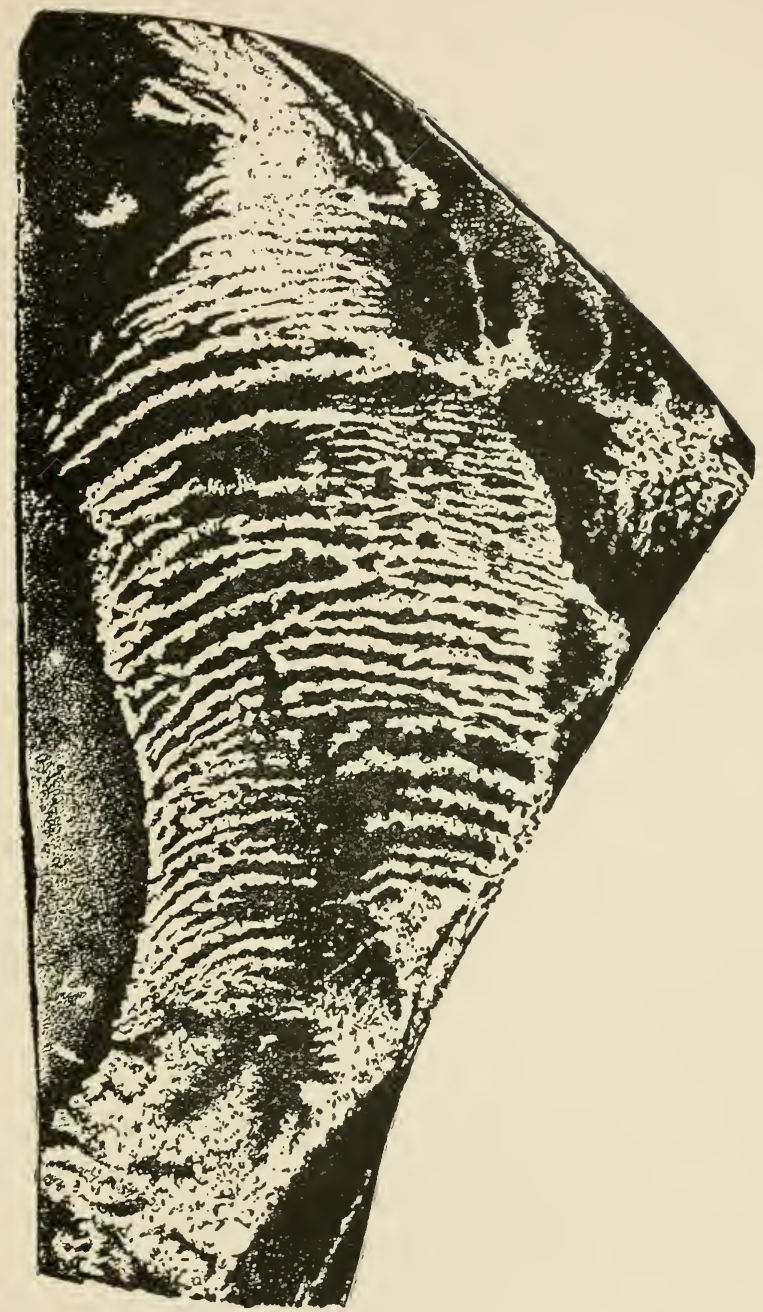

FIG. 17.-Cryptozoon or Eozoon from the Hastings Series, Tudor, Ontario (natural size).

From a specimen collected by the late Mr. Vennor, and now in the collection of the Geological Survey, Ottawa. (See also Frontispiece and figure of Eozoon Baz'aricum, p. 213.) 

able to verify his Radiolarians and sponges as well. Matthew's observations in New Brunswick in any case establish their probability. Gümbel also recognises a species of Eozoon in the equivalent rocks of Bavaria (see p. 213).

It is evident that here we have approached the limit of the higher forms of marine invertebrate life, having as yet nothing to show except worms and Protozoa. It is to be observed, however, that there may be somewhere Huronian deposits formed in deep and quiet waters, which may give better results, and that the unconformity between the Huronian and overlying Kewenian may indicate a lapse of time, of which monuments may yet be found.

\section{The Laurentian.}

Last of all we have the widely distributed Laurentian system of Logan, the oldest known to geologists, and.which with the Huronian constitutes the great Archæan group of formations of Dana and others. In its lowest part this consists entirely of the stratified granitic rock known as gneiss, interbedded in some places with dark-coloured crystalline rocks or schists. This may be a part of the firstformed crust of our globe, produced under conditions 
different from those of any later rocks, and incompatible with the existence of life. The upper part of the Laurentian system, however, known in Canada as the "Grenville Series," shows evidence of ordinary marine deposition in quiet waters, which may have been not unfavourable to the lower forms of marine life; and though its beds have been greatly changed by heat and pressure, we can still to some extent realize the conditions of a time of comparative quiescence intervening between the underlying Lower Laurentian and the succeeding Huronian. This part of the system still contains gneisses, bedded diorites, and other rocks which may have been volcanic; but it has also quartzites and quartzose gneisses which must have been sandstones or shales, thick limestones, beds of carbon now in the state of graphite or plumbago, and large beds of iron ore. Such rocks were in all succeeding formations produced under water and by accumulations of the remains of plants and the hard parts of animals, in strictly sedimentary beds, usually formed slowly and without mechanical disturbance. Hence we may infer that aquatic life at least existed in this early period, and as there must have been land and water, shallows and deep 
seas, there may have been scope for various kinds of living beings. The Grenville period is, however, separated from the succeeding Huronian by a great interval, occupied mainly by volcanic ejections and earth-movements; so that our Grenville series, if it contains organic remains, may be supposed to afford species differing from those of the Huronian, and to form a sort of oasis in the desert of the early pre-Cambrian world. We find that the limestones of this age actually contain remains supposed to be of animal origin. They were first found in Canada, which contains the largest and best exposed area of these rocks in the world, and were brought under the notice of geologists by the late Sir William E. Logan, the first director of the Geological Survey of that country.

In anticipation of details to be given later, the story of this discovery and its announcement may here be given in brief.

As early as I 858, Sir William Logan had begun to suspect that certain laminated bodies found in the Laurentian limestones of the Grenville series might be of organic origin. The points which struck him were these: They differed from any known laminated concretions; they resembled the "Stromato- 
poræ" or layer-corals of the lower Palæozoic rocks next in succession to the Laurentian and Huronian; the forms were similar in all the specimens, while the mineralizing substances were different; they were found only in the limestone, and specially in one of the three great beds known in the formation, the upper limestone of the Grenville system. He exhibited specimens, and mentioned these probabilities at the meeting of the American Association in I859. In I 862 it was suggested to Logan that the microscopic structure of some of the best preserved examples should be studied, and slices were accordingly prepared and submitted to the writer for examination. They revealed in the calcareous laminæ of the specimens complicated systems of canals or tubes filled with mineral matter, which appeared to be similar to those that Carpenter had recognised in the thickened parts of the shells of modern Foraminifera. This clew being followed, large numbers of slices of the supposed fossils and of the containing limestone and of similar limestones from other parts of the world were examined.

The writer also visited the localities of "Eozoon," and studied its mode of occurrence in situ. The facts ascertained were communicated to the Geo- 
logical Society of London, the name "Eozoon Canadense" being proposed for the species. Its description was accompanied by a paper on the geological conditions by Logan, and one on the chemical conditions by Sterry Hunt, while supplementary notes were added by the late Dr. Carpenter and Professor T. Rupert Jones. Thus launched on the scientific world, "Eozoon" at once became a fertile subject of discussion, and volumes of more or less controversial literature have appeared respecting it. It still has its friends and opponents, and this may long continue, as so few scientific men are sufficiently acquainted on the one hand with the possibilities and conditions of the preservation of fossils in crystalline rocks, and on the other hand with the structures of modern "Protozoa." Thus, few are in a position to form an independent judgment, and "Eozoon" has met with some scepticism on the part both of biological and mineralogical specialists.

To aid us in forming an opinion, it will be necessary to consider the oldest known strata of the earth's crust, and the evidence which they afford of the condition of the world when they were deposited. As preliminary to this, we may look at the following table of pre-Camhrian formations in Canada. 
SUCCESSION OF PRE-CAMBRIAN ROCKS IN CANADA, AS UNDERSTOOD UP TO 1896.

(In descending order.)

ETCHEMINIAN in New Brunswick, Kewenian or Upper Copper-bearing Series of Lake Superior, Signal Hill Series of Newfoundland. Chuar, and Grand Cañon rocks of Colorado, etc.

Red and greenish Sandstones and Shales, Conglomerates, Igneous Outflows and Ash-rocks. Bivalve Crustacea, Mollusks, Worms, Sponges, Cystideans, Zoophytes, Protozoa, Cryptozoon.

(Unconformity.)

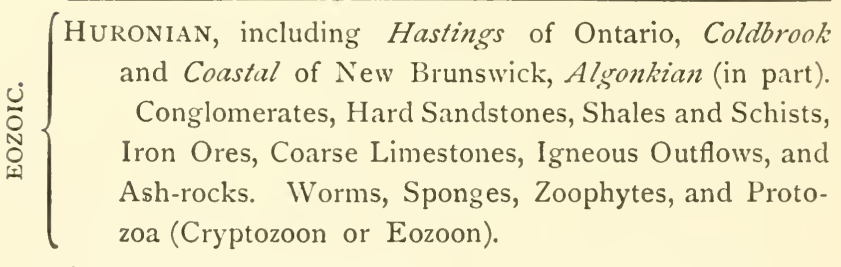

(Unconformity [?])

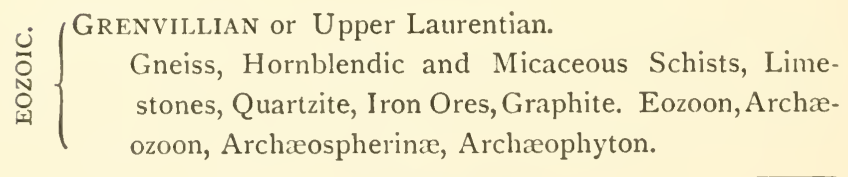

\section{Unconformity.}

\footnotetext{
穴 $\{$ ARCHÆAN or Lower Laurentian.

Gneiss, Hornblende Schists, with many igneous or igneo-aqueous intrusions.
} 
THE FOUNDATIONS OF THE CONTINENTS, AND THEIR GENERAL TESTIMONY AS TO LIFE 



\section{IV}

THE FOUNDATIONS OF THE CONTINENTS, AND THEIR GENERAL TESTIMONY AS TO LIFE

THAT the reader may be enabled better to 1 understand the relation of the old foundations or pillars of the earth to the beginning of life, and the preservation of the remains of the earliest animals, it may be well to reverse the method we have hitherto followed, and to present a theoretical or ideal historical sketch of the early history of the earth, beginning with that stage in which it may be supposed to have been a liquid mass, considerably larger than it is at present, and intensely heated, and surrounded by a vast vaporous envelope composed of all the substances capable of being resolved by its heat into a gaseous condition- $\mathrm{a}$ smooth and shining spheroid, invested with an enormous atmosphere.

In such a condition its denser materials, such as the heavier metals, would settle toward the centre, and the surface would consist of lighter material 
composed of the less dense and more oxidizable substances combined with oxygen, and similar in character and appearance to the slag which forms on the surface of some ores in the process of smelting. Of this slaggy material there might, however, be different layers more or less dense in proceeding from the interior to the surface. This molten surface would, of course, radiate heat into space; and as it would naturally consist of the least fusible matters, these would begin to form a solid crust. We may imagine this crust at first to be smooth and unbroken, though such a condition could scarcely exist for any length of time, as the hardened crust would certainly be disturbed by ascending currents from within, and by tidal movements without. Still, it might remain for ages as a spheroidal crust, presenting little difference of elevation or depression in comparison with its extent. When it became sufficiently thick and cool to allow water to lie on its surface, new changes would begin. The water so condensed would be charged with acid substances which would begin to corrode the rocky surface. Penetrating into crevices and flashing into steam as it reached the heated interior, it would blow up masses and fragments of stone, and 
would perhaps force out and cause to flow over the surface beds of molten material from below the crust, and differing somewhat from it in their composition. All this aqueous work would accelerate the cooling and thickening of the crust, and at length a universal or almost universal heated ocean would envelope the globe, and so far as its surface was concerned, the reign of water would replace that of fire. We may pause here to consider the probable nature of the earth's crust in this condition.

The substance most likely to predominate would be silica or quartz, one of the lighter and most infusible materials of the crust; but which, heated in contact with alumina, lime, potash, and other earths and alkalis, forms fusible slags, enamels and glasses. One of these, composed of silica, alumina, and potash, or soda, was long ago named by the German miners felspar, a name which it still retains, though now several distinct kinds of it are distinguished by different names. Another is a compound of silica with magnesia and lime, forming the mineral known as Amphibole or Hornblende, and by several other names, according to its colour and crystalline form. In many deep- 
seated rocks these minerals are formed together, and having crystallized out separately give a spotted and granular character to the mass. Naturally colourless, all these minerals, and especially the felspar and hornblende, are liable to be coloured with different oxides of iron, the felspar usually taking a reddish, and the hornblende a greenish or blackish hue. Now, if we examine a fragment of the oldest or fundamental gneiss or granite, we shall see glassy grains of quartz, reddish or white flat-surfaced crystals of felspar, and darkcoloured prisms of hornblende. When destitute of any arrangement in layers, the rock is granite; when arranged more or less in flakes or laminæ, it is gneiss, the structure of which may arise either from its having been formed in successive beds, or from its having been flattened or drawn out by pressure. These structures can be seen more or less distinctly in any ordinary coarse-grained granite, or with the lens or microscope in finer varieties.

The Lower Laurentian rocks of our section consist essentially of the materials above described, with a vast variety in the proportions and arrangements of the constituent minerals. There is, there- 
fore, nothing to prevent us from supposing that these rocks are really remains of the lower portions of the original crust which first formed on the surface of our cooling planet, though the details of their consolidation and the possible interactions of heat and heated water may admit of much discussion and difference of opinion.

But after the formation of a crust and its covering in whole or in part with heated water, other changes must occur, in order to fit the earth for the abode of life. These proceeded from the tensions set up by the contraction and expansion of the interior heated nucleus and the solid crusta complicated and difficult question, when we consider its laws and their mode of operation, but which resulted in the folding and fracturing of the crust along long lines which are parts of great circles of the earth, running in N.E. and S.IW. and N.W. and S.E. directions; and these ridges, which in the earliest Archæan period must have attained to great height and very rugged outlines, formed the first rudiments of our mountain chains and continents. Those constituting the Laurentian nucleus of North America-a very simply outlined continent-form a case in point (Fig. I8). 
The elevation of these mountain ridges forced the waters to recede into the lower levels. As the old psalm of creation has it,-

"The mountains ascend, the valleys descend into the place Thou hast founded for them,"

and so sea-basins and land were produced.

Milton merely paraphrases this when he says,-

"The mountains huge appear

Emergent, and their broad, bare backs upheave

Into the clouds; their tops ascend the sky.

So high as heaved the tumid hills, so low

Down sunk a hollow bottom wide and deep,

Capacious bed of waters."

Englishmen have been accused of taking their ideas of creation from Milton rather than from nature or the Bible. Milton had not the guidance of modern geology. His cosmology is entirely that of a close student of the Biblical narrative of creation. He is in many respects the best commentator on the early chapters of Genesis, because he had a very clear conception of the mind of the writer, and the power of expressing the ideas he derived from the old record. For the same reason he is the greatest bard of creation and primitive man, and surprisingly accurate and true to nature. 
Then began the great processes of denudation and sedimentation to which we owe the succeeding rock formations. The rains descended on the mountain steeps, and washed the decaying rocks as sand, gravel and mud into the rivers and the

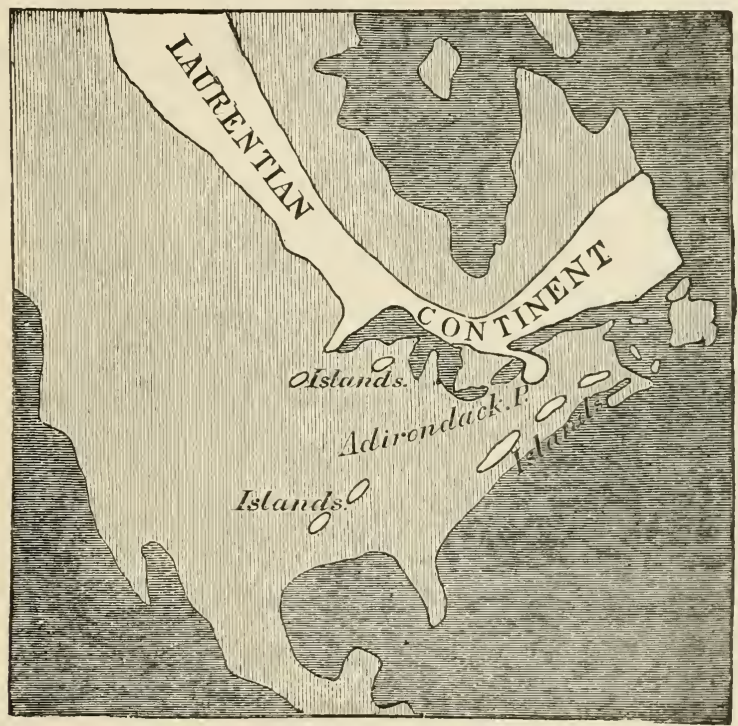

FIG. 18.-Map of Laurentian, North America. Showing the protaxis or nucleus of the continent.

sea. The sea itself raged against the coasts, and cut deeply into their softer parts; and all the detritus thus produced by atmospheric and marine denudation was spread out by the tides and currents in the bed of the ocean, and its gulfs and 
seas, forming the first aqueous deposits, while the original land must have been correspondingly reduced.

The sea might still be warm, and it held in solution or suspension somewhat different substances from those now present in it, and the land was at first a mere chaos of rocky crags and pinnacles. But so soon as the temperature of the waters fell somewhat below the boiling point, and as even a little soil formed in the valleys and hollows of the land, there was scope for life, provided that its germs could be introduced.

On a small scale there was something of this same kind in the sea and land of Java, after the great eruption of Krakatoa, in I883. The bare and arid mountain left after the eruption, began, in the course of a year, to be occupied by low forms of vegetable life, gradually followed by others, and verdure was soon restored. The once thickly peopled sea-bottom, so prolific of life in these warm seas, but buried under many feet of volcanic ashes and stones, soon began to be re-peopled, and is now probably as populous as before. But in this case there were plenty of spores of lichens, mosses, and other humble plants to be wafted to the desolate 
cone, and multitudes of eggs and free-swimming germs of hundreds of kinds of marine animals to re-people the sea-bottom. Whence were such things to come from to occupy the old Archæan hills and sea-basins? and all our knowledge of nature gives us no answer to the question, except that a creative power must have intervened; but in what manner we know not. That this actually occurred, we can, however, be assured by the next succeeding geological formation. We have seen that the granitic and gneissic ridges could furnish pebbles, sand, and clay, and these once deposited in the sea-bottom could be hardened into conglomerate, sandstone and slate. But beside these we have in the next succeeding or Upper Laurentian formation rocks of a very different character. We have great beds of limestone and iron ore, and deposits, of carbon or coaly matter, now in the peculiar state of graphite or plumbago, and it is necessary for us to inquire how these could originate independently of life. In modern seas limestone is forming in coral reefs, in shell beds, and in oceanic chalky ooze composed of minute microscopic shells; but only in rare and exceptional instances is it formed in any other 
way; and when we interrogate the old limestones
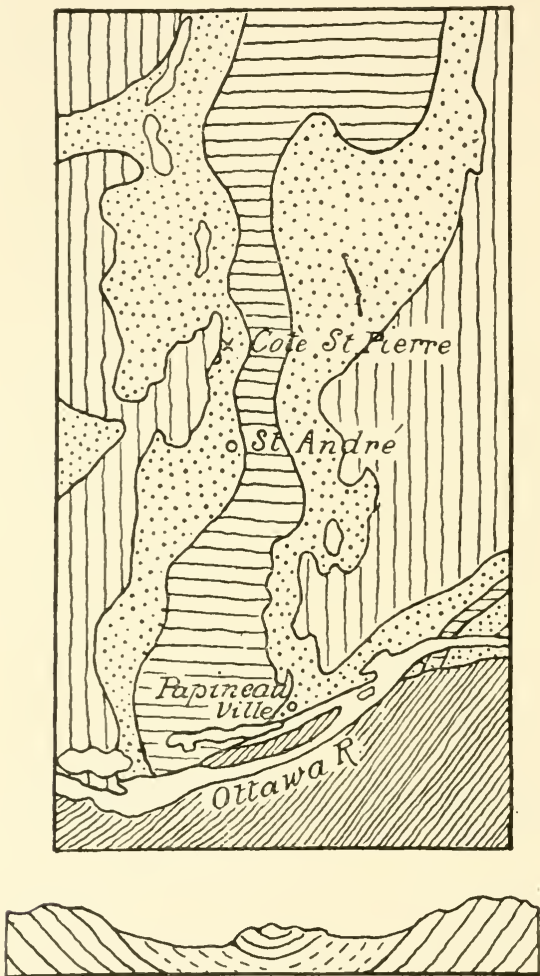

FIG. 19. - Distribution of Grenville Lamestone $2 n$ the wistrict north of Papineauville, with section showing supposed arrangement of the beds.

Scale of Map 7 miles to one inch. See also Dr. Bonney's paper, Geol. Mag., July, 1895 .

Dotted area: Limestone. Horizontal lines: Upper gneiss (fourth gneiss of Logan). Vertical lines: Lower gneiss (third gneiss of Logan). Diagonal lines: Overlying Cambrian and Cambro-Silurian (Ordovician). See also Fig.raA.)

and marbles which form parts of the land, they 
give us evidence that they also are made up of calcareous skeletons of marine animals or fragments of these. Now when we find in the Grenvillian series, the first oceanic group of beds known to us, great and widely extended limestones, thousands of feet in thickness, and rivalling in magnitude those of any succeeding period, we naturally infer that marine life was at work. No doubt the primitive sea contained more lime and magnesia than the present ocean holds in solution; but while this might locally favour the accumulation of inorganic limestones, it cannot account for so great and extensive deposits. On the other hand, a sea rich in lime would have afforded the greatest facilities for the growth of those marine plants which accumulate lime, and through these for the nutrition of animals forming calcareous shells or corals. Thus we have presumptive evidence that there must have been in the Upper Laurentian sea something corresponding to our coral reefs and shell-beds, whatever this something may have been.

These limestones, however, demand more particular notice (Fig. 19).

One of the beds measured by the officers of the Geological Survey is stated to be I,500 feet in 
thickness, another is I,250 feet thick, and a third 750 feet; making an aggregate of 3,500 feet. $^{1}$ These beds may be traced, with more or less interruption, for hundreds of miles. Whatever the origin of such limestones, it is plain that they indicate causes equal in extent, and comparable in power and duration, with those which have produced the greatest limestones of the later geological periods. Now, in later formations, limestone is usually an organic rock, accumulated by the slow gathering from the sea-water, or its plants, of calcareous matter, by corals, foraminifera, or shell-fish, and the deposition of their skeletons, either entire or in fragments on the sea-bottom. The most friable chalk and the most crystalline limestones have alike been formed in this way. We know of no reason why it should be different in the Laurentian period. When, therefore, we find great and conformable beds of limestone, such as those described by Sir William Logan in the Laurentian of Canada, we naturally imagine a quiet sea-bottom, in which multitudes of animals of humble organization were accumulating limestone in their hard parts, and depositing this in gradually increasing

1 Logan : "Geology of Canada," p. 45. 
thickness from age to age. Any attempts to account otherwise for these thick and greatly extended beds, regularly interstratified with other deposits, have so far been failures, and have arisen either from a want of comprehension of the nature and magnitude of the appearances to be explained, or from the error of mistaking the true bedded limestones for veins of calcareous spar.

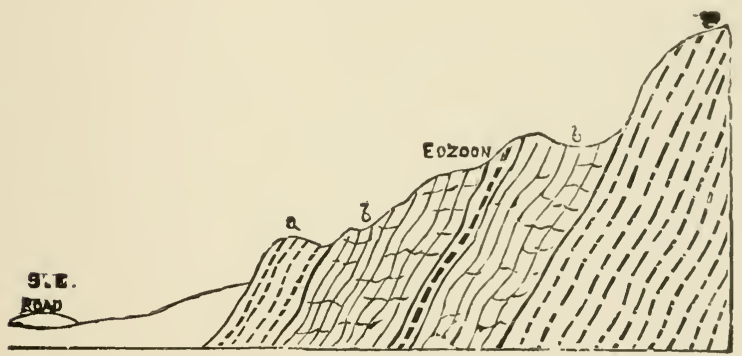

FIg. 19A.--Attitude of Limestone at Côte St. Pierre (see Map, p. 88).

(a) Gneiss band in the Limestone. (b) Limestone with Eozoon.

(c) Diorite and Gneiss.

Again, in the original molten world, it seems likely that most of the carbon present-at least, at the surface - was in the atmosphere in the gaseous form of carbon dioxide. This might be dissolved by the rain and other waters; but we know in the modern world no agency which can decompose this compound and reduce it to ordinary 
carbon or coal, except that of living plants, which are always carrying on this function to an enormous extent. We know that all our great beds of coal and peaty matter are composed of the remains of plants which took their carbon from the air and the waters in past times. We also know that this coaly vegetable matter may, under the influence of heat and pressure, when buried in the earth, be converted into anthracite and into graphite, and even into diamond. It is true that an eminent French chemist ${ }^{1}$ has shown that graphite and hydrocarbons may be produced from some of the metallic compounds of carbon which may have been formed under intense heat in the interior of the earth, by the subsequent action of water on such compounds; but there is nothing to show that this can have occurred naturally, unless in very exceptional cases. Now in the Grenvillian system in Canada there is not only a vast quantity of carbon diffused through the limestones, and filling fissures in other rocks, into which it seems to have been originally introduced as liquid bitumen, but also in definite beds associated with earthy matter,

${ }^{1}$ Henri Moissan, “Proceedings Royal Society," June, I 896. 
and sometimes ten to twelve feet thick. The occurrence of this large amount of carbon warrants us in supposing that it represents a vast vegetable growth, either on the land or in the sea, or both.

In like manner, in later geological periods, berls of iron ore are generally accumulated as a consequence of the solvent action of acids produced by vegetable decay, as in the clay ironstones of the coal formation and the bog iron ores of later times. Thus the beds of magnetic iron occurring in the Upper Laurentian may be taken as evidences, not of vegetable accumulation, but of vegetable decay.

May not also the great quantity of calcium phosphate mined in the Grenville series in Canada, indicate, as similar accumulations do in later formations, the presence of organisms having skeletons of bone earth?

With reference to the carbon and iron ore of the Grenville series, I may quote the following from a paper published in the Journal of the Geological Society of London in I870 :-

"The quantity of graphite in the Upper Laurentian series is enormous. In a recent visit to the township of Buckingham, on the Ottawa River, I examined a band of limestone believed to be a 
continuation of that described by Sir W. E. Logan as the Green Lake Limestone. It was estimated to amount, with some thin interstratified bands of gneiss, to a thickness of 600 feet or more, and was found to be filled with disseminated crystals of graphite and veins of the mineral to such an extent as to constitute in some places one-fourth of the whole; and making every allowance for the poorer portions, this band cannot contain in all a less vertical thickness of pure graphite than from twenty to thirty feet. In the adjoining township of Lochaber Sir IV. E. Logan notices a band from twentyfive to thirty feet thick, reticulated with graphite veins to such an extent as to be mined with profit for the mineral. At another place in the same district a bed of graphite from ten to twelve feet thick, and yielding twenty per cent. of the pure material, is worked. When it is considered that graphite occurs in similar abundance at several other horizons, in beds of limestone which have been ascertained by Sir IV. E. Logan to have an aggregate thickness of 3,500 feet, it is scarcely an exaggeration to maintain that the quantity of carbon in the Laurentian is equal to that in similar areas of the Carboniferous system. It is also to 
be observed that an immense area in Canada appears to be occupied by these graphitic and Eozoon limestones, and that rich graphitic deposits exist in the continuation of this system in the State of New York; while in rocks believed to be of this age near St. John, New Brunswick, there is a very thick bed of graphitic limestone, and associated with it three regular beds of graphite, having an aggregate thickness of about five feet. ${ }^{1}$

"It may fairly be assumed that in the present world, and in those geological periods with whose organic remains we are more familiar than with those of the Laurentian, there is no other source of unoxidized carbon in rocks than that furnished by organic matter, and that this has obtained its carbon in all cases, in the first instance, from the deoxidation of carbonic acid by living plants. No other source of carbon can, I believe, be imagined in the Laurentian period. We may, however, suppose either that the graphitic matter of the Laurentian has been accumulated in beds like those of coal, or that it has consisted of diffused bituminous

1 Matthew, in Quart. Journ. Geol. Soc., vol. xxi. p. 423. "Acadian Geology," p. 662. 
matter similar to that in more modern bituminous shales and bituminous and oil-bearing limestones. The beds of graphite near St. John, some of those in the gneiss at Ticonderoga in New York, and at Lochaber and Buckingham and elsewhere in Canada, are so pure and regular that one might fairly compare them with the graphitic coal of Rhode Island. These instances, however, are exceptional, and the greater part of the disseminated and vein graphite might rather be compared in its mode of occurrence to the bituminous matter in bituminous shales and limestones.

"IVe may compare the disseminated graphite to that which we find in those districts of Canada in which Silurian and Devonian bituminous shales and limestones have been metamorphosed and converted into graphitic rocks not dissimilar to those in the less altered portions of the Laurentian. ${ }^{1}$ In like manner it seems probable that the numerous reticulating veins of graphite may have been formed by the segregation of bituminous matter into fissures and planes of least resistance, in the manner in

${ }^{1}$ Granby, Melbourne, Owl's Head, etc., "Geology of Canada," I 863 , p. 599. 
which such veins occur in modern bituminous limestones and shales. Such bituminous veins occur in the Lower Carboniferous limestone and shale of Dorchester and Hillsborough, New Brunswick, with an arrangement very similar to that of the veins of graphite; and in the Quebec rocks of Point Levi, veins attaining to a thickness of more than a foot are filled with a coaly matter having a transverse columnar structure, and regarded by Logan and Hunt as an altered bitumen. These Palæozoic analogies would lead us to infer that the larger part of the Laurentian graphite falls under the second class of deposits above mentioned, and that, if of vegetable origin, the organic matter must have been thoroughly disintegrated and bituminized before it was changed into graphite. This would also give a probability that the vegetation implied was aquatic, or at least that it was accumulated under water.

"Dr. Hunt has, however, observed an indication of terrestrial vegetation, or at least of subaërial decay, in the great beds of Laurentian iron ore. These, if formed in the same manner as more modern deposits of this kind, would imply the reducing and solvent action of substances produced in the 
decay of plants. In this case such great ore beds as that of Hull, on the Ottawa, 70 feet thick, or that near Newborough, 200 feet thick, ${ }^{1}$ must represent a corresponding quantity of vegetable matter which has totally disappeared. It may be added that similar demands on vegetable matter as a deoxidizing agent are made by the beds and veins of metallic sulphides of the Laurentian, though some of the latter are no doubt of later date than the Laurentian rocks themselves.

"It would be very desirable to confirm such conclusions as those above deduced by the evidence of actual microscopic structure. It is to be observed, however, that when, in more modern sediments, algæ have been converted into bituminous matter, we cannot ordinarily obtain any structural evidence of the origin of such bitumen, and in the graphitic slates and limestones derived from the metamorphosis of such rocks no organic structure remains. It is true that, in certain bituminous shales and limestones of the Silurian system, shreds of organic tissue can sometimes be detected, and in some cases, as in the Lower Silurian limestone of the

1 "Geology of Canada," I 863. 
La Cloche mountains in Canada, the pores of brachiopodous shells and the cells of corals have been penetrated by black bituminous matter, forming what may be regarded as natural injections, sometimes of much beauty. In correspondence with this, while in some Laurentian graphitic rocks,-as, for instance, in the compact graphite of Clarendon,-the carbon presents a curdled appearance due to segregation, and precisely similar to that of the bitumen in more modern bituminous rocks, I can detect in the graphitic limestones occasional fibrous structures which may be remains of plants, and in some specimens vermicular lines, which I believe to be tubes of Eozoon penetrated by matter once bituminous, but now in the state of graphite.

"When Palæozoic land-plants have been converted into graphite, they sometimes perfectly retain their structure. Mineral charcoal, with structure, exists in the graphitic coal of Rhode Island. The fronds of ferns, with their minutest veins perfect, are preserved in the Devonian shales of St. John, in the state of graphite; and in the same formation there are trunks of Conifers (Dadoxylon ouangondianum) in which the material of the cell-walls has been converted into graphite, while their cavities 
have been filled with calcareous spar and quartz, the finest structures being preserved quite as well as in comparatively unaltered specimens from the coal-formation. ${ }^{1} \quad$ No structures so perfect have as yet been detected in the Laurentian, though in the largest of the three graphitic beds at St. John there appear to be fibrous structures which I believe may indicate the existence of land-plants. This graphite is composed of contorted and slickensided laminæ, much like those of some bituminous shales and coarse coals; and in these there are occasional small pyritous masses which show hollow carbonaceous fibres, in some cases presenting obscure indications of lateral pores. I regard these indications, however, as uncertain; and it is not as yet fully ascertained that these beds at St. John are on the same geological horizon with the Grenville series of Canada, though they certainly underlie the Cambrian series of the St. John or Acadian group, and are separated from it by beds having the character of the Huronian, and thus come, approximately at least, into the same geological position.

1 "Acadian Geology," p. 535. In calcified specimens the structures remain in the graphite after decalcification by an acid. 
"There is thus no absolute impossibility that distinct organic tissues may be found in the Laurentian graphite, if formed from land-plants, more especially if any plants existed at that time having true woody or vascular tissues; but it cannot with certainty be affirmed that such tissues have been found. It is possible, however, that in the Laurentian period the vegetation of the land may have consisted wholly of cellular plants, as, for example, mosses and lichens; and if so, there would be comparatively little hope of the distinct preservation of their forms or tissues, or of our being able to distinguish the remains of land-plants from those of Algæ. The only apparent plant of the Laurentian to which a name has been given, Archcophyton of Britton, from New Jersey, consists of ribbon-like strips, destitute of apparent structure, and which, if they are of vegetable origin, may have belonged to either of the leading divisions of the vegetable kingdom. I have found similar flat frond-like objects in

- the limestone of the Grenville series, at Lachute, in Canada.

"We may sum up these facts and considerations in the following statements:-First, that somewhat obscure traces of organic structure can be detected 
in the Laurentian graphite; secondly, that the general arrangement and microscopic structure of the substance corresponds with that of the carbonaceous and bituminous matters in marine formations of more modern date; thirdly, that if the Laurentian graphite has been derived from vegetable matter. it has only undergone a metamorphosis similar in kind to that which organic matter in metamorphosed sediment of later age has experienced; fourthly, that the association of the graphitic matter with organic limestone, beds of iron ore, and metallic sulphides, greatly strengthens the probability of its vegetable origin; fifthly, that when we consider the immense thickness and extent of the Eozoonal and graphitic limestones and iron ore deposits of the Laurentian, if we admit the organic origin of the limestone and graphite, we must be prepared to believe that the life of that early period, though it may have existed under low forms, was most copiously developed, and that it equalled, perhaps surpassed, in its results, in the way of geological accumulation, that of any subsequent period."

Let us take, in connection with all this, the fact that we are dealing with the deposits of the earlicst o. ean known to us-an ocean warm and abounding 
in the mineral matters suitable for the skeletons of humble animals, and fitted to nourish aquatic plants. The conditions were certainly favourable to an exuberant development of the lower forms of marine
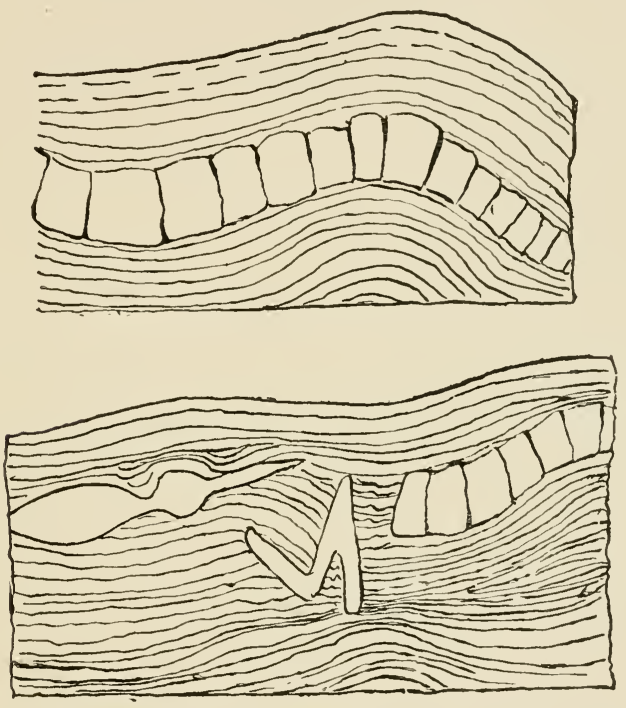

FIGS. 20 and 21.-Bent and dislocated Quartzite, in contorted schists interstratified with Grenville Limestone, near Montebello.

The Quartzites have been broken and displaced, while the schists have been bent and twisted. In the immediate vicinity the same beds may be seen slightly in. clined and undisturbed.

life; and in later times, when such conditions prevail, we generally find that life has been introduced to take advantage of them. The prudent farmer does not usually allow his best pasture to remain 
untenanted with flocks and herds, and the Great Husbandman of nature has, so far as we know, been similarly careful.

I add two sections showing the local disturbances of beds of quartzite and schist associated with the Grenville limestones (Figs. 20 and 2I, page 103). 
PROBABILITIES AS TO LAURENTIAN LIFE, AND CONDITIONS OF ITS PRESERVATION 

PROBABILITIES AS TO LAURENTIAN LIFE, AND CONDITIONS OF ITS PRESERVATION

W have seen that the mineral constitution of
the Upper Laurentian affords evidence that in this age there were already land and water, and that the processes by which the land is being worn down, and its materials deposited on the sea-bottom, were in full operation; while the absence of any evidence of violent wave-action, and the presence of thick deposits of limestone, coaly matter, iron ore, and fine-grained beds of sediment, indicates a time of rest and quiescence. All these conditions were favourable to the presence of life, and we should expect to find in such a period some sign of its commencement.

But here we are met by a formidable difficulty. If the beds of the Grenville series were originally deposits in a quiet sea, they are, as now existing in the old Laurentian hills and valleys, very much changed from their original condition. They have, 
in short, experienced the changes known to geologists by the formidable word metamorphism, whereby they have lost the more obvious characters of ordinary aqueous deposits, and have assumed new and strange forms. Dr. Adams, of Montreal, has taken the pains to collect a number of chemical analyses of the gneisses and schists or crystalline slates of the Grenville series, and finds that, however unlike to more modern shales and clays, they have substantially the same chemical composition. Now if they were originally such shales and clays, it has happened to them that the ingredients of the clays have rearranged themselves in new forms and become crystalline. We are familiar in a small way with such changes when brick clay, over-heated in the kiln, becomes fused into slag or vitrified; and if such slag were allowed to cool very slowly, it would present different kinds of crystalline minerals. We actually see changes of this kind in the substance of bricks which have been long exposed to intense heat in the walls of furnaces. Now in the crust of the earth, very old rocks, buried under newer deposits, and exposed to the heat of the interior molten rocks, experience such changes on a great scale; and there is one kind of influence present in 
the bowels of the earth which we in our experiments cannot easily imitate or understand, namely, the action of superheated water prevented by pressure from escaping as steam, and permeating the whole substance of deposits, which are thus baked at a high temperature in presence of water, instead of being exposed to mere dry heat, as in our kilns and furnaces. The study of the partial changes which have passed on later sediments where in contact with volcanic masses once intensely heated, enables us to understand the greater and more extensive metamorphism of the oldest rocks. Thus a mere mud becomes glorified by metamorphic crystallization into a micaceous schist. We have taken ordinary clay as an example; but under the same processes sand has been converted into a compact quartzite, ordinary limestone into crystalline marble, clay-ironstone into magnetic iron ore, coal into graphite, and lavas or volcanic ashes into hard crystalline granites, gneisses, or pyroxene rocks or hornblendic schists, according to their original composition. There may exist portions of these old rocks which have been exempt from such alteration, but hitherto we have not been able to find them, and they are probably under the ocean bed, or 
deeply buried beneath later rocks, while the parts exposed are precisely those which have by their crumpling and pressure, and the influence of internal heat, become most hardened and altered, and have therefore best resisted denudation. We need not therefore be astonished if any organic remains originally present in such rocks should have perished, or should have been subjected to such changes of composition and form as to have altogether lost their original characters. The searcher for fossils in such rocks has to expect that these can have been preserved only under very rare and exceptional circumstances. We have now to consider what these circumstances are, and for simplicity may suppose that we are endeavouring to discover in a crystalline limestone the remains of animals having a skeleton of limestone, as is the case with most shell-fishes and corals, and with many Protozoa and marine worms. In regard to these, we have to consider what may happen to them when they are imbedded in calcareous marl or ooze, or the limestone which results from the hardening of such materials; and we have to bear in mind that such organisms usually consist of hard, stony walls or partitions, enclosing cavities originally filled with the soft parts 
of the animal which may be supposed to have disappeared by decay before or during the mineralization of its skeleton.

So long as the imbedding mass continues soft and incoherent, shells, corals, etc., can be recovered in a condition similar to that of recent specimens, except that they may have become bleached in colour and brittle in texture, owing to the removal of organic matter intimately associated with the lime, and that their cavities may have been filled with sand or silt washed into them, or with calcite or calcareous spar introduced in solution in water. But if the containing mass has become a hard stone, the material filling the interior of our shell or coral has experienced a similar change; and when we break open the stone, we may obtain the specimen, now hard, solid, and heavy, but still showing more or less of its outer surface and markings, and possibly to some extent also its internal structure when it is sliced and studied under the microscope. But if the whole mass has been metamorphosed, and has become crystalline, the contained fossil and its contents may have experienced a similar change, and may have so coalesced with the containing matrix that it is no longer separable from it. Even in this case, 
however, if the whole is reduced to a thin transparent slice and examined microscopically, some traces may be found of the external and internal limiting lines of the fossil, and even of its minute structures, which often cause it to present an appearance granular,

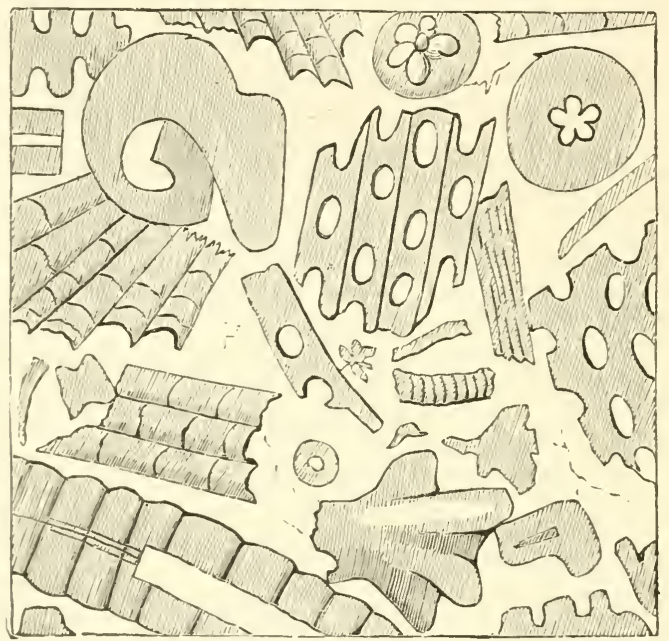

FIG. 22.-Section of "Trenton Limestone" (magnified).

Showing its composition of fragments of calcareous fossils.

cellular, or otherwise different from that of the enclosing matrix. It requires, however, both skill and care to detect organic remains in such circumstances, and they may often escape observation, except when, as in many old crystalline limestones, the fossils are darkened in whole or in part with coaly matter 
derived from the decay of their own organic substance. The crystalline Trenton limestone of Montreal, used there as a building stone, is an excellent example (Fig. 22).

It is otherwise, however, when the calcareous fossils have been filled or injected with some mineral matter different from the matrix, as, for example, silica or some silicate, oxide or sulphide of iron.
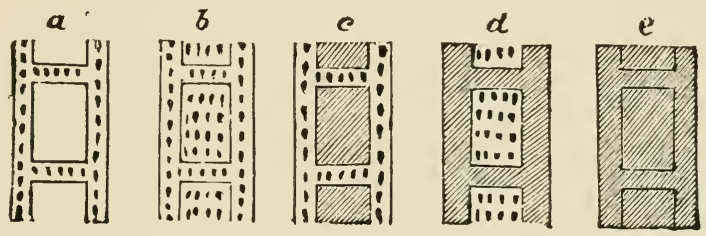

FIG. 23.-Diagram of different States of Fossilization of the Cell of a Tubulate Coral.

(a) Natural condition. (b) Cell filled with calcite. (c) Walls calcite, filling silica. (d) Walls silica, filling calcite. (e) Both walls and calcite silica. All these conditions are found in the fossil corals of the corniferous Limestone of Canada - Middle Permian.

In this case the texture, colour, or hardness of the filling appear different from those of the limestone, and may be seen in a fresh fracture or polished slice; or when the rock is weathered, the hard mineralizing substance may project from the surface of the specimens, or may be disclosed by treating the surface with a weak acid. The figures here given may suffice to show some of these conditions of 
mineralization in ordinary limestones, and the effects which they produce (Fig. 23).

The mineral matters which thus aid in preserving fossils are of various kinds, and the whole subject is a very curious one; but for the present we may content ourselves with two kinds of mineralization - that by silicates and that by magnesian limestone or dolomite.

From the bottom of modern seas the dredge often brings up multitudes of minute shells, especially those of the simple gelatinous Protozoa, known as Foraminifera, whose internal cavities and pores have been filled with a greenish mineral composed of silica, iron and potash, combined with water (or, chemically speaking, a hydrous silicate of iron and potassium), which is named glauconite from its bluish-green colour - a name which we shall do well to remember. In such compounds, bases of similar chemical properties often replace one another, so that various glauconites differ somewhat in composition, the iron being in part often replaced by alumina or magnesia, and the potash by soda. The combined water also differs somewhat in its percentage. When minute shells fossilized in this way are treated with an acid so as to remove the calcareous shell itself, the enclosed silicate remains as a beautiful cast or core, 
representing all the forms of the interior, and any pores that may have penetrated the walls, and also perfectly representing the soft gelatinous body of the animal which once tenanted the shells (Fig. 24). (See also Fig. 25 at end of chapter.)

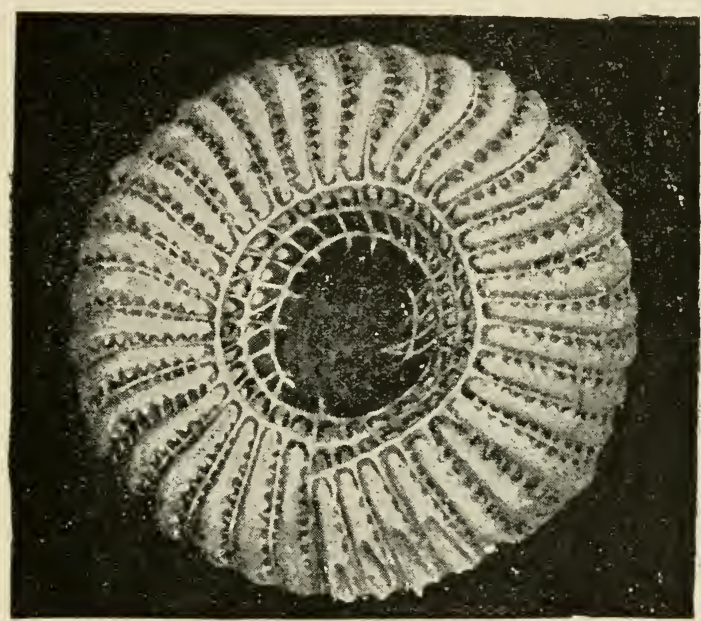

FIG. 24.-C'ast of Cavities of Yolystomella in Giunconile (magnified). After a photograph from Dr. Carpenter, and mounted specimens from his collection.

When we examine oceanic sediments of older date, we find similar fillings in limestones, chalks, and sandstones of various ages, some of the latter containing glauconite so abundantly as to bear the name of greensands, from their colour; and in these older examples we more frequently find alu- 
mina and magnesia occupying a large place in the mineralizing silicate. Fig. $24 \mathrm{~A}$ gives two illustrations of this-one a crinoidal stem from the Silurian of New Brunswick, injected with a silicate of alumina,
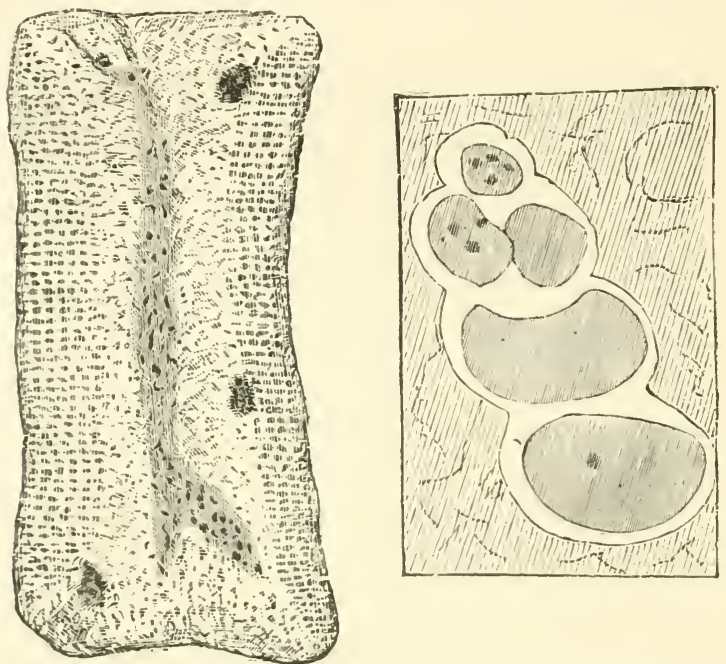

FIG. 24A.-(a) Joint of Crinoid injected with a Hydrous Silicate, Silurian, Pole Hill, New Brunswick. ( $\times$ 25.)

(b) Spiral Shell injected with a Hydrous Silicate allied to Serpentine, near Llangwyllog, North Wales. ( $\times$ 25.)

iron, magnesia and potash; the other a spiral shell from more ancient perhaps Cambrian rocks in Wales, filled with a silicate apparently more nearly related to serpentine. Further examples will be referred to in an appended note. 
We may now consider shortly the relation of dolomite, or the mixed carbonates of lime and magnesia, to the preservation of fossils. The presence of dolomite or magnesian limestone in these beds does not affect the conclusion as to their probable organic origin. This form of limestone occurs abundantly in later formations, and is even forming in connection with coral deposits in the modern ocean.

Dana has shown this by his observations on the occurrence of dolomite in the elevated coral island of Matea in Polynesia, ${ }^{1}$ under circumstances which show that it was formed in the lagoon of an ancient coral atoll, or ring-shaped island, while he finds that coral and coral sands of the same elevated reef contain very little magnesia. He concludes that the introduction of magnesia into the consolidating under-water coral sand or mud has apparently taken place-“"(I) In sea-water at the ordinary temperature; and (2) without the agency of any other mineral water except that of the ocean"; but the sand and mud were those of a lagoon in which the saline matter was in process of concentration by evaporation under the solar heat. Klement has

1 "Corals and Coral Islands," p. 356, etc. 
more recently taken up this fact in the way of experiment, and finds that, while in the case of ordinary calcite this action is slow and imperfect, with the aragonite which constitutes the calcareous framework of certain corals, ${ }^{1}$ and at temperatures of $60^{\circ}$ or over, it is very rapid and complete, producing a mixture of calcium and magnesium carbonates, from which a pure dolomite more or less mixed with calcite may subsequently result. ${ }^{2}$

I regard these observations as of the utmost importance in reference to the relations of dolomite with fossiliferous limestones, and especially with those of the Grenville series. The waters of the Laurentian ocean must have been much richer in salts of magnesium than those of the present seas, and the temperature was probably higher, so that chemical changes now proceeding in limited lagoons might have occurred over much larger areas. If at that

1 Aragonite, like ordinary limestone, is calcium carbonate, but its atoms seem to be differently arranged, so as to make it a less stable compound, and it has a different crystalline form. Some calcareous organisms are composed of aragonite, others of ordinary calcite.

2 "Bulletin Geol. Soc. Belgium," vol. ix. (1895, p. 3). Also notice in Geol. Mag., July, I895, p. 329. 
time there were, as in later periods, calcareous organisms composed of aragonite, these may have been destroyed by conversion into dolomite, while others more resisting were preserved, just as a modern Polytrema or Balanus might remain, when a coral to which it might be attached would be dolomitized, or might even be removed altogether by sea-water containing carbonic acid. There is reason to believe that this last change sometimes takes place in the deeper parts of the ocean at present. This would account for the persistence of Eozoon and its fragments, when other organisms may have perished, and also for the frequent filling of the canals and tubuli with the magnesian carbonate.

The main point here, however, for our present purpose is that, when a calcareous shell or skeleton has been thus infiltrated with a silicate, it becomes imperishable, so that any amount of alteration of the containing limestone short of its absolute fusion would not suffice to destroy an organism once injected with silicious matter. Thus the occasional persistence of silicified fossils in highly metamorphosed limestones is in no respect contradictory to the general fact, that when not preserved by sili- 
cious infiltration, they have perished, and this more especially in the case of those whose skeletons are composed of aragonite.

Carrying these facts with us, the next question is, What manner of fossil remains should we expect to find in the Upper Laurentian rocks, supposing that any such are therein preserved? The answer to this question follows at once from the facts as to the succession of life noticed above. Only the marine invertebrates have been traced as far back as the oldest Cambrian, and only Worms, Sponges, and Protozoa into the Huronian. We should therefore have no expectation of finding remains of any vertebrate animals or of any of the land invertebrates; and even allowing for the more favourable conditions, as compared with the Huronian, evidenced by the great limestones and the abundant carbon, we could scarcely expect anything higher than some of the lower types of invertebrate life, such as Worms, Hydroids, Corals and Protozoa. We have next to inquire what forms, possibly organic, have actually been found, and what information we can derive from them as to the beginnings of life. Since, however, such discoveries as have been made have been the result of much labour and scientific skill brought 
to bear on these old rocks, and are connected with the reputations of several eminent men, now deceased, we may first refer shortly to the history of the discovery of supposed fossils in the Laurentian rocks of Canada.

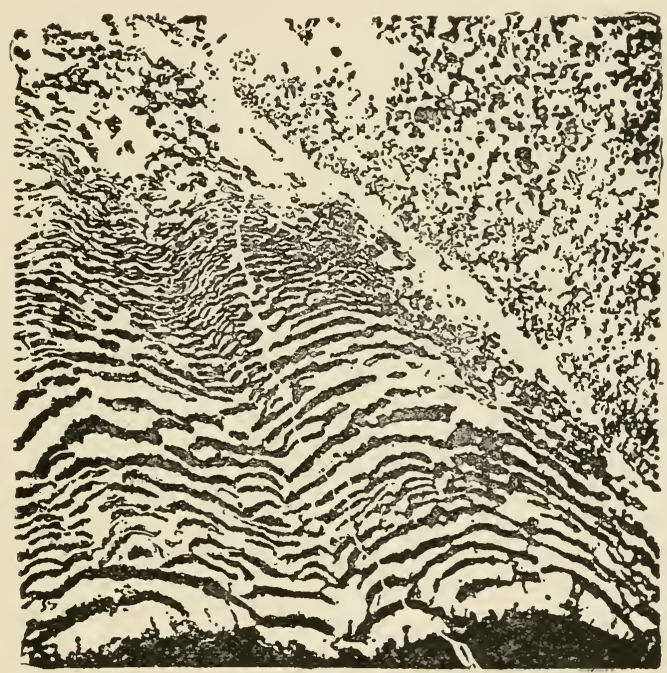

FIG. 25.-Nature-print of an eiched Spccimen of Eozoon.

Showing the laminæ, a part of the natural margin, near which passes a diagonal calcite vein, and at the upper right-hand corner, fragmental material with casts of Archæospherinæ. The dark lines represent the chambers filled with serpentine, the white the calcite wall. 

THE HISTORY OF A DISCOVERY 



\section{VI}

THE HISTORY OF A DISCOVERY

W ${ }^{\mathrm{HEN}}$ Mr. Logan, afterwards Sir William Logan, entered on the Geological Survey of Canada, in I840, he found that vast and littleexplored regions in the northern part of that country were occupied with gneissic rocks, similar to the oldest gneisses of Scotland and Scandinavia, and to which the name Azoic had been given by Murchison, as rocks destitute of fossils, while they had been the "fundamental granite" or ur-gneiss of most European geologists. They were unquestionably below and more ancient than the oldest fossiliferous Cambrian rocks both in Europe and North America, and geologists had for the most part contented themselves with regarding them as primitive rocks, destitute of any geological interest, much as some United States geologists of the present day call them the "Archæan complex," a name which the late Prof. Dana has well characterized as a "term of despair." 
Logan was, however, a man not to be daunted by an unsolved problem, even though the facts for its solution must be sought in a wilderness known to few except adventurous trappers, hunters, and lumbermen; and he soon learned that this ancient gneissic formation contained other rocks beside gneiss, more especially thick and extensive limestones, and that its beds seemed to have a definite arrangement, and could be traced over great areas. $\mathrm{He}$ addressed himself, therefore, to the problem of unravelling the tangled "complex," and with a few hardy assistants, spent years in laboriously tracing its beds along river courses and over mountains, and in mapping, in a manner never previously attempted, its several members, designating at the same time the whole by the term "Laurentian," because it constituted the mass of the hills lying north of the St. Lawrence, called by old French geographers the Laurentides, and separating the St. Lawrence Valley and the region of the great lakes from Hudson's Bay and the Arctic Sea. In this manner he laid a foundation, which still remains unshaken, for the geology of the oldest rocks, and prepared the way for the discovery of the forms afterward named Eozoon Canadense. At the same time Dr. Sterry Hunt, the chemist of 
the Survey, was examining chemically the rocks and minerals collected, and all Sir William's assistants were instructed to search, more especially in the limestones, for anything bearing the aspect of fossils. On the other hand, Dr. Carpenter was independently pursuing his studies of the humbler inhabitants of the modern ocean, and of the manner in which the pores of their skeletons became infiltrated with mineral matter, and had kindly contributed specimens to the collections of the writer in Canada. The discovery of this most ancient fossil was thus not the chance picking up of a rare and curious specimen, but the result of several combined lines of laborious and skilful research.

The following notice of the persons and incidents connected with its discovery is taken from a previous publication of the writer, with only a little alteration in terms to suit it to the present date.

The first specimens of Eozoon ever procured, in so far as known, were collected at Burgess, in Ontario, by a veteran Canadian mineralogist, Dr. Wilson of Perth, and were sent to Sir William Logan as mineral specimens. Their chief interest at that time lay in the fact that certain laminæ of a dark green mineral present in the specimens 
were found, on analysis by Dr. Hunt, to be composed of a new hydrous silicate, allied to serpentine, and which he named loganite, but which seems to be a mixture of different silicates. The form of this mineral was not suspected to be of organic origin. Some years after, in 1858 , other specimens, differently mineralized with the minerals serpentine and pyroxene, were found by Mr. J. McMullen, an explorer in the service of the Geological Survey, in the limestone of the Grand Calumet on the river Ottawa. These seem to have at once struck Sir IV. E. Logan as resembling the Silurian fossils known as Stromatopore, or layer-corals, and at that time of quite uncertain nature, though supposed to be allied to some kinds of modern corals. $\mathrm{He}$ showed them to Mr. Billings, the palæontologist of the Survey, and to the writer, with this suggestion, confirming it with the sagacious consideration that inasmuch as the Ottawa and Burgess specimens were mineralized by different substances, yet were alike in form, there was little probability that they were merely mineral or concretionary. Mr. Billings was naturally unwilling to risk his reputation in affirming the organic nature of such specimens; and my own suggestion was that they should be 
sliced, and examined microscopically; and that if fossils, as they presented merely concentric laminæ and no cells, they would probably prove to be protozoa rather than corals. A few slices were accordingly made, but no definite structure could be detected. Nevertheless, Sir William Logan took some of the specimens to the meeting of the American Association at Springfield, in 1859, and exhibited them as possibly Laurentian fossils; but the announcement was evidently received with some incredulity. In I862 they were exhibited by Sir William to some geological friends in London, but he remarks that "few seemed disposed to believe in their organic character, with the exception of my friend Professor Ramsay." In 1863 the General Report of the Geological Survey, summing up its work to that time, was published, under the name of the "Geology of Canada," and in this, at page 49, will be found two figures of one of the Calumet specimens, here reproduced, and which, though unaccompanied with any specific name or technical description, were referred to as probably Laurentian fossils (Figs. 26 and 27).

About this time Dr. Hunt happened to mention to $\mathrm{me}$, in connection with a paper on the mineralization 


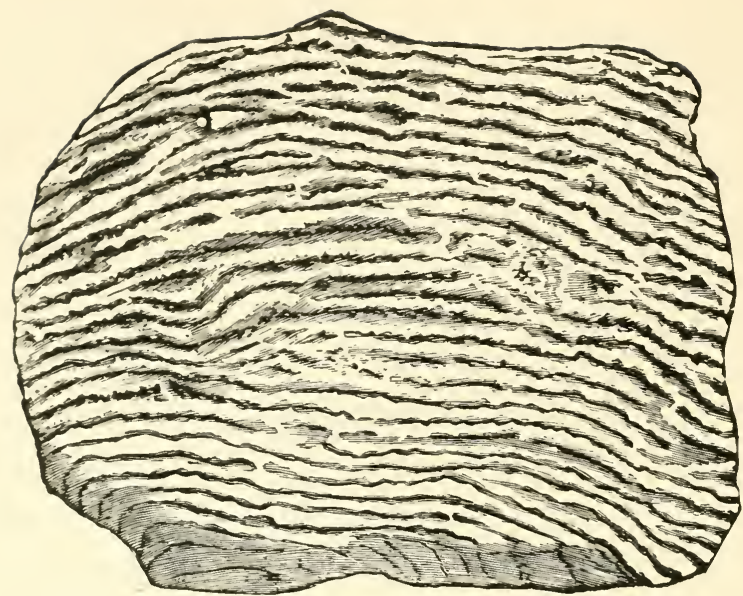

FIG. 26. - Weathered Specimen of Eozoon from the Grand Calumet. (Collected by Mr. McMullen.)

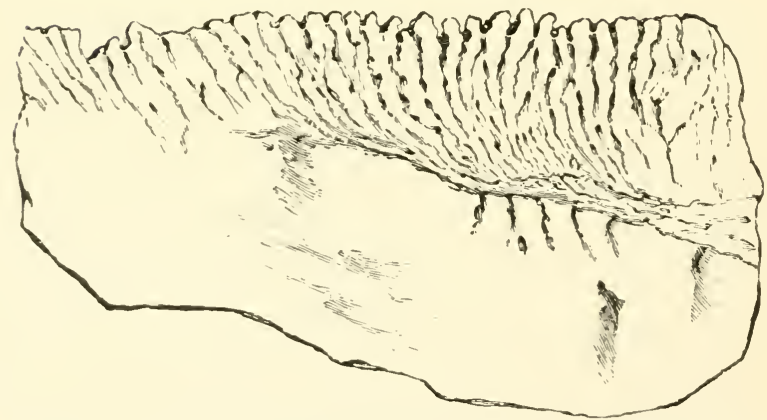

FIG. 27.-Cross Section of the Specimen represented in Fig. 26.

The dark parts are the laminæ of calcareous matter converging to the outer surface. 
of fossils which he was preparing, that he proposed to notice the mode of preservation of certain fossil woods and other things with which I was familiar, and that he would show me the paper in proof, in order that he might have any suggestions that occurred to me. On reading it, I observed, among other things, that he alluded to the supposed Laurentian fossils, under the impression that the organic part was represented by the serpentine or loganite, and that the calcareous matter was the filling of the chambers. I took exception to this, stating that though in the slices before examined no structure was apparent, still my impression was that the calcareous matter was the fossil, and the serpentine or loganite the filling. He said: "In that case, would it not be well to re-examine the specimens, and to try to discover which view is correct?" He mentioned at the same time that Sir William had recently shown him some new and beautiful specimens collected by Mr. Lowe, one of the explorers on the staff of the Survey, from a third locality, at Grenville, on the Ottawa. It was supposed that these might throw further light on the subject; and accordingly Dr. Hunt suggested to Sir William to have additional slices of these new specimens made by Mr. Weston, 
of the Survey, whose skill as a preparer of these and other fossils has often done good service to science. A few days thereafter, some slices were sent to me, and were at once put under the microscope. I was delighted to find in one of the first specimens examined, which happened to be cut parallel to the laminæ, a beautiful group of tubuli penetrating one of the calcite layers. Here was evidence, not only that the calcite layers represented the true skeleton of the fossil, but also of its affinities with the Foraminifera, whose tubulated supplemental skeleton, as described and figured by Dr. Carpenter, and represented in specimens in my collection presented by him, was evidently of the same type with that preserved in the canals of these ancient fossils. Fig. 28 is an accurate representation of the first seen group of canals penetrated by serpentine.

On showing the structures discovered to Sir IVilliam Logan, he entered into the matter with enthusiasm, and had a great number of slices and afterwards of decalcified specimens prepared, which were placed in my hands for examination.

Feeling that the discovery was most important, but that it would be met with determined scepticism on the part both of geologists and biologists, 
I was not content with examining the typical specimens of Eozoon, but had slices prepared of

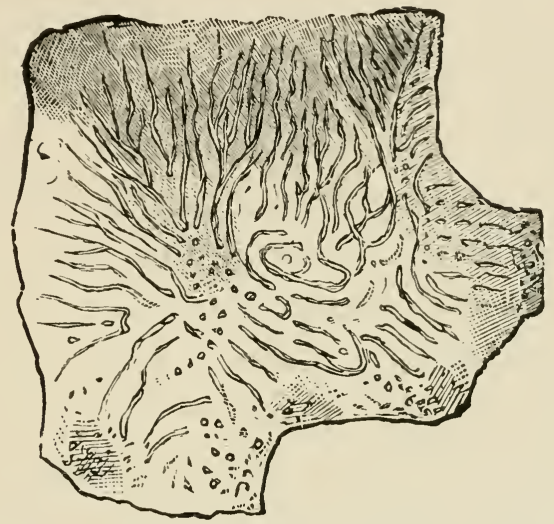

FIG. 28.-Group of Canals in the Supplemental Skeleton of Eozoon. Taken from the specimen in which they were first recognised. (Magnified.)

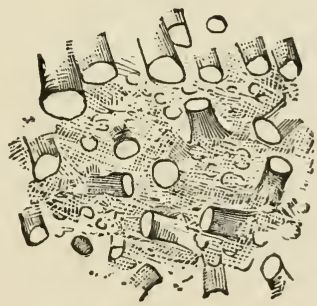

Fig. 29.-Canals of Eozoon, from same specimen. (Highly magnified.)

every variety of Laurentian limestone, of altered limestones from the Cambrian and Silurian, and of 
serpentine marbles of all the varieties furnished by our collections. These were examined with ordinary and polarized light, and with every variety of illumination. Dr. Hunt, on his part, undertook the chemical investigation of the various associated minerals. An extensive series of notes and camera tracings were made of all the appearances observed; and of some of the more important structures beautiful drawings were executed by the late Mr. H. S. Smith, the then palæontological draughtsman of the Survey. The result of the whole investigation was a firm conviction that the structure was organic and probably foraminiferal, and that it could be distinguished from any merely mineral or crystalline forms occurring in these or other limestones.

At this stage of the matter, and after exhibiting to Sir William all the characteristic appearances in comparison with such concretionary, dendritic, and crystalline structures as most resembled them, and also with the structure of recent and fossil Foraminifera, I suggested that the further prosecution of the matter should be handed over to Mr. Billings, as palæontologist of the Survey, and as our highest authority on the fossils of the older rocks. I was engaged in other researches, and 


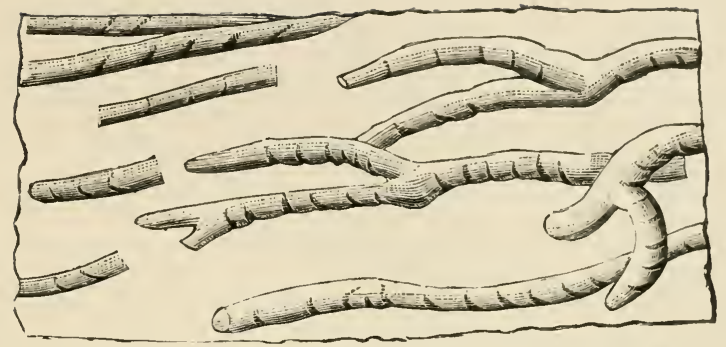

FIG. 30.-Casts of Canals of Eozoon, in Serpenitine. Decalcified and highly magnified.

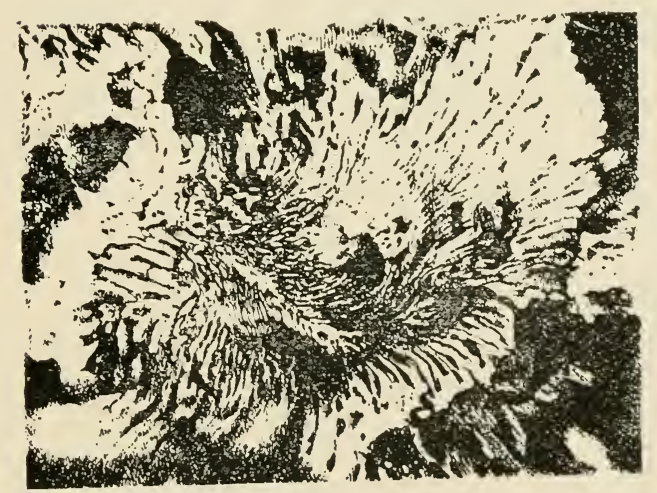

FIG. 31.-Group of finest Tubuli.

Highly magnified, from a micro-photograph. 

knew that no little labour must be devoted to the work and to its publication, and that some controversy might be expected. Mr. Billings, however, with his characteristic caution and modesty, declined. His hands, he said, were full of other work, and he had not specially studied the microscopic appearances of Foraminifera or of mineral substances. It was finally arranged that I should prepare a description of the fossil, which Sir William would take to London, along with Dr. Hunt's notes, the more important specimens, and lists of the structures observed in each. Sir William was to submit the manuscript and specimens to Dr. Carpenter, and also to Prof. T. Rupert Jones, in the hope that these eminent authorities would confirm our conclusions, and bring forward new facts which I might have overlooked or been ignorant of. Sir William saw both gentlemen, who gave their testimony in favour of the organic and foraminiferal character of the specimens; and Dr. Carpenter in particular gave much attention to the subject, and worked out the structure of the delicate tubulation of the surfaces of the laminæ or cell-walls, which I had not distinguished previously, through a curious accident as to specimens. Mr. Lowe 
had been sent back to the Ottawa to explore, and just before Sir William's departure had sent in some specimens from a new locality at Petite Nation, similar in general appearance to those from Grenville, which Sir William took with him unsliced to England. These showed in a perfect manner the tubuli of the primary cell-wall, which I had in vain tried to resolve in the Grenville specimens, and which I did not see until after they had been detected by Dr. Carpenter in London. Dr. Carpenter thus contributed in a very important manner to the perfecting of the investigations begun in Canada, and on him fell the greater part of their illustration and defence, ${ }^{1}$ in so far as Great Britain is concerned.

The immediate result was a composite paper in the Proceedings of the Geological Society, by Sir W. E. Logan, Dr. Carpenter, Dr. Hunt, and myself, in which the geology, palæontology, and mineralogy of Eozoon Canadense and its containing rocks were first given to the world. ${ }^{2}$ It cannot be wondered

1 In papers by Dr. Carpenter, subsequently referred to, Prof. Jones published an able exposition of the facts in the Popular Science Monthly.

${ }^{2}$ In Quarterly Journal of Geological Society, vol. xxii.; Proc. 
at that when geologists and palæontologists were thus required to believe in the existence of organic remains in rocks regarded as altogether Azoic and hopelessly barren of fossils, and to carry back the clawn of life as far before those Cambrian rocks, which were supposed to contain its first traces, as these are before the middle period of the earth's life-history, some hesitation should be felt. Further, the accurate appreciation of the evidence for such a fossil as Eozoon required an amount of knowledge of minerals, of the more humble types of animals, and of the conditions of mineralization of organic remains, possessed by few even of professional geologists. Thus Eozoon has met with some negative scepticism and positive opposition -though the latter has been smaller in amount than might have been anticipated, when we consider the novel and startling character of the facts adduced. The most annoying element in the discussion has consisted in the liability of observers, only partially informed, to confound our specimens

Royal Society, vol. xv. ; Intellectual Observer, 1865; Annals and Magazine of Natural History, 1874; and other papers and notices.

1 Journal Geological Society, February, 1865. 
with things of very different character, from which we had taken pains to distinguish them.

"The united thickness," says Sir William Logan, "of these three great series, the Lower and Upper Laurentian and Huronian, may possibly far surpass nat of all succeeding rocks, from the base of the Palæozoic to the present time. We are thus carried back to a period so far remote that the appearance of the so-called Primordial fauna may be considered a comparatively modern event." So great a revolution of thought, and this based on one fossil, of a character little recognisable by geologists generally, might well tax the faith of a class of men usually regarded as somewhat faithless and sceptical. Yet this new extension of life has been very generally received, and has found its way into text-books and popular treatises. Its opponents have been under the necessity of inventing the most strange and incredible pseudomorphoses of mineral substances to account for the facts. As might have been expected, after the publication of the original paper, other facts developed themselves. Mr. Vennor found other and scarcely altered specimens closely allied to the Laurentian forms in the Hastings series of Tudor, probably of Huronian age. Gümbel re- 
cognised the organism in Laurentian rocks in Bavaria and elsewhere in Europe, and discovered a new species in the Huronian of Bavaria.' Eozoon was recognised in Laurentian limestones in Massachusetts $^{2}$ and New York, and there has been a rapid growth of new facts increasing our knowledge of Foraminifera and other humble animals in the succeeding Eozoic and Palæozoic rocks. Special interest attaches to the discovery by Mr. Vennor, and by Walcott and Matthew, to be mentioned in the sequel, and tending to bridge over the interval between the Laurentian fossil and those of the Lower Cambrian. Another fact, whose significance is not to be over-estimated, is the recognition both by Dr. Carpenter and myself of specimens in which the canals are occupied by dolomite or by calcite like that of the organism itself. I have made several visits to the locality at Petite Nation originally discovered by Mr. Lowe, in

1 Ueber das Vorkommen von Eozoon, 1866.

${ }^{2}$ By Mr. Bicknell at Newbury, and Mr. Burbank at Chelmsford. The latter gentleman has since maintained that the limestones at the latter place are not true beds; but his own descriptions and figures lead to the belief that this is an error of observation on his part. The Eozoon in the Chelmsford specimens and in those of Warren, New York, is in small and rare fragments in serpentinous limestone. 
company with Dr. Carpenter, Dr. Bonney, ${ }^{1}$ and other skilled observers, and have very carefully studied all the facts with reference to the mode of occurrence of the forms in the beds, and their association with layers of fragmental Eozoon, and have found that these are strictly in accordance with the theory that these old Laurentian limestones are truly marine deposits, holding the remains of the sea animals of their time.

Eozoon is not, however, the only witness to the great fact of Laurentian life, of which it is the most conspicuous exponent. In many of the Laurentian limestones, mixed with innumerable fragments of Eozoon, there are other fragments with traces of organic structure of a different character. There are also casts in silicious matter which seem to indicate smaller species of Foraminifera; and large laminated forms, apparently organic, yet distinct from Eozoon. Some of these must be noticed in the following pages.

Other discoveries also are foreshadowed here. The microscope may yet detect the true nature and

${ }^{1}$ See an excellent account of one of these visits by Dr. Bonney, Geological Magazine, I 895. 
affinities of some of the fragments associated with Eozoon. Less altered portions of the Laurentian rocks may be found, where even the vegetable matter may retain its organic forms, and where fossils may be recognised by their external outlines as well as by their internal structure. Thus the time may come when the rocks now called Primordial shall not be held to be so in any strict sense, and when swarming dynasties of Protozoa and other low forms of life may be known as inhabitants of oceans vastly ancient as compared with even the old Primordial seas. Who knows whether even the land of the Laurentian time may not have been clothed with plants, perhaps as much more strange and weird than those of the Devonian and Carboniferous, as those of the latter are when compared with modern forests ? 

THE DAWN OF LIFE

145

IO 



\section{VII}

\section{THE DAWN OF LIFE}

$\mathrm{N}$ the Grenvillian system, as represented in the vicinity of the Ottawa River, perfect specimens of Eozoon are found in one only of the principal limestones there exposed, and in certain layers of that limestone, and they are associated with concretions and grains of the greenish mineral serpentine, which, as we shall see, has much to do with their preservation. As exposed on broken surfaces, the specimens consist of concentric layers of greenish serpentine and white calcite, not, however, even or uniform, as in ordinary concretions having concentric structure, but often àpproaching and uniting with each other, so as to constitute wide flat chambers, and forming patches from an inch to nearly a foot in diameter, while some of the larger patches seem to coalesce or to become confluent. On weathered surfaces the serpentine laminæ often become brown, owing to the rusting of the iron contained in them, and project above the general 
surface, in this case resembling very much the appearance of the layer-corals so plentiful in some limestones of later date.

The external forms of Eozoon are at first sight not very obvious, as they adhere very closely to the containing rock; but the smaller specimens, when entirely weathered out or disengaged by the solution of the limestone in an acid, usually present the form of a broad inverted cone, like some modern sponges or the broader turbinate fossil corals (Fig. 32). The limestone having, like the other beds of the formation, been much compressed and folded, the specimens of Eozoon are sometimes crumpled in these folds or broken across by small cracks or faults, which shift the laminæ slightly out of their places. The cracks thus formed are also sometimes filled with a fibrous variety of serpentine, known to mineralogists as chrysotile and popularly as "rock cotton" or "asbestus." It is finely fibrous, and of a silky lustre, and must have been deposited by water in the cracks and fissures formed by the fracturing of the rock and the contained fossils, by movements taking place after the whole was hardened. Accordingly these veins often cross not only the rock, but also the serpentine and calcite layers of the contained 


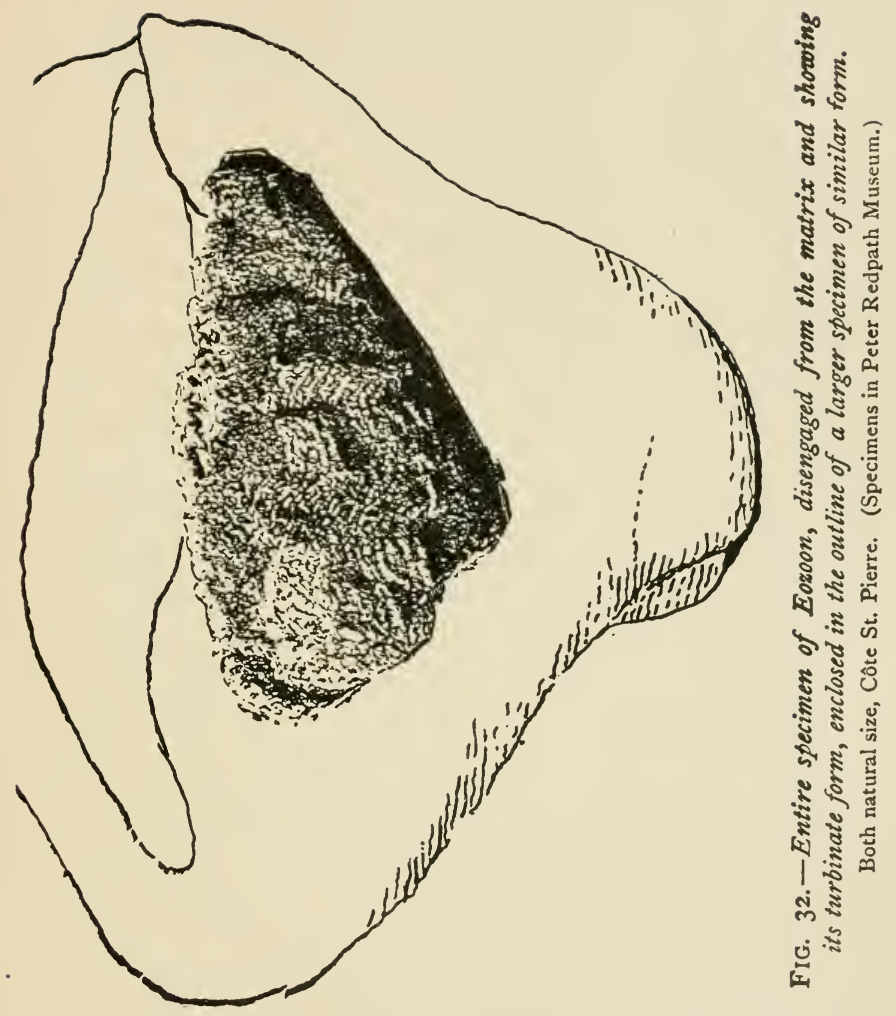



masses of Eozoon, without regard to the direction of their laminæ, though sometimes they run parallel to the structure, the rock having broken more easily in that direction.

Bearing in mind these general points of material form and appearance, we may now proceed to inquire as to the following points: (I) The structures visible in the specimens; (2) The manner in which they are represented by different mineral substances, and how these are to be accounted for; (3) The explanation of the whole on the supposition that we are dealing with an animal fossil.

(I) In regard to the first of these questions, I may quote here, with some slight alteration, from a recent memoir of my own : ${ }^{1}$ -

In recent years I have been disposed to attach more importance than formerly to the general form of Eozoon. The earlier examples studied were, for the most part, imbedded in the limestone in such a manner as to give little definite information as to external form ; and at a later date, when Sir William Logan employed one of his assistants, Mr. Lowe, to quarry large specimens at Grenville and Côte St.

1 London Geological Magazine, 1895. 
Pierre, the attempt was made to secure the most massive blocks possible, in order to provide large slabs for showy museum specimens. More recently, when collections have been made from the eroded and crumbling surfaces of the limestone in its wider

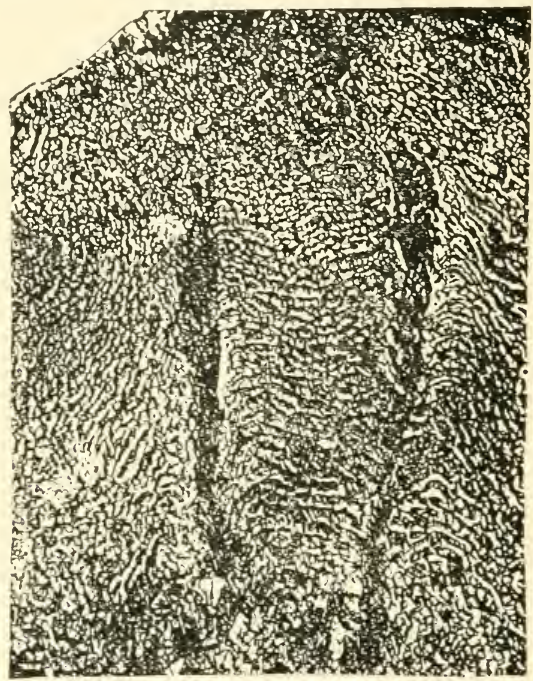

Fig. 33. - Weathered surface of Eozoon.

Showing sections of two funnels or tubes with limiting walls, Côte St. Pierre.

exposures, it was found that specimens of moderate size had been weathered out, and could, either naturally or by treatment with acid, be entirely separated from the matrix. Such specimens sometimes showed, either on the surfaces or on the sides 
of "funnels" and tubes penetrating the mass (Figs. 33, 34), a confluence of the laminæ, constituting a porous cortex or limiting structure. Specimens of this kind were figured in I888, and I was enabled to add to the

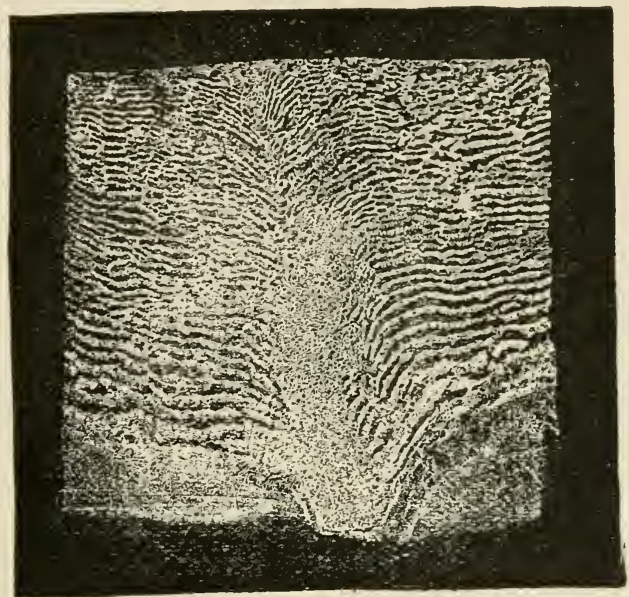

Fig. 34.--Section of the Base of a specimen of Eozoun.

This specimen shows an osculiform, cylindrical funnel, cut in such a manner as to show its reticulated wall and the descent of the laminæ toward it. Two-thirds of natural size. From a photograph. Col. Carpenter, also in Redpath M useum.

[This illustration (from Prof. Prestwich's "Geology," vol. ii. p. 2r) has been courteously lent by the Clarendon Press, Oxford.]

characters of the species that the original and proper form was "broadly turbinate with a depression or cavity above, and occasionally with oscula or pits penetrating the mass." The great flattened masses thus seemed to represent confluent or overgrown 
individuals, often contorted by the folding of the enclosing beds.

There are also in well-preserved specimens certain constant properties of the calcite and serpentine layers. The former are continuous, and connected at intervals, so that if the silicious filling of the chambers could be removed, the calcareous portion would form a continuous skeleton, while the serpentine filling the chambers, when the calcareous plates are dissolved out by an acid, forms a continuous cast of the animal matter filling the chambers (Fig. 36). This cast of the sarcodous material, when thus separated, is very uniformly and beautifully mammillated on the surfaces of the laminæ, and this tuberculation gradually passes upward into smaller chambers having amoeboid outlines, and finally into rounded chamberlets. It is also a very constant point of structure that the lower laminæ of calcite are thicker than those above, and have the canal-systems larger and coarser. There is thus in the more perfect specimens a definite plan of macroscopical structure (Fig. 35).

The normal mode of mineralization at Côte St. Pierre and Grenville is that the laminæe of the test remain as calcite, while the chambers and 


\section{${ }^{2} 0^{2}-8$}

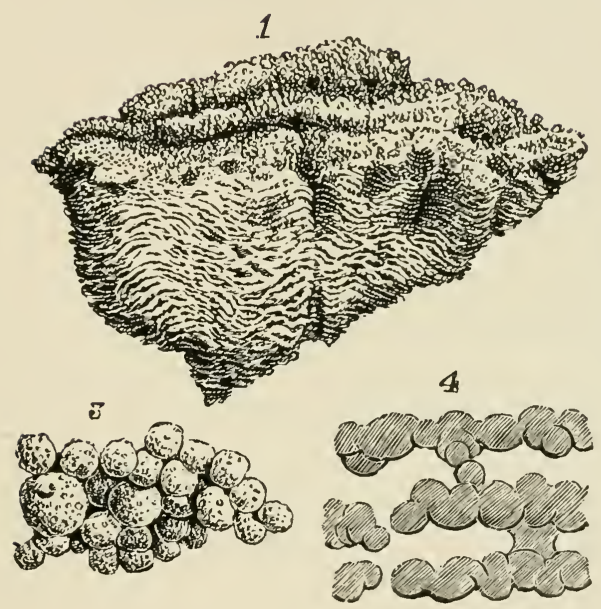

FIG. 35.-Structure of small specimen of Eozoon, calcareous matter removed.

I. Natural size. 2. Acervuline cells of upper part. 3. Group of the same coalescing into a lamina with tuberculated surface. 4. Laminæ with tuberculated surfaces in section. (See also Fig. 36.) 

larger canals are filled with serpentine of a light green or olive colour, and the finer tubuli are injected with dolomite. It may also be observed

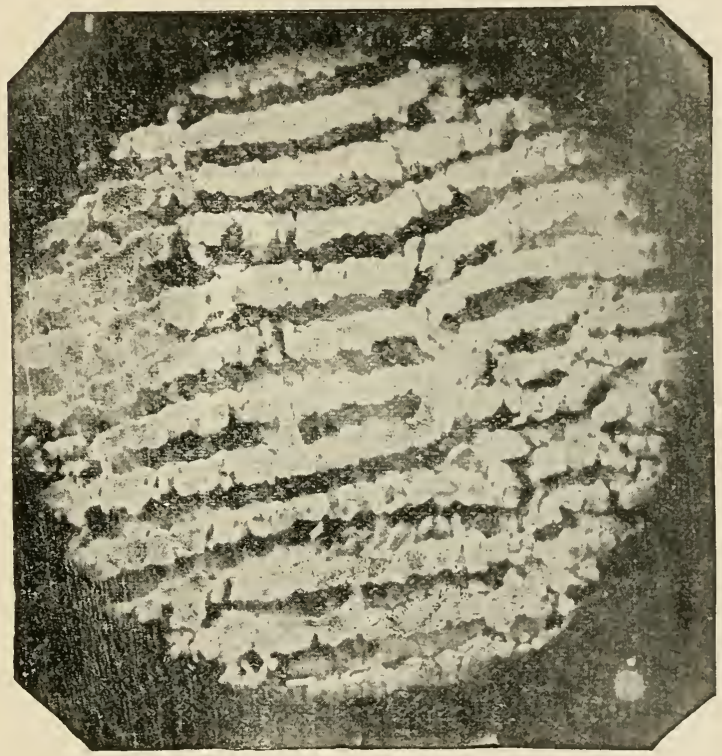

FIG. 36.-Decalcified Eozoon, in section, slightly enlarged. Showing the character of the sarcodous laminæ now replaced by Serpentine.

that the serpentine in the larger cavities often shows a banded structure, as if it had been deposited in successive coats, and the canals are sometimes lined with a tubular film of serpentine, 
with a core or axis of dolomite, which also extends into the finer tubuli of the surfaces of the laminx. This, on the theory of animal origin, is the most perfect state of preservation, and it equals anything I have seen in calcareous organisms of later periods. This state of perfection is, however, naturally of infrequent occurrence. The finer tubuli

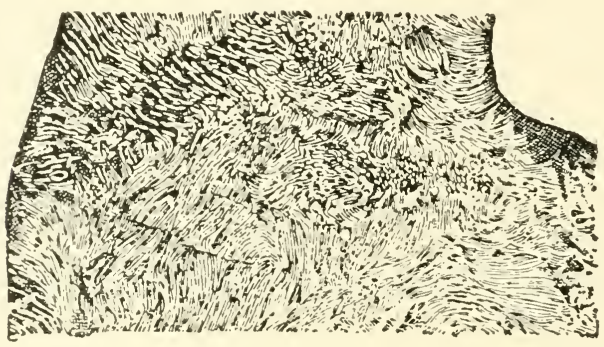

FIG. 37.-Finest Tubuli filled with Dolomite (magnified).

are rarely perfect or fully infiltrated. Even the coarser canals are not infrequently imperfect, while the lamina themselves are sometimes crumpled, crushed, faulted, or penetrated with veins of chrysotile or of calcite. In some instances the calcareous lamine are replaced by dolomite, in which case the canal-systems are always imperfect or obsolete. The laminae of the test itself are also in 
some cases replaced by serpentine in a flocculent form. At the opposite extreme are specimens, or portions of specimens, in which the chambers are obliterated by pressure, or occupied only with calcite. In such cases the general structure is entirely lost to view, and scarcely appears in weathering. It can be detected only by micro-

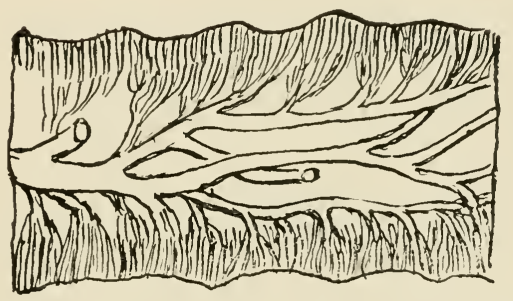

FIG. 38. - Plan of arrangement of Canals in Lamina of Eozoon.

scopic examination of slices, in parts where the granular structure or the tubulation of the calcite layers has been preserved. All palæontologists who have studied silicified fossils in the older rocks are familiar with such appearances.

It has been alleged by Möbius and others that the canal-systems and tubes present no organic regularity. This difficulty, however, arises solely from imperfect specimens or inattention to the necessary results of slicing any system of ramify- 
ing canals. In Eozoon the canals form ramifying groups in the middle planes of the laminæ, and proceed at first almost horizontally, dividing into smaller branches, which ultimately give off brushes of minute tubuli running nearly at right angles to the surfaces of the lamina, and forming the extremely fine tubulation which Dr. Carpenter regarded as

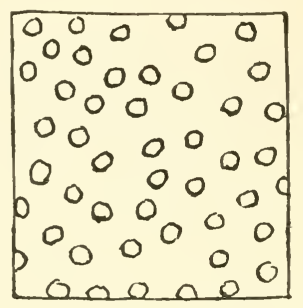

FIG. 39.-Cross section of minute l'ubuli, about 5 microns. in diameter (magnified).

the proper wall (Figs. 38, 39). In my earlier description I did not distinguish this from the canalsystem, with which its tubuli are inwardly continuous. Dr. Carpenter, however, understood this arrangement, and has represented it in his figures ${ }^{1}$ (see also Fig. 28). It is evident that in a structure like this a transverse or oblique section will show truncated portions of the larger tubes appar-

1 "Ann. and Mag. Nat. Hist.," ser. 4, xiii., p. 456, figs. 3, 4. 
ently intermixed with others much finer and not continuous with them, except very rarely. Good specimens and many slices and decalcified portions are necessary to understand the arrangement This consideration alone, I think, entirely invalidates the criticisms of Möbius, and renders his large and costly figures of little value, though his memoir is, as I have elsewhere shown, liable to other and fatal objections. ${ }^{1}$

It has been pretended that the veins of chrysotile, when parallel to the laminæ, cannot be distinguished from the minute tubuli terminating on the surfaces of the laminæ. I feel confident, however, that no microscopist who has seen both, under proper conditions of preservation and study, could confound them. The fibres of chrysotile are closely appressed parallel prisms, with the optical properties of serpentine. The best preserved specimens of the "proper wall" contain no serpentine, but are composed of calcite with extremely minute parallel cylinders of dolomite about five to ten microms. in diameter, and separated by spaces greater than their own diameter (Figs. 4O, 4I). In

1. "Museum Memoir," pp. 50 et seq. 
the rare cases where the cylinders are filled with serpentine, they are, of course, still more distinct and beautiful. At the same time, I do not doubt that observers who have not seen the true tubu-

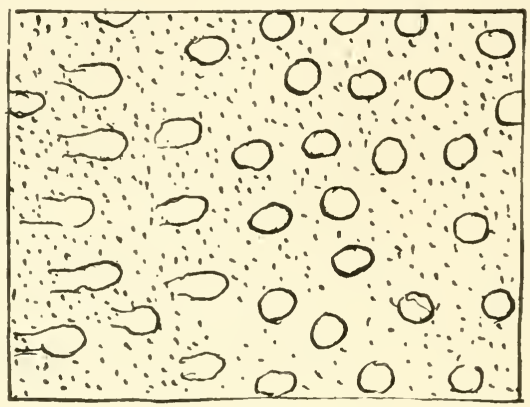

FIG. 40.-Cross section of similar Tubuli to those in Fig. 39, more highly magnified, and showing granular character of the test.

(From camera tracings.)
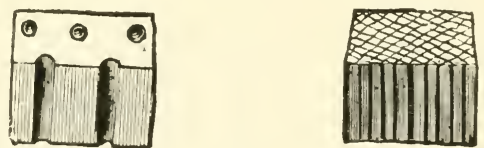

FIG. 41.-Comparison of Tubulate Wall and Prisms of Chrysotile in perspective.

lation may have been misled by chrysotile veins when these fringe the laminæ. Möbius, for instance, figures the true and false structure as if they were the same.

Protest should here be made against that mode 

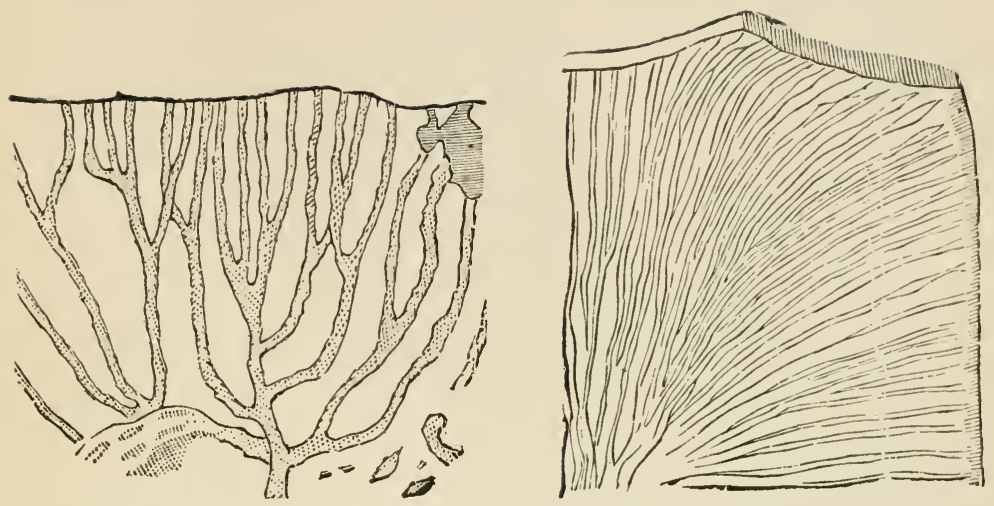

Canals of Eozoon. (After Möbius.) Finer Canals of Eozoon. (After Möbius.)

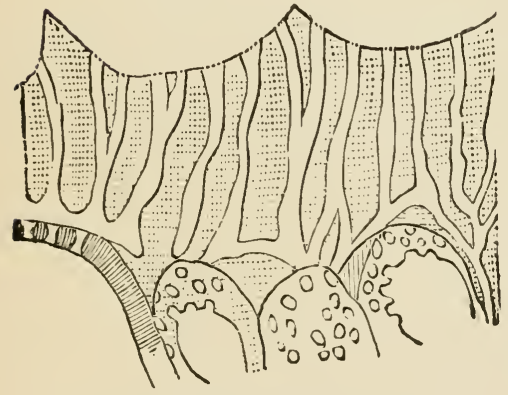

Canals of modern Calcarina. (After Carpenter.)

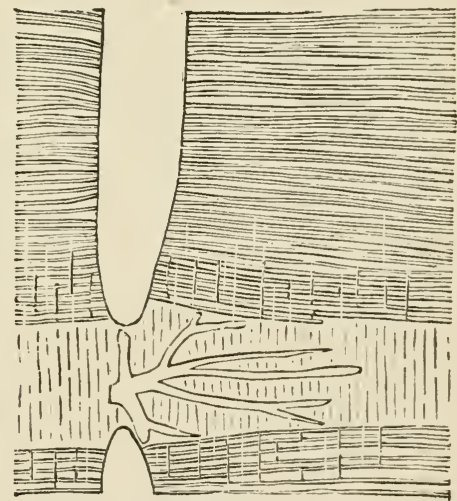

Canals and Tubule of Tertiary Nummulina. (After Möbius.)

FIG. 42.

Figures selected from Mrbius, to show the resemblance of structures of Eozoon to those of modern Foraminifera. 

of treating ancient fossils which regards the most obscure or defaced specimens as typical, and those better preserved as mere accidents, of mineral structure. In Tertiary Nummulites injected with glauconite it is rare to find the tubuli perfectly filled, except in tufts here and there; yet no one doubts that these patches represent a continuous structure.

I have remarked on previous occasions that the calcite constituting the laminæ of Eozoon often has a minutely granular appearance, different from that of the surrounding limestone. Under a high power it resolves itself into extremely minute dots or flocculi, somewhat uniformly diffused. Whether these dots are particles of carbon, iron, apatite, or silicious matter, or the remains of a porous structure, I do not know; but similar appearances occur in the calcareous fossils contained in altered limestones of later date. Wherever they occur in crystalline limestones, supposed to be organic, the microscopist should examine them with care. I have sometimes by this appearance detected fragments of Eozoon which afterward revealed their canals.

(2) The second question requires us to consider 
the nature and origin of the substances constituting the specimens. Reference has already been made to these in our fifth chapter, but they may be more particularly noticed here in connection with the forms as above described.

The calcareous laminæ are usually composed of clear translucent calcite or calcium carbonate, though, as in the case of many later fossils, sometimes replaced by dolomite. It often has the fine granular appearance above referred to, but is nearly always crystalline, and traversed by cleavage planes visible under the microscope. ${ }^{1}$ This crystalline structure, as every student of fossils knows, is very common in calcareous fossils of all geological ages. In the thicker laminæ the canals traversing them and branching out in their substance are usually visible under a low power, except when they are filled with calcite similar to that of the laminæ themselves. In this case they can be seen only by very careful management of an oblique and subdued light. When occupied with serpentine, this presents, in a thin slice under

${ }^{1}$ Especially when the specimen has been heated or jarred in the process of grinding or polishing. 
transmitted light, a yellowish or brownish colour, and in a specimen decalcified with an acid an opaque white appearance. In some of the larger threads of serpentine, as already stated, this mineral forms a thin outer cylinder with a core of calcite or dolomite within; but this appearance is not common. Here and there, especially in the lower layers, a portion of a tube is filled with the harder mineral pyroxene, which is in some respects similar to serpentine, except that it contains lime as well as magnesia, and is destitute of water as an ingredient. The finer tubuli into which the canals ramify are most usually filled with dolomite or magnesian limestone, which has a glossy appearance and higher lustre than the surrounding calcite, and so may be distinguished even in a transparent slice; but these fine dolomite threads are best seen when the surface of a slice is treated with a dilute acid in the cold, in which circumstances the calcite is dissolved, while the dolomite remains as tufts of delicate cylindrical hairs, presenting often a very beautiful appearance under the microscope. Thus, as in many other fossils, what are supposed to have been tubes and tubuli are found not empty, but filled with matter 
even harder and more resisting than the shell itself.

Serpentine is a mineral which has been produced in different ways. Some igneous or volcanic rocks consist largely of compounds of silica and magnesia (olivine, etc.). When these rocks have become cold and are exposed to the action of water, they sometimes absorb this and become hydrated, thus passing into a kind of serpentine. When such rocks are pulverized and dispersed as volcanic ash, this falling into the sea may be there hydrated, and may form serpentinous layers, or in a fine paste or in solution may pass into the pores and cavities of shells and other organic things, acting, as we have seen, in the same manner with ordinary glauconite. In like manner serpentine of this origin may form nodules or grains in limestones, in consequence of its particles being aggregated together by concretionary attraction. We have already seen that some comparatively modern socalled glauconites are essentially of the nature of serpentine, and we know that in the old Laurentian sea, salts of magnesia and magnesian minerals were abundant, so that serpentinous minerals might play a greater part than they do in the modern 
seas. Loganite, the mineralizing substance of the Burgess Eozoon, is different from serpentine, yet closely allied to the glauconites. The presence of pyroxene may be explained in a similar way. It is a frequent constituent of bedded volcanic rocks and of volcanic ashes, and beds of it occur in the Grenville series which once, no doubt, were ash-beds. Layers of it also occasionally occur from a similar cause in the limestone, and crystals of it have been deposited by water in the veins passing through the limestones and schists. Dr. Johnston-Lavis has described in the July number of the Geological Magazine for I895 the aqueous deposition at ordinary temperature of crystals of pyroxene and hornblende, in cavities and crevices of bones included in an ash-bed of recent date, and in presence of calcite, apatite, and fluoride of calcium, as in the Grenville series. This is a modern instance analogous to that suggested above. Hence all these minerals filling the cavities and canals of Eozoon may have been deposited by water at ordinary temperatures, and have no connection with the alteration to which the beds have been subsequently subjected.

I may add here that a Tertiary glauconite from 
the Calcaire Grossier of Paris analysed by Berthier ${ }^{1}$ is essentially a serpentine composed of silicate of iron and magnesia, that Loganite as analysed by Hunt contains thirty-one per cent. of magnesia, and that Hoskins has shown ${ }^{2}$ that modern glauconites often contain large proportions of magnesia and equivalent bases.

It is also to be observed that independently of volcanic debris the reports of the Challenger expedition show that in the deep seas the decay of organic matter causes an alkaline condition of the sediments leading to the formation of alkaline silicates, while the presence of decaying volcanic dust furnishes the basis, whether of iron, alumina, or magnesia, necessary for the making up of glauconite. I have also suggested that the assimilation by Protozoa making calcareous skeletons, of the matter of Diatoms or humble plants having soluble silica in their organization or of silicious Protozoa, and sponge germs, must set free much soluble silica as a rejected or excrementitious matter which may contribute to the same result.

1 Beudant, Mineralogie, xi. 178.

2 Geological Magazine, July, I 895. 
It is much more likely that the serpentine of the Laurentian limestones was produced in these ways than that it resulted from the hydration of magnesian minerals after the rock was consolidated. In the former case it would be in the most favourable conditions for mineralizing organisms as glauconites do in the modern seas. In the latter it would cause disturbances and changes of volume of which we have no evidence.

We thus find that the chemistry of the modern seas and that relating to the preservation of fossils of various ages by silicious infiltrations lends great probability to the belief that serpentine played this rôle in the olclest seas, though it would seem that dolomite was more suitable to the filling of the extremities of the minute tubes and their finer terminations. ${ }^{1}$

(3) Our third question leads to the inquiry in what modern or ancient marine animals we can find structures akin to those of our supposed

1 I have shown also that in the limestone containing Eozoon we find layers holding concretions of serpentine alternating with others holding crystals of dolomite, as if there were at some times conditions favourable to the deposition of silicate of magnesia, and at others to that of the carbonate. 
Laurentian fossil. The first analogy which suggested itself to Sir W. Logan, and a very natural one, was that to the so-called layer-corals (Figs. 43 to 45 ) that abound in the Silurian, Ordovician, and Cambrian rocks, and which though undoubtedly

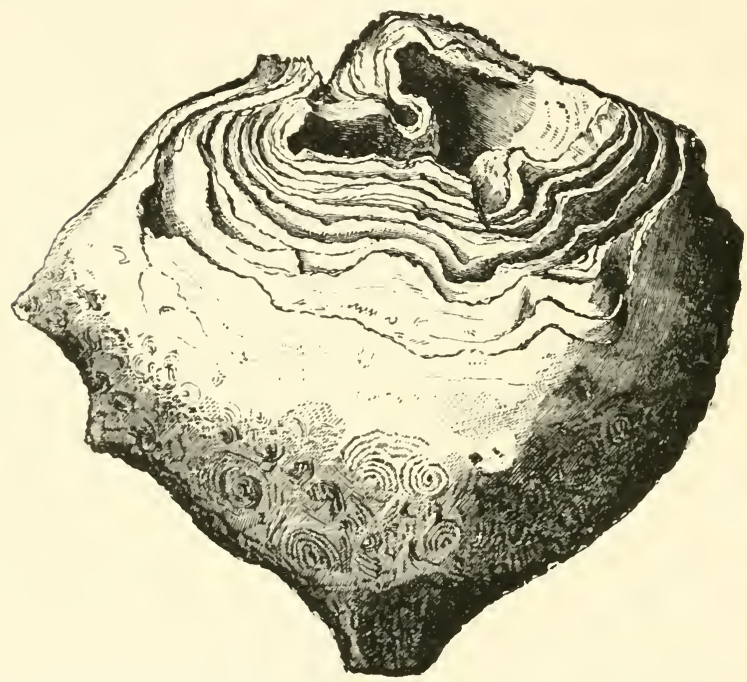

FIG. 43. - Stromatocerium rugosum, Hall, Ordovician.

fossil animals, have proved very difficult to interpret or to assign to any known group. At first vaguely associated with the true corals, they were subsequently regarded as probably of more simple character, and as gigantic Protozoa; and later 
strong reasons have been assigned for giving them an intermediate place, as allied to those curious communities of humble animals possessing simple
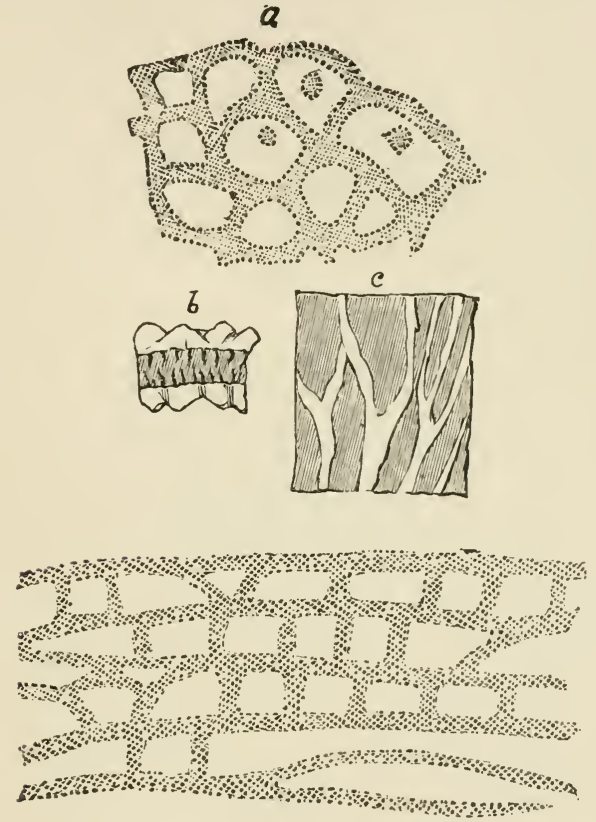

FIG. 44.-Structures of Stromatofora.

(a) Portion of oblique section. (b) Wall with pores, and coated with crystals of quartz. (c) Thickened portion of wall with canals. (d) Laminæ and pillars.

stomachs and prehensile tentacles (Hydroids) which form some of the simpler corals (Millepores, etc.), and the crusts (Hydractinix) which cover dead shells and other bodies in the sea. When examined 
microscopically, however, they differ very much among themselves, and it may be that some of them were Hydroids and some Protozoa. The oldest that we at present know, and consequently the nearest in time to Eozoon, impress us rather with the latter affinity. They are the fossils of the genus Cryptozoon of Hall (Fig. $7^{1}$ ), which form great masses filling certain beds of Upper Cambrian age,

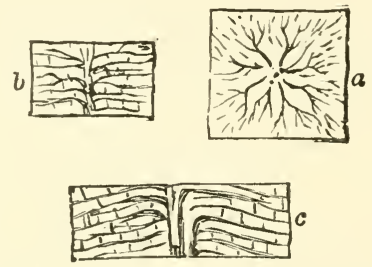

FIG. 45.-Tubular Struuure of Canostroma, Silurian. and which, when sliced and studied microscopically, are found to consist of concentric thin laminæ filled in between with a porous mass of calcareous matter penetrated by an infinity of tortuous tubes. Forms of this kind have been traced downward into preCambrian beds in Colorado, and as we shall find in New Brunswick, into the Upper Laurentian itself. They present, however, structural differences from

${ }^{1}$ See Figs. 7 and 8, pp. 37, 39; also Fig. 8 and Microscopic slice, Fig. 6I, at end. 
Eozoon, which rather conforms to the arrangements found in some Protozoa of smaller size, and which, under the name of Foraminifera, have abounded in all geological periods, and are excessively abundant in the modern ocean. They may be defined as animals composed of a soft and apparently homogeneous animal jelly known as protoplasm or sarcode. When carefully examined, however, it is found to have a granular texture and to be divisible into two layers, an outer and an inner, while it possesses a little hollow vessel capable of expanding and absorbing the liquid matter of the enclosing protoplasm, and of contracting so as to expel its contents. This seems to be the only organ of circulation and excretion. There are, however, small cells or reproductive bodies in the interior, varying in number, size, and development in different forms. The most remarkable property of these creatures is that of stretching out from the surface of the body threads or projections of the protoplasm, ${ }^{1}$ often of considerable length, and which serve at once as organs of locomotion and prehension. These creatures are in

1 Known as Pseudopodia. 
some respects the simplest of animals, yet in other respects they present strange complexities. This
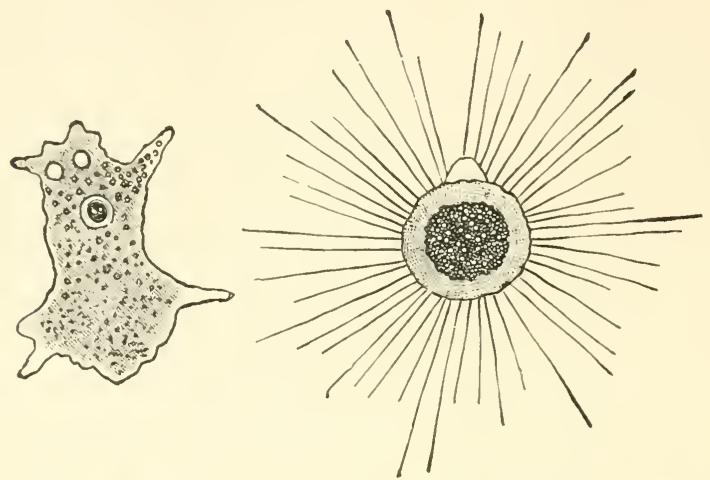

Amaba.

\section{Actinophrys.}

From original sketches.

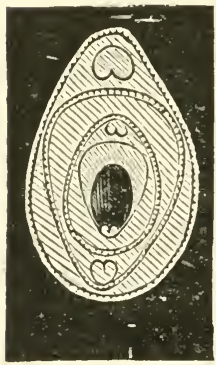

Biloculina. A many-chambered Foraminifer. Magnified as a transparent object.

Fig. 46.-Recent Protozoa.

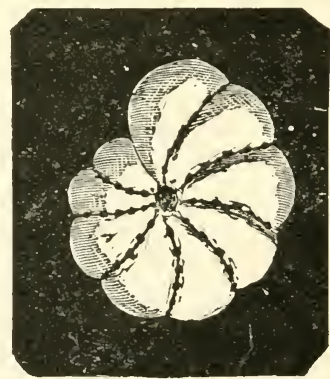

Polystomella. A spiral Foraminifer. Magnified as an opaque object.

is more especially evident in their tests or coverings, made for the most part of limestone or calcium carbonate, but sometimes of grains of fine 
sand cemented together. These coverings are always perforated with at least one orifice for the emission of the thread-like processes or pseudopods, and often with a vast number of small pores for the same purpose. Sometimes the test or shell is smooth, sometimes beautifully sculptured externally. Sometimes it consists of a single chamber like a ball or vase. More often, as the animals increase in size, they form additional chambers, and the body thus becomes divided into lobes connected with each other by necks passing through orifices in the partitions. The chambers are arranged in rows or in spirals, and in other ways, giving a vast variety of forms, often presenting the most beautiful patterns executed in the purest white marble, and the ornamental parts constitute thickenings of the walls giving greater strength, and are penetrated with microscopic canals communicating with the soft substance of the animal.

These creatures abound in all parts of the ocean, from the surface to the greatest depths. The Foraminifera have also existed from the earliest geological times, and in all the long ages of the earth's history seem to have retained the same structures and even ornamentation; so that species 
from very old geological formations are often scarcely distinguishable from those now living, and must have played precisely the same parts in the system of nature. One of these functions is that of accumulating great thicknesses of calcareous matter in the sea-bottom.

The manner in which such accumulation takes place we learn from what is now going on in the ocean, more especially from the result of the recent deep-sea dredging expeditions. The Foraminifera are vastly numerous, both near the surface and at the bottom of the sea, and multiply rapidly; and as successive generations die, their shells accumulate on the ocean bed, or are swept by currents into banks, and thus in process of time constitute thick beds of white chalky material, which may eventually be hardened into limestone. This process is now depositing a great thickness of white ooze in the bottom of the ocean; and in times past it has produced such vast thicknesses of calcareous matter as the chalk and the nummulitic limestone of Europe and the orbitoidal limestone of America. The chalk, which alone attains a maximum thickness of $I, 000$ feet, and, according to Lyell, can be traced across Europe for I,IOO 
geographical miles, may be said to be entirely composed of shells of Foraminifera imbedded in a paste of still more minute calcareous bodies, the Coccoliths, which are probably products of marine vegetable life, if not of some animal organism still simpler than the Foraminifera.

There are, however, some sessile examples of these animals which attain to larger dimensions than the free and locomotive forms. As an example of these we may take the Polytrema, which forms little hard red lumps on West Indian corals. Such a creature, beginning life as a little round spot of protoplasm, almost invisible, and protected with a little dome of carbonate of lime for the extension of its pseudopods as it grows in size, adds chamber to chamber in successive tiers till it assumes an appreciable size, all the chambers communicating with each other, while the outer ones are perforated with pores for extension of the pseudopods. In one form (Carpenteria) the same end is secured by leaving an open space in the middle of the conical mass like the crater of a small volcano. It is with these larger and sessile forms that we must compare Eozoon, though some of its minute structures rather resemble those of some smaller types. 
All the creatures referred to above, notwithstanding the differences in their skeletons, resemble each other very closely in their soft parts, and come under the general name of Foraminifera, a name having reference to the openings by which the animal matter within communicates with the water without, for nutrition and respiration. Such creatures may be regarded as the simplest and most ready media for the conversion of vegetable matter into animal tissues, and their functions are almost entirely limited to those of nutrition. Hence it is likely that they will be able to appear in the most gigantic forms under such conditions as afford them the greatest amount of pabulum for the nourishment of their soft parts and for their skeletons. There is reason to believe, for example, that the occurrence, both in the chalk and the deep-sea mud, of immense quantities of the minute oval bodies known as Coccoliths along with Foraminifera, is not accidental. The Coccoliths appear to be grains of calcareous matter formed in minute plants adapted to a deep-sea habitat; and these, along with the vegetable and animal debris constantly being derived from the death of the living things at the surface, and falling to the bottom, afford the material both of sarcode and 
shell. Now if the Laurentian graphite represents an exuberance of vegetable growth in those old seas proportionate to the great supplies of carbonic acid in the atmosphere and in the waters, and if the Eozoic ocean was even better supplied with carbonate of lime than those Silurian seas whose vast limestones bear testimony to their richness in such material, we can easily imagine that the conditions may have been more favourable to a creature like Eozoon than those of any other period of geological time.

Growing, as Eozoon may be supposed to have done, on the floor of the ocean, and covering wide patches with more or less irregular masses, it must have thrown up from its whole surface its pseudopods to seize whatever floating particles of food the waters carried over it. There is also reason to believe, from the outline of certain specimens, that it often grew upward in inverted, conical, or club-shaped forms, and that only the broader patches were penetrated by the tubes or oscula already mentioned, admitting the sea-water deeply into the substance of the masses. In this way its growth might be rapid and continuous; but it does not seem to have possessed the power 
of growing indefinitely by new and living layers covering those that had died, in the manner of some corals. Its life seems to have had a definite termination, and when that was reached, an entirely new colony had to be commenced. In this it had more affinity with the Foraminifera, as we now know them, than with the corals, though practically it had the same power with the coral polyps of accumulating limestone in the sea-bottom, a power indeed still possessed by its foraminiferal successors. In the case of coral limestones, we know that a large proportion of these consist, not of continuous reefs, but of fragments of coral mixed with other calcareous organisms, spread usually by waves and currents in continuous beds over the sea-bottom. In like manner we find in the limestones containing Eozoon, layers of fragmental matter which shows in places the characteristic structures, and which evidently represents the debris swept from the Eozoon masses and reefs by the action of the waves. With this fragmental matter small rounded organisms to be noticed in the sequel occur ; and while they may be distinct animals resembling the smaller modern species, they may also be the fry of Eozoon, or small portions of its acervuline upper surface floated off in a living 
state, and possibly capable of living independently and of founding new colonies.

It is only by a somewhat wild poetical licence that Eozoon has been represented as a "kind of enormous composite animal stretching from the shores of La-

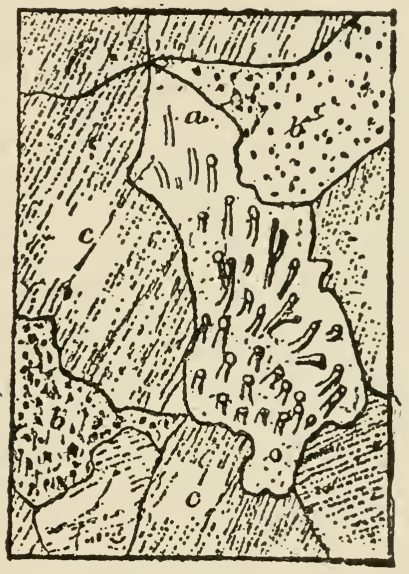

FIG. 47.-Slice of Limestone (magnified).

(a) Fragment of Eozoon with canals. (b) Fragments of granular calcite, probal ly organic. (c) Structureless calcite with cleavage lines (Côte St. Pierre).

brador to Lake Superior, and thence northward and southward to an unknown distance, and forming masses I,500 feet in depth." We may discuss byand-by the question of the composite nature of masses of Eozoon, and we see in the corals evidence of the great size to which composite animals of a 
higher grade can attain. In the case of Eozoon we must imagine an ocean floor more uniform and level than that now existing. On this the organism would establish itself in spots and patches. These might finally become confluent over large areas, just as massive corals do. As individual masses attained maturity and died, their pores would be filled up with limestone or silicious deposits, and thus could form a solid basis for new generations, and in this way limestone to an indefinite extent might be produced. Further, wherever such masses were high enough to be attacked by the breakers, or where portions of the sea-bottom were elevated, the more fragile parts of the surface would be broken up and scattered widely in beds of fragments over the bottom of the sea, while here and there beds of mud or sand or of volcanic debris would be deposited over the living or dead organic mass, and would form the layers of gneiss and other schistose rocks interstratified with the Laurentian limestone. In this way, in short, Eozoon would perform a function combining that which corals and Foraminifera perform in the modern seas; forming both reef limestones and extensive chalky beds, and probably living both in the shallow and the deeper parts of 
the ocean. If in connection with this we consider the rapidity with which the soft, simple, and almost structureless sarcode of these Protozoa can be built up, and the probability that they were more abundantly supplied with food, both for nourishing their soft parts and skeletons, than any similar creatures in later times, we can readily understand the great volume and extent of the Laurentian limestones which they aided in producing. I say aided in producing, because I would not desire to commit myself to the doctrine that the Laurentian limestones are wholly of this origin. There may have been other animal limestone-builders than Eozoon, and there may have been limestones formed by plants like the modern Nullipores or by merely mineral deposition.

Its relations to modern animals of its type have been very clearly defined by Dr. Carpenter. In the structure of its proper wall and its fine parallel perforations, it resembles the Nummulites and their allies (Figs. 48, 49); and the organism may therefore be regarded as an aberrant member of the Nummuline group, which affords some of the largest and most widely distributed of the fossil Foraminifera. This resemblance may be seen in Fig. 48. To the 
Nummulites it also conforms in its tendency to form a supplemental or intermediate skeleton with canals,

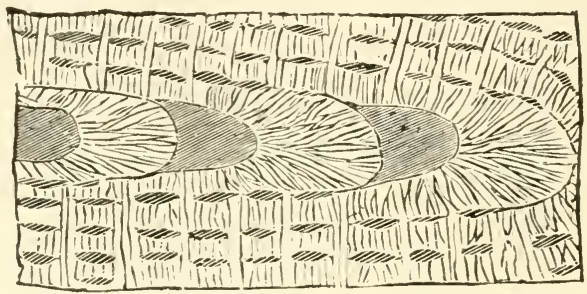

FIG. 48. - Section of a Nummulite, from Eocene Limestone of Syria. Showing chambers, tubuli, and canals. Compare this and Fig. 49 with Figs. 28 and 29 .

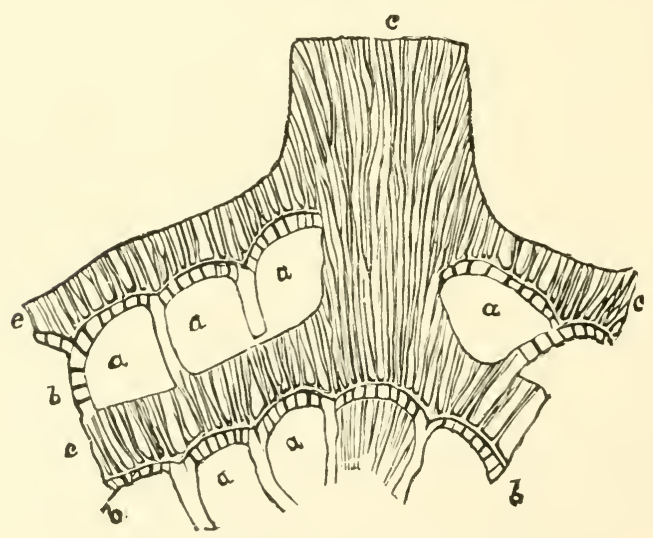

FIG. 49.-Fortion of Shell of Calcarina.

Magnified, after Carpenter. (a) Cells. (b) Original cell-wall with tubull. (c) Supplementary skeleton with canals.

though the canals themselves in their arrangement more nearly resemble Calcarina, which is represented 
in Fig. 49. In its superposition of many layers, and in its tendency to a heaped-up or acervuline irregular growth it resembles Carpenteria, Polytrema and Tinoporus, forms of a different group in so far as shellstructure is concerned. The large and curious sandy Foraminifer from the Pacific dredged by Alexander Agassiz, and named by Goës, Neusina Agassizii, may also be mentioned as presenting some points of resemblance. ${ }^{1}$ It may thus be regarded as a composite type, combining peculiarities now observed in two groups, or it may be regarded as a representative in the Nummuline series of Polytrema and Tinoporus in the Rotaline series. At the time when Dr. Carpenter stated these affinities, it might be objected that Foraminifera of these families are in the main found in the Modern and Tertiary periods. Dr. Carpenter has since shown that the curious oval Foraminifer called Fusulina, found in the coal formation, is in like manner allied to both Nummulites and Rotalines; and still more recently Mr. Brady has discovered a true Nummulite in the Lower Carboniferous of Belgium. This group being now fairly brought down to the Palæozoic, we may

1 Bulletin Mus. Comp. Zoology, vol. xxiii., No. 5, Dec., 1892. 
hope finally to trace it back to the Primordial, and thus to bring it still nearer to Eozoon in time.

Though Eozoon was probably not the only animal of the Laurentian seas, yet it was in all likelihood the most conspicuous and important as a collector of calcareous matter, filling the same place afterwards occupied by the reef-building corals. Though probably less efficient than these as a constructor of solid limestones, from its less permanent and continuous growth, it formed wide floors and patches on the seabottom, and when these were broken up vast quantities of limestone were formed from their debris. It must also be borne in mind that Eozoon was not everywhere infiltrated with serpentine or other silicious minerals; quantities of its substance were merely filled with carbonate of lime, resembling the chamber-wall so closely that it is nearly impossible to make out the difference, and thus is likely to pass altogether unobserved by collectors, and to baffle even the microscopist. Although therefore the layers which contain well-characterized Eozoon are few and far between, there is reason to believe that in the composition of the limestones of the Laurentian it bore no small part ; and as these limestones are some of them several hundreds of feet in 
thickness, and extend over vast areas, Eozoon may be supposed to have been as efficient a world-builder as the Stromatopora of the Silurian and Devonian, the Globigerinæ and their allies in the chalk, or the Nummulites and Miliolites in the Eocene. It is a remarkable illustration of the constancy of natural causes and of the persistence of animal types, that these humble Protozoans, which began to secrete calcareous matter in the Laurentian period, have been continuing their work in the ocean through all the geological ages, and are still busy in accumulating those chalky muds with which recent dredging operations in the deep sea have made us so familiar. 

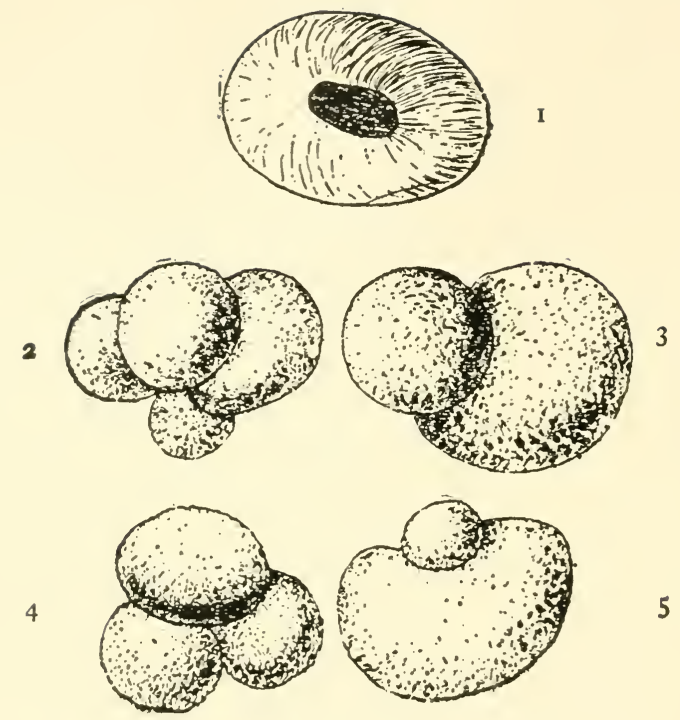

FIG. 50.-Figures of Archaospherine.

(x) Specimen with tubulated wall. (2 to 5) Casts in serpentine, Côte St. Pierre and Long Lake 
CONTEMPORARIES OF EOZOON 



\section{VIII}

CONTEMPORARIES OF EOZOON

$7 \begin{array}{r}\mathrm{HE} \text { name Eozoon, or Dawn-animal, raises the } \\ \text { question whether we shall ever know any }\end{array}$ earlier representative of animal life. Here I think it necessary to explain that in suggesting the name Eozoon for the earliest fossil, and Eozoic for the formation in which it is contained, I had no intention to affirm that there may not have been precursors of the Dawn-animal. By the similar term, Eocene, Lyell did not mean to affirm that there may not have been modern types in the preceding geological periods: and so the dawn of animal life may have had its grey or rosy breaking at a time long anterior to that in which Eozoon built its marble reefs. When the fossils of this early auroral time shall be found, it will not be hard to invent appropriate names for them. There are, however, two reasons that give propriety to the name in the present state of our knowledge. One is, that the Laurentian rocks are absolutely the oldest that have yet come under the 
notice of geologists, and at the present moment it seems extremely improbable that any older sediments exist, at least in a condition to be recognised as such. The other is that Eozoon, as a member of the group Protozoa, of gigantic size and comprehensive type, and oceanic in its habitat, is as likely as any other creature that can be imagined to have been the first representative of animal life on our planet. Vegetable life may have preceded it, nay probably did so by at least one great creative æon, and may have accumulated previous stores of organic matter; but if any older forms of animal life existed, it is certain at least that they cannot have belonged to much simpler or more comprehensive types. It is also to be observed that such forms of life, if they did exist, may have been naked protozoa, which may have left no sign of their existence except a minute trace of carbonaceous matter, and perhaps not even this.

But if we do not know, and perhaps are not likely to know, any animals older than Eozoon, may we not find traces of some of its contemporaries, either in the Eozoon limestones themselves, or other rocks associated with them? Here we must admit that a deep-sea Foraminiferal limestone may give a very 
imperfect indication of the fauna of its time. A dredger who should have no other information as to the existing population of the world, except what he could gather from the deposits formed under several hundred fathoms of water, would necessarily have very inadequate conceptions of the matter. In like manner a geologist who should have no other information as to the animal life of the Mesozoic ages than that furnished by some of the thick beds of white chalk, might imagine that he had reached a period when the simplest kinds of protozoa predominated over all other forms of life; but this impression would at once be corrected by the examination of other deposits of the same age: so our inferences as to the life of the Laurentian from the contents of its oceanic limestones may be very imperfect, and it may yet yield other and various fossils. Its possibilities are, however, limited by the fact that before we reach this great depth in the earth's crust, we have already left behind in much newer formations all traces of animal life except a few of the lower forms of aquatic invertebrates; so that we are not surprised to find only a limited number of living things, and those of very low type. Do we then know in the Laurentian even a few distinct species, 
or is our view limited altogether to Eozoon Canadense? In answering this question, we must bear in mind that the Laurentian itself was of vast duration, and that important changes of life may have taken place even between the deposition of the Eozoon limestones and that of those rocks in which we find the comparatively rich fauna of the Primordial age. This subject was discussed by the writer as early as I 865 , and I may repeat here what could be said in relation to it at that time :-

"In connection with these remarkable remains, it appeared desirable to ascertain, if possible, what share these or other organic structures may have had in the accumulation of the limestones of the Laurentian series. Specimens were therefore selected by Sir W. E. Logan, and slices were prepared under his direction. On microscopic examination, a number of these were found to exhibit merely a granular aggregation of crystals, occasionally with particles of graphite and other foreign minerals, or a laminated mixture of calcareous and other matters, in the manner of some more modern sedimentary limestones. Others, however, were evidently made up almost entirely of fragments of Eozoon, or of mixtures of these with other calcareous and carbon- 
aceous fragments which afford more or less evidence of organic origin. The contents of these organic limestones may be considered under the following heads :-

I. Remains of Eozoon.

2. Other calcareous bodies, probably organic.

3. Objects imbedded in the serpentine.

4. Carbonaceous matters.

"(I) The more perfect individuals of Eozoon do not constitute the mass of any of the larger specimens in our collections; but considerable portions of some of them are made up of material of similar minute structure, destitute of lamination, and irregularly arranged. Some of this material gives the impression that there may have been organisms similar to Eozoon, but growing in an irregular or acervuline manner without lamination. Of this, however, I cannot be certain; and, on the other hand, there is distinct evidence of the aggregation of fragments of Eozoon in some of these specimens. In some they constitute the greater part of the mass. In others they are imbedded in calcareous matter of a different character, or in serpentine or granular pyroxene. In most of the specimens the cells of the fossils are more or less filled with these minerals; and in some 
instances it would appear that the calcareous matter of fragments of Eozoon has been in part replaced by serpentine."

[I may add here that in the limestone at Côte St. Pierre there are in some of the beds successive laminæ with grains of serpentine and others with crystals of dolomite, and that both contain fragments of Eozoon. It thus seems as if the magnesia associated with the limestone, at some stages of deposition took the form of silicate, and in others that of carbonate. I may also observe here that I have detected fragments of Eozoon in Laurentian limestone from New Brunswick, from Chelmsford in Massachusetts, from Warren County, New York, from Brazil, and from the Alps.]

"(2) Intermixed with the fragments of Eozoon above referred to are other calcareous matters apparently fragmentary. They are of various angular and rounded forms, and present several kinds of structure. The most frequent of these is a strong lamination varying in direction according to the position of the fragments, but corresponding, as far as can be ascertained, with the diagonal of the rhombohedral cleavage. This structure, though crystalline, is highly characteristic of crinoidal remains when preserved in 
altered limestones. The more dense parts of Eozoon, destitute of tubuli, also sometimes show this structure, though less distinctly. Other fragments are compact and structureless, or show only a fine granular appearance ; and these sometimes include grains, patches, or fibres of graphite. In Cambro-Silurian limestones, fragments of corals and shells which have been partially infiltrated with bituminous matter, show a structure like this. On comparison with altered organic limestones of the Cambro-Silurian system, these appearances would indicate that, in addition to the debris of Eozoon, other calcareous structures, more like those of crinoids, corals, and shells, have contributed to the formation of the Laurentian limestones.

"(3) In the hydrous silicate (Loganite) filling the chambers of a large specimen of Eozoon from Burgess, there are numerous small pieces of foreign matter; and the silicate itself is laminated, indicating its sedimentary nature. Some of the included fragments appear to be carbonaceous, others calcareous; but no distinct organic structure can be detected in them. There are, however, in the Loganite, many minute silicious grains of a bright green colour, resembling greensand concretions; and the 
manner in which these are occasionally arranged in lines and groups suggests the supposition that they may possibly be casts of the interior of minute Foraminiferal shells. They may, however, be concretionary in their origin (Fig. 5I).

"(4) In some of the Laurentian limestones submitted to me by Sir W. E. Logan, and in others from Arnprior on the Ottawa, there are fibres and granules

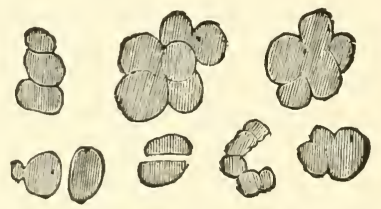

Fig. 51.-Archaospherina from Burgess Eozoon. Grains included in Loganite.

(Magnified.)

of carbonaceous matter which do not conform to the crystalline structure, and present appearances quite similar to those which in more modern limestones result from the decomposition of the algæ, etc. Though retaining mere traces of organic structure, little doubt would be entertained as to their vegetable origin if they were found in fossiliferous limestones. In limestones of Upper Laurentian age, near St. John, New Brunswick, more distinct fibres occur, and 
associated with these beds Matthew has found what seem to be spicules of sponges, some simple and others hexactinelled like those of Protospongia of the Cambrian.

Though the abundance and wide distribution of Eozoon, and the important part it seems to have acted in the accumulation of limestone, indicate that it was one of the most prevalent forms of animal existence in the seas of the Laurentian period, the non-existence of other organic beings is not implied. On the contrary, independently of the indications afforded by the limestones themselves, it is evident that in order to the existence and growth of these large Rhizopods, the waters must have swarmed with more minute animal or vegetable organisms on which they could subsist. On the other hand, though this is a less certain inference, the dense calcareous skeleton of Eozoon may indicate that it also was liable to the attacks of animal enemies. It is also possible that the growth of Eozoon or the deposition of the serpentine and pyroxene in which its remains have been preserved, or both, may have been connected with certain oceanic depths and conditions, and that we have as yet revealed to us the life of only certain stations in the Laurentian seas. Whatever conjec- 
tures we may form on these more problematic points, the observations above detailed appear to establish the following conclusions :-

First, that in the Laurentian period, as in subsequent geological epochs, the Rhizopods were important agents in the accumulation of beds of limestone; and secondly, that in this early period these low forms of animal life attained to a development, in point of magnitude and complexity, unexampled, in so far as yet known, in the succeeding ages of the earth's history. This early culmination of the Rhizopods is in accordance with one of the great laws of the succession of living beings, ascertained from the study of the introduction and progress of other groups; and, should it prove that these great Protozoans were really the dominant type of animals in the Laurentian period, this fact might be regarded as an indication that in these ancient rocks we may actually have the records of the first appearance of animal life on our plaret.

With reference to the first of the above heads, I have now to state that it seems quite certain that the upper and younger portions of the masses of Eozoon often passed into the acervuline form, and the period in which this change took place seems to have de- 
pended on circumstances. In some specimens there are only a few regular layers, and then a heap of irregular cells. In other cases a hundred or more regular layers were formed; but even in this case little groups of irregular cells occurred at certain points near the surface. I have also found some masses clearly not fragmental which consist altogether of acervuline cells. A specimen of this kind is represented in Fig. 52. It is oval in outline, enclosed in a nodule of serpentine, about three inches in length, wholly made up of rounded or cylindrical cells, the walls of which have a beautiful tubular structure, but there is little or no supplemental skeleton. Whether this is a portion accidentally broken off from the top of a mass of Eozoon, or a peculiar varietal form, or a distinct species, it would be difficult to determine. In the meantime I have described it as a variety, "acervulina," of the species Eozoon Canadense. It admits of comparison with a fragment figured by Dr. Carpenter, which he compares with the chamberlets and tubes of Nummulites lavigata of the Eocene. ${ }^{1}$ Another variety also, from Petite Nation, shows

1 Proceedings of Geolosical Society, 1875. 
extremely thin laminæ, closely placed together and very massive, and with little supplemental skeleton. This may be allied to the last, and may be named variety "minor." 1

All this, however, has nothing to do with the layers of fragments of Eozoon which are scattered through the Laurentian limestones. In these the fossil is sometimes preserved in the ordinary manner, with its cavities filled with serpentine, and the thicker parts of the skeleton having their canals filled with this substance. In this case the chambers may have been occupied with serpentine before it was broken up. At St. Pierre there are distinct layers of this kind, from half an inch to several inches in thickness, regularly interstratified with the ordinary limestone. In other layers no serpentine occurs, but the interstices of the fragments are filled with crystalline dolomite or magnesian limestone, which has also penetrated the canals; and there are indications, though less manifest, that some at least of the layers of pure limestone are composed of fragmental Eozoon. In the Laurentian limestone of Wentworth,

${ }^{1}$ Annals and Magazine of Natural History, Ser. 4, vol. xiii. p. 457. 

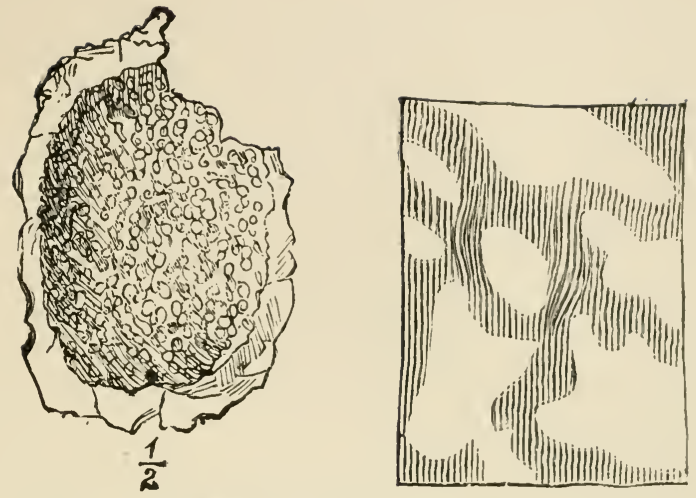

Fig. 52.-Acervuline Variety of Eozoon, Côte St. Pierre.

(a) General form, half natural size. (b) Portion of cellular interior, magnified, showing the course of the tubuli.

a
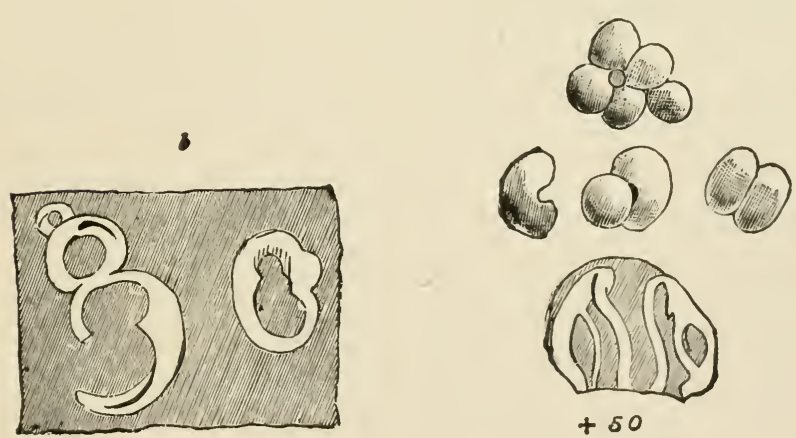

$+50$

FIG. 53.-Archaospherina from Cote St. Pierre.

(a) Specimens dissolved out by acid, the lower one showing interior septa. (b) Specimens seen in section. 

belonging apparently to the same band with that of St. Pierre, there are many small rounded pieces of limestone, evidently the debris of some older rock, broken up and rounded by attrition. In some of these fragments the structure of Eozoon may be plainly perceived. This shows that still older limestones composed of Eozoon were at that time undergoing waste, and carries our view of the existence of this fossil back to the very beginning of the Grenville series of the Laurentian.

With respect to organic fragments not showing the structure of Eozoon, I have not as yet been able to refer these to any definite origin. Some of them may be simply thick portions of the shell of Eozoon with their pores filled with calcite, so as to present a homogeneous appearance. Others have much the appearance of fragments of such Primordial forms as Archceocyathus, now usually regarded as corals or sponges; but after much careful search, I have thus far been unable to say more than I could say in 1865.

It is different, however, with the round cells infiltrated with serpentine and with the silicious grains included in the loganite. Fig. 53 shows such bodies found mixed with fragmental Eozoon and in sepa- 
rate thin layers at Côte St. Pierre. In Fig. 5I I have shown some of the singular grains found in the loganite occupying the chambers of Eozoon from Burgess, and in Fig. 54 some remarkable forms of this kind found in the limestones of Long

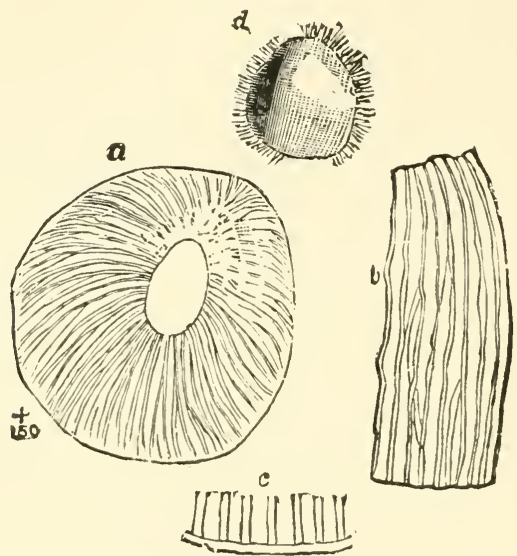

Fig. 54.-Archaospherina from Long Lake Limestone. (Magnified.)

(a) Single cell, showing tubulated wall. $(b, c)$ Portions of same more highly magnified. (d) Casts decalcified, and showing casts of tubules.

Lake and Wentworth. All these, I think, are essentially of the same nature, namely, chambers originally invested with a tubulated wall like Eozoon, and aggregated in groups, sometimes in a linear manner, sometimes spirally, like those Globigerinæ which constitute the mass of modern deep- 
sea dredgings and also of the chalk. These bodies occur dispersed in the limestone, arranged in thin layers parallel to the bedding or sometimes in the large chamber-cavities of Eozoon. They are so variable in size and form that it is not unlikely they may be of different origins. The most probable of these may be thus stated. First, they may in some cases be the looser superficial parts of the surface of Eozoon broken up into little groups of cells. Secondly, they may be few-celled germs or buds given off from Eozoon. This would correspond with what Carpenter, and more recently Brady and Lester, have observed in the case of some of the larger of the modern Foraminifera. Thirdly, they may be smaller Foraminifera, structurally allied to Eozoon, but in habit of growth resembling those little globe-shaped forms which, as already stated, abound in chalk and in the modern ocean. The latter view I should regard as highly probable in the case of many of them; and I have proposed for them, in consequence, and as a convenient name, Archaospherine, or ancient spherical animals.

Carbonaceous matter is rare in the true Eozoon limestones, and, as already stated, I would refer the Laurentian graphite or plumbago mainly to plants. 
Dr. Gümbel, the Director of the Geological Survey of Bavaria, is one of the most active and widely informed of European geologists, combining European knowledge with an extensive acquaintance with the larger and in some respects more typical areas of the older rocks in America, and stratigraphical geology with enthusiastic interest in the microscopic structures of fossils. $\mathrm{He}$ at once, and in a most able manner, took up the question of the application of the discoveries in Canada to the rocks of Bavaria. The spirit in which he did so may be inferred from the following extract :-

"The discovery of organic remains in the crystalline limestones of the ancient gneiss of Canada, for which we are indebted to the researches of Sir William Logan and his colleagues, and to the careful microscopic investigations of Drs. Dawson and Carpenter, must be regarded as opening a new era in geological science.

"This discovery overturns at once the notions hitherto commonly entertained with regard to the origin of the stratified primary limestones, and their accompanying gneissic and quartzose strata, included under the general name of primitive crystalline schists. It shows us that these crystalline 
stratified rocks, of the so-called primary system, are only a backward prolongation of the chain of fossiliferous strata; the elements of which were deposited as oceanic sediment, like the clay-slates, limestones, and sandstones of the Palrozoic formations, and under similar conditions, though at a time far more remote, and more favourable to the generation of crystalline mineral compounds.

"In this discovery of organic remains in the primary rocks, we hail with joy the dawn of a new epoch in the critical history of these earlier formations. Already in its light, the primeval geological time is seen to be everywhere animated, and peopled with new animal forms of whose very existence we had previously no suspicion. Life, which had hitherto been supposed to have first appeared in the Primordial division of the Silurian period, is now seen to be immeasurably lengthened beyond its former limit, and to embrace in its domain the most ancient known portions of the earth's crust. It would almost seem as if organic life had been awakened simultaneously with the solidification of the earth's crust."

Gümbel has described from limestones of Laurentian age in various parts of Europe forms referable 
to Eozoon or to Archæospherinæ, and I have found fragmental Eozoon in specimens collected by Favre in the supposed Archæan nucleus of the Alps.

Gümbel also found in the Finnish and Bavarian limestones knotted chambers, like those of Wentworth above mentioned (Fig. 55), which he regards as belonging to some other organism than Eozoon; and flocculi having tubes, pores, and reticulations which would seem to point to the presence of structures akin to sponges or possibly remains of

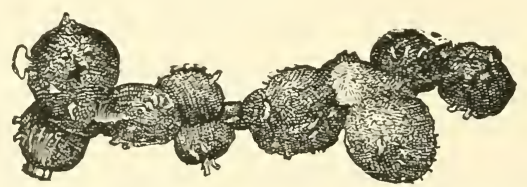

FIG. 55.-Archicospherine from Pargas in Finland. (After Gümbel.) (Magnified.)

seaweeds. These observations Gümbel has extended into other localities in Bavaria and Bohemia, and also in Silesia and Sweden, establishing the existence of Eozoon fossils in all the Laurentian limestones of the middle and north of Europe.

Gümbel has further found in beds overlying the older Eozoic series, and probably of the same age with the Canadian Huronian, a different species of Eozoon, with smaller and more contracted chambers, and still finer and more crowded canals. This, 
which is to be regarded as a distinct species, or at least a well-marked varietal form, he has named Eozoon Bavaricum (Fig. 56). Thus this early introduction of life is not peculiar to that old continent which we sometimes call the New World, but applies to Europe as well, and Europe has furnished a successor to Eozoon in the later Eozoic or

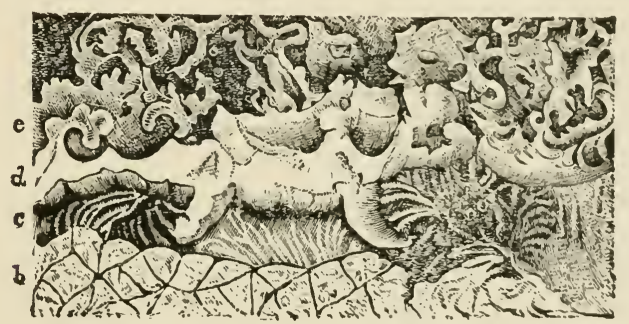

FIG. 56.-Sectinn of Evzoon Bavaricum, with Serpentine, from the Crystalline Limestone of the Hercynian primitive Clay-slate Formation at Hohenberg; 25 diameters (probably Huronian).

(a) Sparry carbonate of lime. (b) Cellular carbonate of lime. (c) System of tubuli. (d) Serpentine replacing the coarser ordinary variety. (e) Serpentine and hornblende replacing the finer variety, in the very much contorted portions.

Huronian period. In rocks of this age in America, after long search and much slicing of limestones, I have hitherto failed to find any decided foraminiferal remains other than the Tudor and Madoc specimens, which may be of this age. They are laminated forms resembling Eozoon, but I have reason to believe that their minute structure more 
closely resembles that of Cryptozoon, though it is somewhat obscure. If these are really Huronian and not Laurentian, the Eozoon from this horizon does not sensibly differ from that of the Lower Laurentian.

We are indebted to Mr. Matthew, of St. John, New Brunswick, who has so greatly distinguished himself by his discoveries in the Cambrian of that region, for some remarkable additions to the contemporaries of Eozoon. One of these is a laminated body, like Eozoon in its general appearance, but growing in crowded masses which by mutual pressure become columnar (Fig. 57). In the best preserved specimens each layer seems to consist of a thin lamina separated from its neighbours by a finely granular mass, traversed by innumerable irregular tubes. This recalls the structure of Cryptozoon of Hall, which, as we have seen, is found in pre-Cambrian rocks in Colorado, and abounds in the Upper Cambrian in New York, in Minnesota, and in different parts of Canada, but Archæozoon differs in its form and habit of growth. If the Stromatoporæ of the Ordovician and Silurian are hydroids, this may also be the case with Cryptozoon; but so far as its own structure is 
concerned, it approaches most nearly to the fossils known as Loftusia in the Carboniferous and later formations, and these are generally regarded

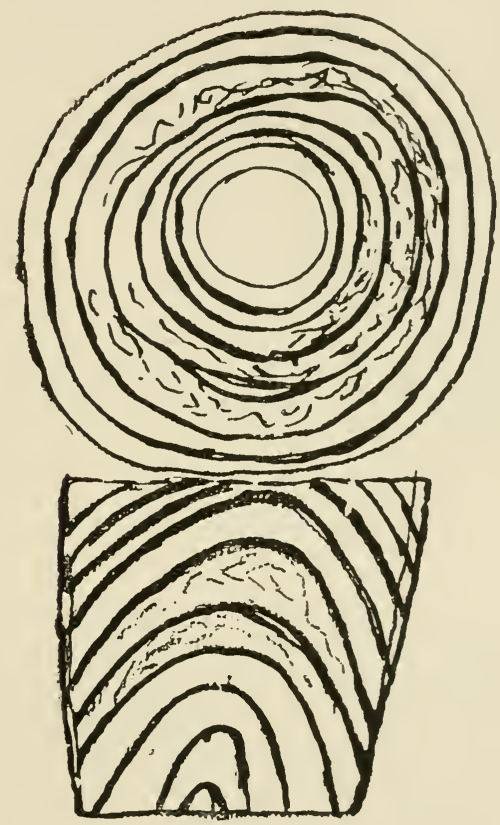

FIG. 57.-Archaozoon Acadiense, Matthew. Diagrammatic transverse and longitudinal sections of a small specimen.

Specimen in Peter Redpath Nuseum.

as Foraminiferal. We may thus have another giant Foraminiferal organism which contributed to the building up of rocks in the Laurentian seas. This discovery is also of importance as connecting 


\section{Pre-Palcozoic Rocks of Southern New Brunswick,} as tabulated by Matthew:-

\begin{tabular}{|c|c|c|c|}
\hline 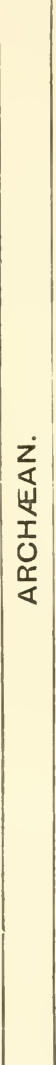 & 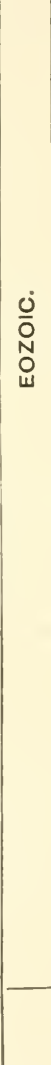 & 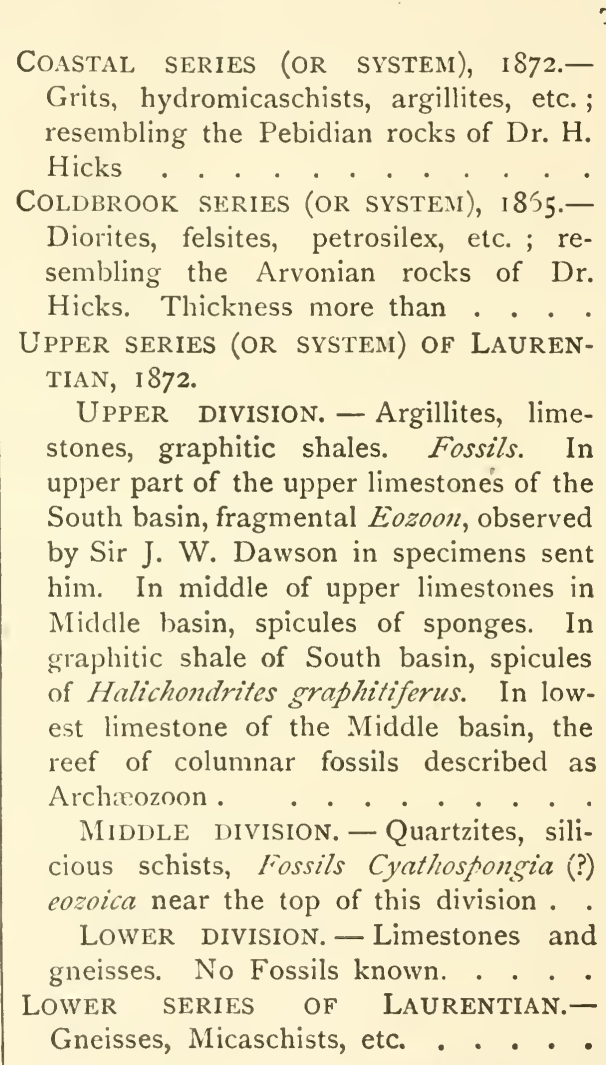 & $\begin{array}{l}10,000 \\
15,000^{1}\end{array}$ \\
\hline
\end{tabular}

1 The above thicknesses are on the authority of Dr. L. IW. Bailey. Report Progress Geological Survey Canada, I879, 

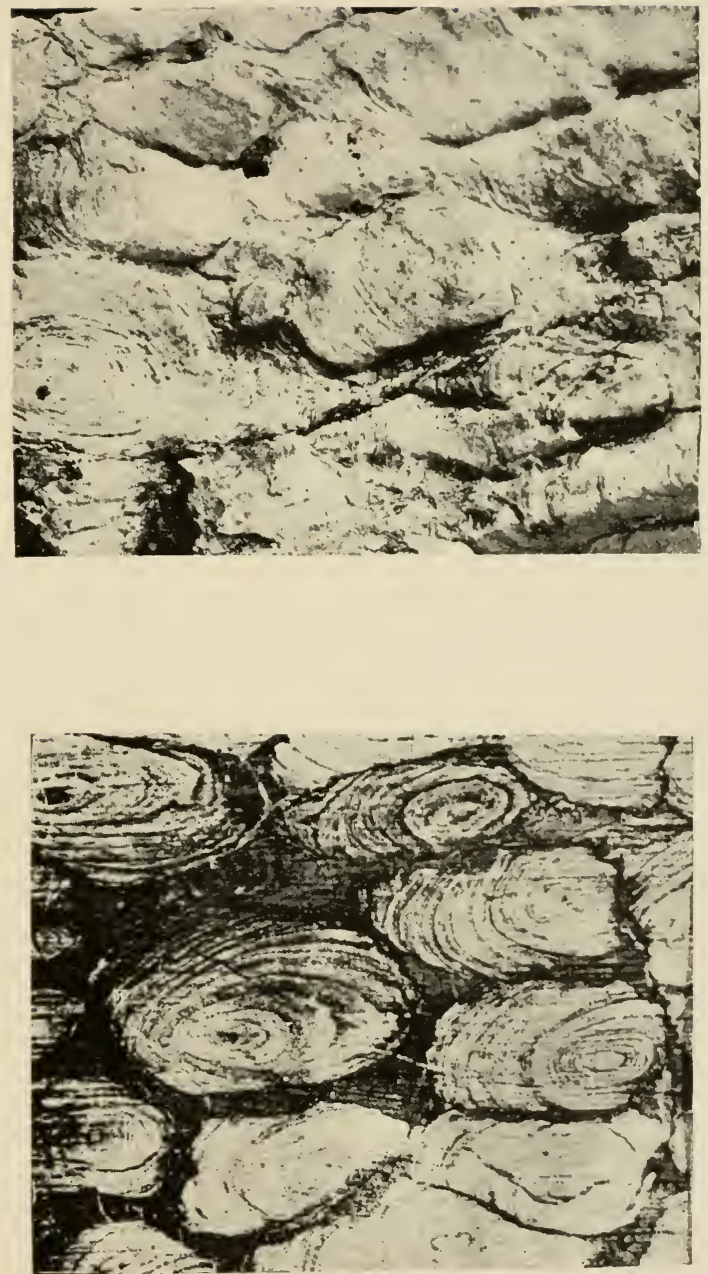

Eozoon through Cryptozoon with large organisms, probably Protozoa, extending upward to the top of the Cambrian, and thus forming a link of connection between the life of the Eozoic and that of the Palæozoic period. Matthew has also described forms which he regards as spicules of sponges from the Laurentian of New Brunswick. One of these seems to present cruciform needles forming square areas, like the Protospongia of Salter, from the Cambrian. The other has simple elongate needle-like spicules arranged in bundles. Matthew summarizes the rocks containing these fossils as in the table on p. 216, in descending order, the highest bed being below the Etcheminian. ${ }^{3}$ The first and second groups, it will be observed, are equivalent to the Huronian; the third corresponds to the Grenvillian, and the fourth to the Lower Laurentian.

pp. IO, D. D., and 21, D. D. Dr. R. W. Ells in the same Report, p. 6, D., describes these rocks, sixty miles east of St. John, as one system, with a thickness of i 4,000 feet.

${ }^{2}$ Fuller descriptions of these rocks may be found in Rep. Prog. Geol. Surv. of Canada, 1872, pp. 30, 34, etc.

${ }^{3}$ Bulletin Nat. Hist. Society of New Brunswick, 1890 where further details are given as to the fossils. 

IIFFICULTIES AND OBJECTIONS 



\section{IX}

DIFFICULTIES AND OBJECTIONS

THE active objectors to the animal nature of Eozoon have been few, though some of them have returned to the attack with a pertinacity and determination which would lead one to believe that they think the most sacred interests of science to be dependent on the annihilation of this proto-foraminifer. I do not propose here to treat of the objections in detail. I have presented the case of Eozoon on its own merits, and on these it must stand. I may merely state that the objectors strive to account for the existence of Eozoon by purely mineral deposition, and that the complicated changes which they require to suppose are perhaps the strongest indirect evidence for the necessity of regarding the structures as organic. The reader who desires to appreciate this may consult my memoir of I $888 .^{1}$

1 Also Rowney and King's papers in Journal Geological Society, August, 1866; and Proceedings Irish Academy, I870 and 1871 . 
I confess that I feel disposed to treat very tenderly the position of objectors. The facts I have stated make large demands on the faith of the greater part even of naturalists. Very few geologists or naturalists have much knowledge of the structure of foraminiferal shells, or would be able under the microscope to recognise them with certainty. Nor have they any distinct ideas of the appearances of such structures under different kinds of preservation and mineralization. Further, they have long been accustomed to regard the socalled Azoic or Archæan rocks as not only destitute of organic remains, but as being in such a state of metamorphism that these could not have been preserved had they existed. Few, therefore, are able intelligently to decide for themselves, and so they are called on to trust to the investigations of others, and on their testimony to modify in a marked degree their previous beliefs as to the duration of life on our planet. In these circumstances it is rather wonderful that the researches made with reference to Eozoon have met with so general acceptance, and that the resurrection of this ancient inhabitant of the earth has not aroused more of the sceptical tendency of our age. 
It must not be lost sight of, however, that in such cases there may exist a large amount of undeveloped and even unconscious scepticism, which shows itself not in active opposition, but merely in quietly ignoring this great discovery, or regarding it with doubt, as an uncertain or unestablished point in science. Such scepticism is especially to be expected on the part of the many enthusiastic students of petrography who are accustomed to regard rocks merely as mineral aggregates, and even to have their slices prepared in a manner which scarcely permits organic remains of present to be distinguished. Such students should consider that the discovery of Eozoon brings the rocks of the Laurentian system into more full harmony with the other geological formations. It explains the origin of the Laurentian limestones in consistency with that of similar rocks in the later periods, and in like manner it helps us to account for the graphite and sulphides and iron ores of these old rocks. It shows us that no time was lost in the introduction of life on the earth. Otherwise there would have been a vast lapse of time in which, while the conditions suitable to life were probably present, no living thing existed to 
take advantage of these conditions. Further, it gives a more simple beginning of life than that afforded by the more complex fauna of the Cambrian age; and this is more in accordance with what we know of the slow and gradual introduction of new forms of living things during the vast periods of Palæozoic time. In connection with this, it opens a new and promising field of observation in the older rocks; and if this should prove fertile, its exploration may afford a vast harvest of new forms to the geologists of the present and coming time. This result will be in entire accordance with what has taken place before in the history of geological discovery. I can myself remember a time when the old and semi-metamorphic sediments constituting the great Cambrian system were massed together in geological classifications as primitive or primary rocks, destitute or nearly destitute of organic remains. The brilliant discoveries of Sedgivick, Murchison, Barrande, and a host of others, have peopled these once barren regions; and they now stretch before our wondering gaze in the long vistas of early Palrezoic life. So we now look out from the Cambrian shore upon the ocean of the Etcheminian, the Huronian, 
and the Laurentian-all to us yet almost tenantless, except for the few organisms which, like stray shells cast upon the beach, or a far-off land dimly seen in the distance, incite to further researches, and to the exploration of the unknown treasures that still lie undiscovered. It would be a suitable culmination of the geological work of the last halfcentury, and one within reach at least of our immediate successors, to fill up this great blank, and to trace back the Primordial life to the stage of Eozoon, and perhaps even beyond this, to predecessors which may have existed at the beginning of the Laurentian, when the earliest sediments of that great formation were laid down. Vast unexplored areas of Laurentian and Huronian rocks exist in the Old World and the New. The most ample facilities for microscopic examination of rocks may now be obtained; and I could wish that one result of the publication of these pages may be to direct the attention of some of the younger and more active geologists to these fields of investigation. It is to be observed also that such regions are among the richest in useful minerals, and there is no reason why search for these fossils should not be connected with other 
and more practically useful researches. On this subject it will not be out of place to quote the remarks which I made in one of my earlier papers on the Laurentian fossils :-

"This subject opens up several interesting fields of chemical, biological, and geological inquiry. One of these relates to the conclusions stated by Dr. Hunt as to the probable existence of a large amount of carbonic acid in the Laurentian atmosphere, and of much carbonate of lime in the seas of that period, and the possible relation of this to the abundance of certain low forms of plants and animals. Another is the comparison already instituted by Professor Huxley and Dr. Carpenter, between the conditions of the Laurentian and those of the deeper parts of the modern ocean. Another is the possible occurrence of other forms of animal life than Protozoa, which I have stated in my paper of I864, after extensive microscopic study of the Laurentian limestones, to be indicated by the occurrence of calcareous fragments, differing in structure from Eozoon, but at present of unknown nature. Another is the effort to bridge over, by further discoveries [similar to those of Cryptozoon and Archæozoon], the gap now existing between 
the life of the Lower Laurentian and that of the Cambrian period. It is scarcely too much to say that these inquiries open up a new world of thought and investigation, and hold out the hope of bringing us into the presence of the actual origin of organic life on our planet, though this may perhaps be found to have been pre-Laurentian. I would here take the opportunity of repeating that, in proposing the name Eozoon for the first fossil of the Laurentian, and in suggesting for the period the name 'Eozoic,' I have by no means desired to exclude the possibility of forms of life which may have been precursors of what is now to us the dawn of organic existence. Should remains of still older organisms be found in those rocks now known to us only by pebbles in the Laurentian, these names will at least serve to mark an important stage in geological investigation."

But what if the result of such investigations should be to produce more sceptics, or to bring to light mineral structures so resembling Eozoon as to throw doubt upon the whole of the results detailed in these chapters? I can fancy that this might be the first consequence, more especially if the investigations were those of persons more conversant with 
rocks and minerals than with fossils; but I see no reason to fear the ultimate results. In any case, no doubt, the value of the researches hitherto made may be diminished. It is always the fate of discoverers in Natural Science, either to be followed by opponents who temporarily or permanently impugn or destroy the value of their new facts, or by other investigators who push on the knowledge of facts and principles so far beyond their standpoint that the original discoveries are cast into the shade. This is a fatality incident to the progress of scientific work, from which no man can be free; and in so far as such matters are concerned, we must all be content to share the fate of the old fossils whose history we investigate, and, having served our day and generation, to give place to others. If any part of our work should stand the fire of discussion, let us be thankful. One thing at least is certain, that such careful surveys as those in the Laurentian rocks of Canada which led to the discovery of Eozoon, and such microscopic examinations as those by which it has been worked up and presented to the public, cannot fail to yield good results of one kind or another. Already the attention excited by the controversies about Eozoon, 
by attracting invęstigators to the study of various microscopic and imitative forms in rocks, has promoted the advancement of knowledge, and must do so still more. For my own part, though I am not content to base all my reputation on such work as I have done with respect to this old fossil-which, indeed, was merely an interlude into which I was led by the urgency of my friend Logan-I am willing at least to take the responsibility of the results I have announced, whatever conclusions may be finally reached; and in the consciousness of an honest effort to extend the knowledge of nature, to look forward to a better fame than any that could result from the most successful and permanent vindication of every detail of our scientific discoveries, even if they could be pushed to a point which no subsequent investigation in the same difficult line of research would be able to overpass.

Contenting myself with these general remarks, I shall close this chapter with a short summary of the reasons which may be adduced in support of the animal nature of Eozoon, prefaced by an ideal restoration of it in the supposition that it was a rhizopod (Fig. 58). 
In doing so, I shall merely sum up the evidence as it has been presented by Sir W. E. Logan, Dr.

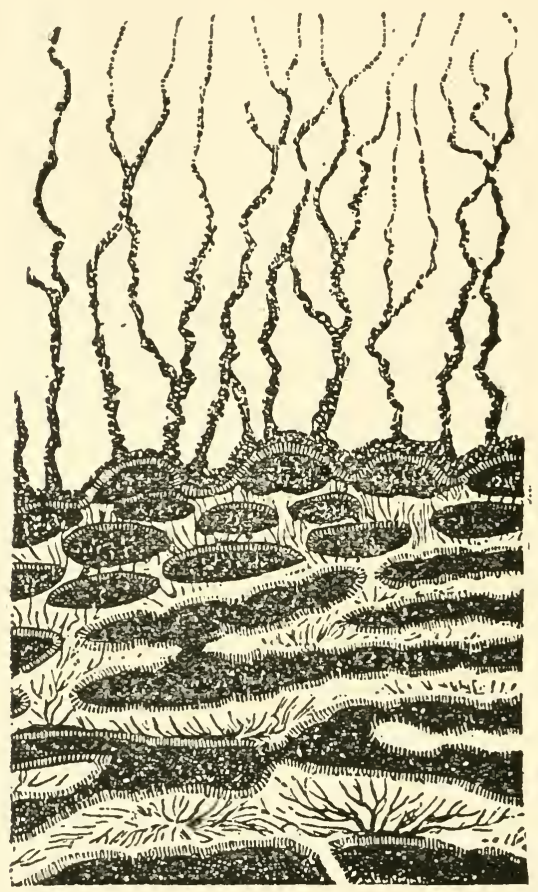

FIG. 58.-Restoration of Eozoon as a generalized Foraminiferal Organism (enlarged).

Showing endosarc, exosarc, and pseudopods, and the calcareous skeleton with its canals.

Carpenter, Dr. Hunt, and the author, in a short and intelligible form; and I shall do so under a few brief heads, with some explanatory remarks:- 
I. The Upper Laurentian of Canada, a rock formation whose distribution, age, and structure have been carefully worked out in several extensive districts by the Canadian Survey, is found to contain thick and widely distributed beds of limestone, related to the other beds in the same way in which limestones occur in the sediments of other geological formations. There also occur in the same formation, graphite, iron ores, and metallic sulphides, in such relations as to suggest the idea that the limestones as well as these other minerals are of organic origin.

2. In the limestones are found laminated bodies of definite form and structure, composed of calcite alternating with serpentine and other minerals. The forms of these bodies suggested a resemblance to the Silurian Stromatoporæ, and the different mineral substances associated with the calcite in the production of similar forms showed that these were not accidental or concretionary.

3. On microscopic examination, it proved that the calcareous laminæe of these forms were similar in structure to the shells of modern and fossil Foraminifera, more especially those of the Rotaline and Nummuline types, and that the finer structures, 
though usually filled with serpentine and other hydrous silicates, were sometimes occupied with calcite, pyroxene, or dolomite, showing that they must when recent have been empty canals and tubes.

4. The mode of filling thus suggested for the chambers and tubes of Eozoon is precisely that which takes place in modern Foraminifera filled with glauconite, and in Palæozoic crinoids and corals filled with other hydrous silicates, all more or less chemically allied to serpentine.

5. The type of growth and structure predicated of Eozoon from the observed appearances, in its great size, its laminated and acervuline forms, and in its canal system and tubulation, are not only in conformity with those of other Foraminifera, but such as might be expected in a very ancient form of that group.

6. Indications exist of other organic bodies in the limestones containing Eozoon, and also of the Eozoon being preserved not only in reefs but in drifted fragmental beds as in the case of modern corals.

7. Similar organic structures have been found in the Laurentian limestones of Massachusetts, New 
York, Brazil, ${ }^{1}$ and also in those of various parts of Europe, and Dr. Gümbel has found an additional species in rocks succeeding the Laurentian.

8. The manner in which the structures of Eozoon are effected by the faulting, development of crystals, mineral veins, and other effects of disturbance and metamorphism in the containing rocks, is precisely that which might be expected on the supposition that it is of organic origin.

9. The exertions of several active and able opponents have failed to show how, otherwise than by organic agency, such structures as those of Eozoon can be formed, except on the supposition of pseudo-morphism and replacement, which must be regarded as chemically extravagant, and which would equally impugn the validity of all fossils determined by microscopic structure. In like manner all comparisons of these structures with dendritic and other imitative forms have signally failed, in the opinion of those best qualified to judge.

Another and perhaps simpler way of putting the case is the following:-Only four general modes of accounting for the existence of Eozoon have been

${ }^{1}$ Fragmental ; specimens from J. A. Derby, Esq. 
proposed. The first is that of Professors King and Rowney, who regard the chambers and canals filled with serpentine as arising from the erosion or partial dissolving away of serpentine and its replacement by calcite. The objections to this are conclusive. It does not explain the fine tubulation, which has to be separately accounted for by confounding it, contrary to the observed facts, with the veins of fibrous serpentine which actually pass through cracks in the fossil. Such replacement is in the highest degree unlikely on chemical grounds, and there is no evidence of it in the numerous serpentine grains, nodules, and bands in the Laurentian limestones. On the other hand, the opposite replacement, that of limestone by serpentine, seems to have occurred. The mechanical difficulties in accounting for the delicate canals on this theory are also insurmountable. Finally, it does not account for the specimens preserved in pyroxene and other silicates, and in dolomite and calcite. A second mode of accounting for the facts is that the Eozoon forms are merely peculiar concretions. But this fails to account for their great difference from the other serpentine concretions in the same beds, and for their regularity of plan and the delicacy of their 
structure, and also for minerals of different kinds entering into their composition, and still presenting precisely the same forms and structures. The third is that first suggested, I think, by Jullien, and later by Gregory and Lavis, that the forms are merely banded alternations of calcite with silicious minerals similar to those observed at the junction of igneous rocks and limestones. To this it may be replied that there is really only an apparent resemblance, which, on careful examination, proves to be illusory; that it does not account for the canals and tubuli, and that studies of such banded rocks from several regions have been made by competent observers, who have distinguished these from the Laurentian Eozoon. The only remaining theory is that of the filling of cavities by infiltration with serpentine. This accords with the fact that such infiltration by minerals akin to serpentine exists in fossils in later rocks. It also accords with the known aqueous origin of the serpentine nodules and bands, the veins of fibrous serpentine, and the other minerals found filling the cavities of Eozoon. Even the pyroxene has been shown by Hunt to exist in the Laurentian in veins of aqueous origin. The only difficulty existing on this view is how a calcite 
skeleton with such chambers, canals, and tubuli could be formed; and this is solved by the discovery that all these facts correspond precisely with those to be found in the shells of modern oceanic Foraminifera. The existence, then, of Eozoon, its structure, and its relations to the containing rocks and minerals being admitted, no rational explanation of its origin seems at present possible other than that advocated in the preceding pages.

If the reader will now turn to the figures in the illustration on the opposite page (Fig. 59), he will find a selection of examples bearing on the above arguments and objections. Fig. I represents a portion of a very thin slice of a specimen traversed by veins of fibrous serpentine or chrysotile, and having the calcite of the walls more broken by cleavage planes than usual. The portion selected shows a part of one of the chambers filled with serpentine, which presents the usual curdled aspect almost impossible to represent in a drawing $(s)$. It is traversed by a branching vein of chrysotile $\left(s^{\prime}\right)$, which, where cut precisely parallel to its fibres, shows clear fine cross lines, indicating the sides of its constituent prisms, and where the plane of section has passed obliquely to its fibres, has a curiously stippled or frowsy ap- 


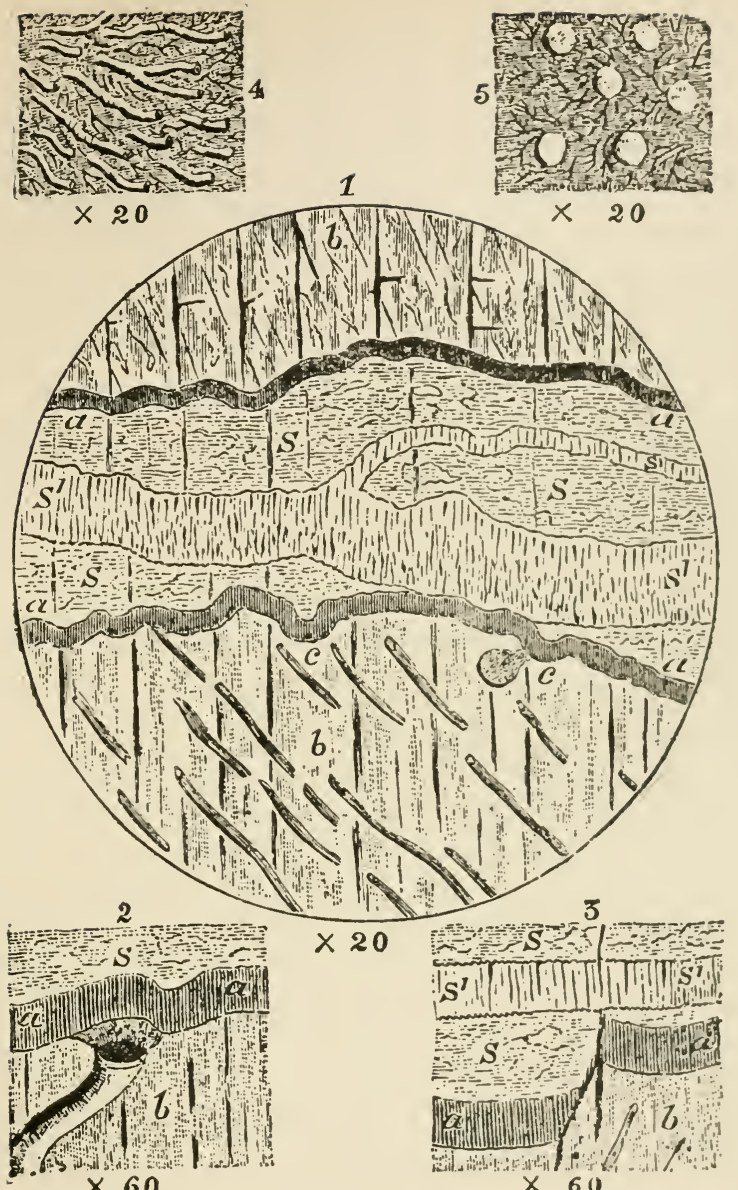

$\times 60$

$\times 60$

FIG. 59. - Figures of various Structures and States of Preservation.

Fig. r.-Portion of two laminæ and intervening serpentine, with chrysotile vein.

(a) Proper wall tubulated. (b) Intermediate skeleton, with liarge canals. (c) Openings of small chamberlets filled with serpentine. (s) Serpentine filling chamber. $\left(s^{1}\right)$ Vein of chrysotile, showing its difference from the proper wall.

Fig. 2. - Junction of a canal and the proper wall. Lettering as in Fig. I.

Fig. 3.--Proper wall shifted by a fault, and more recent chrysotile vein not faulted. Lettering as in Fig. $\mathbf{x}$.

FIG. 4.-Large and small canals filled with dolomite.

Fig. 5.-Abnormally thick portion of intermediate skeleton, with large tubes and small canals filled with dolomite. 

pearance. On either side of the serpentine band is the nummuline or proper wall, showing under a low power a milky appearance, which, with a higher power, becomes resolved into a tissue of the most beautiful parallel threads, representing the filling of its tubuli. Nothing can be more distinct than the appearances presented by this wall and a chrysotile vein, under every variety of magnifying power and illumination; and all who have had an opportunity of examining my specimens have expressed astonishment that appearances so dissimilar should have been confounded with each other. On the lower side two indentations are seen in the proper wall (c). These are connected with the openings into small subordinate chamberlets, one of which is in part included in the thickness of the slice. At the upper and lower parts of the figure are seen portions of the intermediate skeleton traversed by canals, which in the lower part are very large, though from the analogy of other specimens it is probable that they have in their interstices, and at their branching extremities, minute canaliculi not visible in this slice. Fig. 2, from the same specimen, shows the termination of one of the canals against the proper wall, its end expanding into a wide disc 
of sarcode on the surface of the wall, as may be seen in similar structures in modern Foraminifera. In this specimen the canals are beautifully smooth and cylindrical, but they sometimes present a knotted or jointed appearance, especially in specimens decalcified by acids, in which perhaps some erosion has taken place. They are also occasionally fringed with minute crystals, especially in those specimens in which the calcite has been partially replaced with other minerals. Fig. 3 shows an example of faulting of the proper wall, an appearance not infrequently observed; and it also shows a vein of chrysotile crossing the line of fault, and not itself affected by it-a clear evidence of its posterior origin. Figs. 4 and 5 are examples of specimens having the canals filled with dolomite, and showing extremely fine canals in the interstices of the others: an appearance observed only in the thicker parts of the skeleton, and when these are very well preserved. These dolomitized portions require some precautions for their observation, either in slices or decalcified specimens, but when properly managed they show the structures in very great perfection. The specimen in Fig. 5 is from an abnormally thick portion of intermediate skeleton, having unusually 
thick canals, and referred to in a previous chapter. Such additional peculiarities and specialties might be multiplied to any extent from the numerous prepared specimens now in our collections.

One object which I have in view in thus minutely directing attention to these illustrations, is to show the nature of the misapprehensions which may occur in examining specimens of this kind, and at the same time the certainty which may be attained when proper precautions are taken. I may add that such structures as those referred to are best seen in extremely thin slices, and that the observer must not expect that every specimen will exhibit them equally well. It is only by preparing and examining many specimens that the best results can be obtained. It often happens that one specimen is required to show well one part of the structures, and a different one to show another; and previous to actual trial, it is not easy to say which portion of the structures any particular fragment will show most clearly. This renders it somewhat difficult to supply one's friends with specimens. Really good slices can be prepared only from the best material and by skilled manipulators; imperfect slices may only mislead; and rough specimens may not be 
properly prepared by persons unaccustomed to the work, or if so prepared, may not turn out satisfactory, or may not be skilfully examined. One slice heated in the grinding may show nothing but cleavage in the calcite layers, while an adjoining one more carefully prepared may show beautiful canals. These difficulties, however, Eozoon shares with other specimens in micro-geology, and I have experienced similar disappointments in the case of fossil wood.

In conclusion of this part of the subject, and referring to the notes appended to this work for some further details, I would express the hope that those who have hitherto opposed the interpretation of Eozoon as organic, and to whose ability and honesty of purpose I willingly bear testimony, will find themselves enabled to acknowledge at least the reasonable probability of that interpretation of these remarkable forms and structures. 
THE ORIGIN OF LIFE 



\section{$\mathrm{X}$}

\section{THE ORIGIN OF LIFE}

THE thoughts suggested to the philosophical 1 naturalist by the contemplation of the dawn of life on our planet are necessarily many and exciting, and the subject has in it the materials for enabling the general reader better to judge of some of the theories of the origin of life agitated in our time. Let us then put Eozoon into the witness-box, and try to elicit its testimony as to the beginnings of life; supposing for the moment that it is really an animal, and not a mere pretender; though even in that case, it might serve to represent the first animal, whatever it may have been.

Looking down from the elevation of our physiological and mental superiority, it is difficult to realize the exact conditions in which life exists in creatures so simple as the Protozoa. There may perhaps be higher intelligences that find it equally difficult to realize how life and reason can manifest themselves in such poor houses of clay as those we inhabit. But placing ourselves near to these creatures, and entering 
as it were into sympathy with them, we can understand something of their powers and feelings. In the first place, it is plain that they can vigorously, if roughly, exercise those mechanical, chemical, and vegetative powers of life which are characteristic of the animal. They can seize, swallow, digest, and assimilate food; and, employing its albuminous parts in nourishing their tissues, can burn away the rest in processes akin to our respiration, or reject it from their system. Like us, they can subsist only on food which the plant has previously produced; for in this world, from the beginning of time, the plant has been the only organism which could use the solar light and heat as forces to enable it to turn the dead elements of matter into living, growing tissues, and into organic compounds capable of nourishing the animal. Like us, the Protozoa expend the food which they have asssimilated in the production of animal force, and in doing so cause it to be oxidized, or burnt away, and resolved again into dead matter. It is true that we have much more complicated apparatus for performing these functions, but it does not follow that this gives us much real superiority, except relatively to the more difficult conditions of our existence. The gourmand who enjoys his dinner may have no 
more pleasure in the act than the Amøeba which swallows a Diatom; and for all that the man knows of the subsequent processes to which the food is subjected, his interior might be a mass of jelly, with extemporised vacuoles, like that of his humble fellowanimal. The workman or the athlete has bones and muscles of vastly complicated structure, but to him the muscular act is as simple and unconscious a process as the sending out of a pseudopod to a Protozoon. The clay is after all the same, and there may be as much credit to the artist in making a simple organism with varied powers, as a more complex frame for doing nicer work. It is a weakness of humanity to plume itself on advantages not of its own making, and to treat its superior gifts as if they were the result of its own endeavours. The truculent traveller who illustrated his boast of superiority over the Indian by comparing his rifle with the bow and arrows of the savage, was well answered by the question, "Can you make a rifle?" and when he had to answer, "No," by the rejoinder, "Then I am at least better than you, for I can make my bow and arrows." The Amœba or the Eozoon is probably no more than we its own creator; but if it could produce itself out of vegetable matter, or out of inorganic 
substances, it might claim in so far a higher place in the scale of being than we ; and as it is, it can assert equal powers of digestion, assimilation, and motion, with much less of bodily mechanism.

In order that we may feel, a complicated apparatus of nerves and brain-cells has to be constructed and set to work; but the Protozoon, without any distinct brain, is all brain, and its sensation is simply direct. Thus vision in these creatures is probably performed in a rough way by any part of their transparent bodies, and taste and smell are no doubt in the same case. Whether they have any perception of sound as distinct from the mere vibrations ascertained by touch, we do not know. Here also we are not far removed above the Protozoa, especially those of us to whom touch, seeing, and hearing are mere feelings, without thought or knowledge of the apparatus employed. We might so far as well be Amœbas. As we rise higher we meet with more differences. Yet it is evident that our gelatinous fellow-being can feel pain, dread danger, desire possessions, enjoy pleasure, and in a simple, unconscious way entertain many of the appetites and passions that affect ourselves. The wonder is that with so little of organization it can do so much. Yet, perhaps, life can manifest itself in a 
broader and more intense way where there is little organization; and a highly strung and complex organism is not so much a necessary condition of a higher life as a mere means of better adapting it to its present surroundings. Those philosophies which identify the thinking mind with the material organism, must seem outrageous blunders to an Amceba on the one hand, or to an angel on the other, could either be enabled to understand them; which, however, is not very probable, as they are too intimately bound up with the mere prejudices incident to the present condition of our humanity. In any case, the Protozoa teach us how much of animal function may be fulfilled by a very simple organism, and warn us against the fallacy that creatures of this simple structure are necessarily nearer to inorganic matter, and more easily developed from it than beings of more complex mould.

A similar lesson is taught by the complexity of their skeletons. We speak in a crude, unscientific way of these animals accumulating calcareous matter, and building up reefs of limestone. We must, however, bear in mind that they are as dependent on their food for the materials of their skeletons as we are, and that their crusts grow in the interior of the 
sarcode just as our bones do within our bodies. The provision even for nourishing the interior of the skeleton by tubuli and canals is in principle similar to that involved in the Haversian canals, cells, and canalicules of bone. The Protozoon of course knows neither more nor less of this than the average Englishman. It is altogether a matter of unconscious growth. The process in the Protozoa strikes some minds, however, as the more wonderful of the two. It is, says an eminent modern physiologist, a matter of "profound significance" that this "particle of jelly [the sarcode of a Foraminifer] is capable of guiding physical forces in such a manner as to give rise to these exquisite and almost mathematically arranged structures." Respecting the structures themselves, there is no exaggeration in this. No arch or dome framed by human skill is more perfect in beauty or in the realization of mechanical ideas than the tests of some Foraminifera, and none is so complete and wonderful in its internal structure. The particle of jelly, however, is a figure of speech. The body of the humblest Foraminifer is much more than this. It is an organism with divers parts, as we have already seen in a previous chapter, and it is endowed with the mysterious forces of life which 
in it guide the physical forces, just as they do in building up phosphate of lime in our bones, or indeed just as the will of the architect does in building a palace. The profound significance which this has, reaches beyond the domain of the physical and vital, even to the spiritual. It clings to all our conceptions of living things: quite as much, for example, to the evolution of an animal, with all its parts from a one-celled germ, or to the connection of brain-cells with the manifestations of intelligence. Viewed in this way, we may share with the author of the sentence I have quoted his feeling of veneration in the presence of this great wonder of animal life, "burning, and not consumed," nay, building up, and that in many and beautiful forms. We may realize it most of all in the presence of the organism which was perhaps the first to manifest on our planet these marvellous powers. We must, however, here, also, beware of that credulity which makes too many thinkers limit their conceptions altogether to physical force in matters of this kind. The merely materialistic physiologist is really in no better position than the savage who. quails before the thunderstorm, or rejoices in the solar warmth, and seeing no force or power beyond, fancies himself in the immediate 
presence of his God. In Eozoon we must discern not only a mass of jelly, but a being endowed with that higher vital force which surpasses vegetable life and also physical and chemical forces; and in this animal energy we must see an emanation from a Will higher than our own, ruling vitality itself; and this not merely to the end of constructing the skeleton of a Protozoon, but of elaborating all the wonderful developments of life that were to follow in succeeding ages, and with reference to which the production and growth of this creature were initial steps. It is this mystery of design which really constitutes the "profound significance" of the foraminiferal skeleton.

Another phenomenon of animality forced upon our notice by the Protozoa is that of the conditions of life in animals not indiviclual, as we are, but aggregative and accumulative in indefinite masses. What, for instance, the relations to each other of the Polyps, growing together in a coral mass, of the separate parts of a Sponge, or the separate cells of a Foraminifer, or of the sarcode mass of an indefinitely spread out Cryptozoon. In the case of the Polyps, we may believe that there is special sensation in the tentacles and oral opening of each 
individual, and that each may experience hunger when in want, or satisfaction when it is filled with food, and that injuries to one part of the mass may indirectly affect other parts, but that the nutrition of the whole mass may be as much unfelt by the individual Polyps as the processes going on in our own bones are by us. So in the case of a large Sponge or Foraminifer, there may be some special sensation in individual cells, pseudopods, or segments, and the general sensation may be very limited, while unconscious living powers pervade the whole. In this matter of aggregation of animals we have thus various grades. The Foraminifers and Sponges present us with the simplest of all, and that which most resembles the aggregation of buds in the plant. The Polyps and complex Bryozoons present a higher and more specialized type; and though the bilateral symmetry which obtains in the higher animals is of a different nature, it still at least reminds us of that multiplication of similar parts which we see in the lower grades of being. It is worthy of notice here that the lower animals which show aggregative tendencies present but imperfect indications, or none at all, of bilateral symmetry. Their bodies, like 
those of plants, are for the most part built up around a central axis, or they show tendencies to spiral modes of growth.

It is this composite sort of life which is connected with the main geological function of the Foraminifer. While active sensation, appetite, and enjoyment pervade the pseudopods and external sarcode of the mass, the hard skeleton common to the whole is growing within; and in this way the calcareous matter is gradually removed from the sea-water, and built up in solid reefs, or in piles of loose foraminiferal shells. Thus it is the aggregative or common life, alike in Foraminifers as in Corals, that tends most powerfully to the accumulation of calcareous matter; and those creatures whose life is of this complex character are best suited to be world-builders, since the result of their growth is not merely a cemetery of their osseous remains, but a huge communistic edifice, to which multitudes of lives have contributed, and in which successive generations take up their abode on the remains of their ancestors. This process, so potent in the progress of the earth's geological history, began, as far as we know, with Eozoon.

Whether, then, in questioning our proto-fora- 
minifer, we have reference to the vital functions of its gelatinous sarcode, to the complexity and beauty of its calcareous test, or to its capacity for effecting great material results through the union of individuals, we perceive that we have to do, not with a low condition of those powers which we designate life, but with the manifestation of those powers through the means of a simple organism; and this in a degree of perfection which we, from our point of view, would have in the first instance supposed impossible.

If we imagine a world altogether destitute of life, we still might have geological formations in progress. Not only would volcanoes belch forth their liquid lavas and their stones and ashes, but the waves and currents of the ocean and the rains and streams on the land, with the ceaseless decomposing action of the carbonic acid of the atmosphere, would be piling up mud, sand, and pebbles in the sea. There might even be some formation of limestone taking place where springs charged with bicarbonate of lime were oozing out on the land or the bottom of the waters. But in such a world all the carbon would be in the state of carbonic acid, and all the limestone would either be diffused 
in small quantities through various rocks or in limited local beds, or in solution, perhaps as chloride of calcium, in the sea. Dr. Hunt has given chemical grounds for supposing that the most ancient seas were largely supplied with this very soluble salt, instead of the chloride of sodium, or common salt, which now prevails in the sea-water.

Where in such a world would life be introduced? on the land or in the waters? All scientific probability would say in the latter. (The ocean is now vastly more populous than the land.) The waters alone afford the conditions necessary at once for the most minute and the grandest organisms, at once for the simplest and for others of the most complex character. Especially do they afford the best conditions for those animals which subsist in complex communities, and which aggregate large quantities of mineral matter in their skeletons. So true is this that up to the present time all the species of Protozoa and of the animals most nearly allied to them are aquatic. Even in the waters, however, plant life, though possibly in very simple forms, must precede the animal.

Let humble plants, then, be introduced in the waters, and they would at once begin to use the 
solar light for the purpose of decomposing carbonic acid, and forming carbon compounds which had not before existed, and which independently of vegetable life would never have existed. At the same time lime and other mineral substances present in the sea-water would be fixed in the tissues of these plants, either in a minute state of division, as little grains or Coccoliths, or in more solid masses like those of the Corallines and Nullipores. In this way a beginning of limestone formation might be made, and quantities of carbonaceous and bituminous matter, resulting from the decay of marine plants, might accumulate in the sea-bottom. The plants have collected stores of organic matter, and their minute germs, along with microscopic species, are floating everywhere in the sea. Nay, there may be abundant examples of those Amcebalike germs of aquatic plants, simulating for a time the life of the animal, and then returning into the circle of vegetable life. In these some might see precursors of the Protozoa, though they are probably rather prophetic analogues than blood relations. The plant has fulfilled its function as far as the waters are concerned, and now arises the opportunity for the animal. In what form shall 
it appear? Many of its higher forms, those which depend upon animal food or on the more complex plants for subsistence, would obviously be unsuitable. Further, the sea-water is still too much saturated with saline matter to be fit for the higher animals of the waters. Still further, there may be a residue of internal heat forbidding coolness, and that solution of free oxygen which is an essential condition of existence to most of the modern animals. ${ }^{1}$ Something must be found suitable for this saline, imperfectly oxygenated, tepid sea. Something too is wanted that can aid in introducing conditions more favourable to higher life in the future. Our experience of the modern world shows us that all these conditions can be better fulfilled by the Protozoa than by any other creatures. They can live now equally in those great depths of ocean where the conditions are most unfavourable to other forms of life, and in tepid unhealthy pools overstocked with vegetable matter in a state of putridity. They form a most suitable basis for

${ }^{1}$ It has been assumed that any temperature over $120^{\circ}$ Fahrenheit would be incompatible with ordinary aquatic life. Stitl such life is at least possible in some form up to $200^{\circ}$. 
higher forms of life. They have remarkable powers of removing mineral matters from the waters and of fixing them in solid forms. So in the fitness of things Eozoon is just what we need, and after it has spread itself over the mud and rock of the primeval seas, and built up extensive reefs therein, other animals may be introduced capable of feeding on it, or of sheltering themselves in its stony masses, and thus we have the appropriate dawn of animal life.

But what are we to say of the cause of this new series of facts, so wonderfully superimposed upon the merely vegetable and mineral? Must it remain to us as an act of creation, or was it derived from some pre-existing matter in which it had been potentially present? Science fails to inform us, but conjectural "phylogeny" steps in and takes its place. Haeckel, one of the prophets of this new philosophy, waves his magic wand, and simple masses of sarcode spring from inorganic matter, and form diffused sheets of sea-slime, from which are in time separated distinct Amœboid and Foraminiferal forms. Experience, however, gives us no facts whereon to build this supposition, and it remains neither more nor less scientific or certain 
than that old fancy of the Egyptians, which derived animals from the fertile mud of the Nile.

If we fail to learn anything of the origin of Eozoon, and if its life-processes are just as inscrutable as those of higher creatures, we can at least inquire as to its history in geological time. In this respect we find in the first place that the Protozoa have not had a monopoly in their profession of accumulators of calcareous rock. Originated by Eozoon in the old Laurentian time, this process has been proceeding throughout the geological ages; and while Protozoa, equally simple with the great prototype of the race, have been and are continuing its function, and producing new limestones in every geological period, and so adding to the volume of the successive formations, new workers of higher grades have been introduced, capable of enjoying higher forms of animal activity, and equally of labouring at the great task of continent-building; of existing, too, in seas less rich in mineral substances than those of the Eozoic time, and for that very reason better suited to higher and more skilled artists. It is to be observed in connection with this, that as the work of the Foraminifers has thus been assumed by 
others, their size and importance have diminished, and the grander forms of more recent times have some of them been fain to build up their hard parts of cemented sand instead of limestone.

But we further find that, while the first though not the only organic gatherers of limestone from the ocean waters, they have had to do, not merely with the formation of calcareous sediments, but also with that of silicious deposits. The greenish silicate called glauconite, or greensand, is found to be associated with much of the foraminiferal slime now accumulating in the ocean, and also with the older deposits of this kind now consolidated in chalks and similar rocks. This name glauconite is, as Dr. Hunt has shown, employed to designate not only the hydrous silicate of iron and potash, which perhaps has the best right to it, but also compounds which contain in addition large percentages of alumina, or magnesia, or both; and one glauconite from the Tertiary limestones near Paris is said to be a true serpentine, or hydrous silicate of magnesia. ${ }^{1}$ Now the association of such substances with Foraminifera is not purely accidental. Just as a fragment of

1 Berthier, quoted by Hunt. 
decaying wood, imbedded in sediment, has the power of decomposing soluble silicates carried to it by water, and parting with its carbon in the form of carbonic acid, in exchange for the silica, and thus replacing, particle by particle, the carbon of the wood with silicon, so that at length it becomes petrified into a flinty mass, so the sarcode of a Foraminifer can in like manner abstract silica from the surrounding water or water-soaked sediment. From some peculiarity in the conditions of the case, however, our Protozoon usually becomes petrified with a hydrous silicate instead of with pure silica. The favourable conditions presented by the deep sea for the combination of silica with bases, as indicated in the reports of the Challenger already referred to, may perhaps account in part for this. But whatever the cause, it is usual to find fossil Foraminifera with their sarcode replaced by such material. We also find beds of glauconite retaining the forms of Foraminifera, while the calcareous tests of these have been removed, apparently by acid waters.

One consideration which, though conjectural, deserves notice, is connected with the food of these humble animals. They are known to feed to a large extent on minute plants, the Diatoms, and other 
organisms having silica in their skeletons or cellwalls, and consequently soluble silicates in their juices. The silicious matter contained in these organisms is not wanted by the Foraminifera for their own skeletons, and will therefore be voided by them as an excrementitious matter. In this way, where Foraminifera greatly abound, there may be a large production of soluble silica and silicates, in a condition ready to enter into new and insoluble compounds, and to fill the cavities and pores of dead shells. Thus glauconite and even serpentine may, in a certain sense, be a sort of foraminiferal coprolitic matter or excrement. Of course it is not necessary to suppose that this is the only source of such materials. They may be formed in other ways, and especially by the disintegration of volcanic ashes and lapilli in the sea-bottom; but I suggest this as at least a possible link of connection.

Whether or not the conjecture last mentioned has any validity, there is another and most curious bond of connection between oceanic Protozoa and silicious deposits. Professor Wyville Thompson reports from the Challenger soundings, that in certain areas of the South Pacific the ordinary foraminiferal ooze is replaced by a peculiar red clay, which he attributes to 
the action of water laden with carbonic acid, in removing all the lime, and leaving this red mud as a sort of ash, composed of silica, alumina, and iron oxide. Now this is in all probability a product of the decomposition and oxidation of the glauconitic matter contained in the ooze. Thus we learn that when areas on which calcareous deposits have been accumulated by Protozoa are invaded by cold arctic or antarctic waters charged with carbonic acid, the carbonate of lime may be removed, and the glauconite left, or even the latter may be decomposed, leaving silicious, aluminous, and other deposits, which may be quite destitute of any organic structures, or retain only such remnants of them as have been accidentally or by their more resisting character protected from destruction. ${ }^{1}$ In this way it may be

1 The "red chalk" of Antrim, and that of Speeton, contain arenaceous Foraminifera and silicious casts of their shells, apparently different from typical glauconite, and the extremely fine ferruginous and argillaceous sediment of these chalks may well be decomposed glauconitic matter like that of the South Pacific. I have found these beds, the hard limestones of the French Neocomian, and the altered greensands of the Alps, very instructive for comparison with the Laurentian limestones; and they well deserve study by all interested in such subjects. 
possible that many silicious rocks of the Laurentian and Primordial ages, which now show no trace of organization, may be indirectly products of the action of life. In any case it seems plain that beds of greensand and similar hydrous silicates may be the residue of thick deposits of foraminiferal limestone or chalky matter, and that these silicates may in their turn be oxidized and decomposed, leaving beds of apparently inorganic clay. Such beds may finally be consolidated and rendered crystalline by metamorphism, and thus a great variety of silicated rocks may result, retaining little or no indication of any connection with the agency of life. We can scarcely yet conjecture the amount of light which these new facts may eventually throw on the serpentine and other rocks of the Eozoic age. In the meantime they open up a noble field to chemists and microscopists.

When the marvellous results of recent deep-sea dredgings were first made known, and it was found that chalky foraminiferal earth is yet accumulating in the Atlantic, with sponges and sea-urchins resembling in many respects those whose remains exist in the chalk, the fact was expressed by the statement that we still live in the chalk period. 
Thus stated, the conclusion is scarcely correct. We do not live in the chalk period, but the conditions of the chalk period still exist in the deep sea. We may say more than this. To some extent the conditions of the Laurentian period still exist in the sea, except in so far as they have been removed by the action of the Foraminifera and other limestone builders. To those who can realize the enormous lapse of time involved in the geological history of the earth, this conveys an impression almost of eternity in the existence of this oldest of all the families of the animal kingdom.

We are still more deeply impressed with this when we bring into view the great physical changes which have occurred since the dawn of life. When we consider that the skeletons of Eozoon contribute to form the oldest hills of our continents; that they have been sealed up in solid marble, and that they are associated with hard crystalline rocks contorted in the most fantastic manner; that these rocks have, almost from the beginning of geological time, been undergoing waste to supply the material of new formations; that they have witnessed innumerable subsidences and elevations of the continents; and that the greatest mountain chains of the earth have 
been built up from the sea since Eozoon began to exist,-we acquire a most profound impression of the persistence of the lower forms of animal life, and know that mountains may be removed and continents swept away and replaced, before the least of the humble gelatinous Protozoa can finally perish. Life may be a fleeting thing in the individual, but as handed down through successive generations of beings, and as a constant animating power in successive organisms, it appears, like its Creator, eternal.

This leads to another and very serious question. How long did lineal descendants of Eozoon exist, and do they still exist? We may for the present consider this question apart from ideas of derivation and elevation into higher planes of existence of which, in point of fact, we have no actual evidence. Eozoon as a species and even as a genus may cease to exist with the Eozoic age, and we have no proof that any succeeding forms of Pr tozoa are its modified descendants. Whatever the causes which produced the earliest Protozoan, they may have continued more or less to be operative in succeeding ages. As far as their structures inform us, they may as much claim to be original creations as Eozoon itself. Still 
descendants of Eozoon may have continued to exist, though we have not yet met with them. I should not be surprised to hear of a veritable specimen being some day dredged alive in the Atlantic or the Pacific. It is also to be observed that in animals so simple as Eozoon many varieties may appear, widely different from the original. In these the general form and habit of life are the most likely things to change, the minute structures much less so. We need not, therefore, be surprised to find its descendants diminishing in size or altering in general form, while the characters of the fine tubulation and of the canal system would remain. We need not wonder if any sessile Foraminifer of the Nummuline group should prove to be a descendant of Eozoon. It would be less likely that a Sponge or a Foraminifer of the Rotaline type should originate from it. If one could only secure a succession of deep-sea limestones with Foraminifers, extending all the way from the Laurentian to the present time, I can imagine nothing more interesting than to compare the whole series, with the view of ascertaining the limits of descent with variation, and the points where new forms are introduced. We have not yet such a series, but it may be obtained; and as Foraminifera 
are eminently cosmopolitan, occurring over vastly wide areas of sea-bottom, and are very variable, they would afford a better test of theories of derivation than any that can be obtained from the more locally distributed and less variable animals of higher grade. I was much struck with this recently, in examining a series of Foraminifera from the Cretaceous of Manitoba, and comparing them with the varietal forms of the same species in the interior of Nebraska, 500 miles to the south, and with those of the English chalk and or the modern seas. In all these different times and places we had the same species. In all they existed under so many varietal forms passing into each other, that in former times every species had been multiplied into several. Yet in all, the identical varietal forms were repeated with the most minute markings alike. Here were at once constancy the most remarkable and variations the most extensive. If we dwell on the one to the exclusion of the other, we reach only one-sided conclusions, imperfect and unsatisfactory. By taking both in connection we can alone realize the full significance of the facts. We cannot yet obtain such series for all geological time; but it may even now be worth while to inquire, What do we know as to any modification 
in the case of the primeval Foraminifers, whether with reference to the derivation from them of other Protozoa or of higher forms of life?

There is no link whatever in geological fact to connect Eozoon with any of the Mollusks, Radiates, or Crustaceans of the succeeding Palæozoic. What may be discovered in the future we cannot conjecture; ( but at present these stand before us as distinct creations. It would, of course, be more probable that Eozoon should be the ancestor of some of the Foraminifera of the Primordial age, but strangely enough it is very dissimilar from all these except Cryptozoon; and here, as already stated, the evidence of minute structure fails to a great extent, and Eozoon Bavaricum of the Huronian age scarcely helps to bridge over the gap which yawns in our imperfect geological record. Of actual facts, therefore, we have none; and those evolutionists who have regarded the dawn-animal as an evidence in their favour, have been obliged to have recourse to supposition and assumption.

Taking the ground of the derivationist, it is convenient to assume (I) that Eozoon was either the first or nearly the first of animals, and that, being a Protozoan of simple structure, it constitutes an appro- 
priate beginning of life; (2) that it originated from some unexplained change in the protoplasmic or albuminous matter of some humble plant, or directly from inorganic matter, or at least was descended from some creature only a little more simple which had being in this way; (3) that it had in itself unlimited capacities for variation and also for extension in time; (4) that it tended to multiply rapidly, and at last so to occupy the ocean that a struggle for existence arose; (5) that though at first, from the very nature of its origin, adapted to the conditions of the world, yet as these conditions became altered by physical changes, it was induced to accommodate itself to them, and so to pass into new species and genera, until at last it appeared in entirely new types in the Cambrian fauna.

These assumptions are, with the exception of the first two, merely the application to Eozoon of what have been called the Darwinian laws of multiplication, of limited population, of variation, of change of physical conditions, and of equilibrium of nature. If otherwise proved, and shown to be applicable to creatures like Eozoon, of course we must apply them to it; but in so far as that creature itself is concerned they are incapable of proof, and some of 
them contrary to such evidence as we have. We have, for example, no connecting link between Eozoon and any form of vegetable life. Its structures are such as to enable us at once to assign it to the animal kingdom, and if we seek for connecting links between the lower animals and plants, we have to look for them in the modern waters. We have no reason to conclude that Eozoon could multiply so rapidly as to fill all the stations suitable for it, and to commence a struggle for existence. On the contrary, after the lapse of untold ages the conditions for the life of Foraminifers still exist over two-thirds of the surface of the earth. In regard to variation, we have, it is true, evidence of the wide range of varieties of species in Protozoa, within the limits of the group, but none whatever of any tendency to pass into other groups. Nor can it be proved that the conditions of the ocean were so different in Cambrian or Silurian times as to preclude the continued and comfortable existence of Eozoon. New creatures came in which superseded it, and new conditions more favourable in proportion to these new creatures; but neither the new creatures nor the new conditions were necessarily or probably connected with Eozoon, any farther than that it may 
have served newer tribes of animals for food, and may have rid the sea of some of its superfluous lime in their interest. In short, the hypothesis of evolution will explain the derivation of other animals from Eozoon if we adopt its assumptions, just as it will in that case explain anything else; but the assumptions are improbable, and contrary to such facts as we know.

Eozoon itself, however, bears some negative though damaging testimony against evolution, and I take the liberty of repeating here a summary of its imaginary autobiography :- “ I, Eozoon Canadense, being a creature of low organization and intelligence, and of practical turn, am no theorist, but have a lively appreciation of such facts as I am able to perceive. I found myself growing upon the seabottom, and know not whence I came. I grew and flourished for ages, and found no let or hindrance to my expansion, and abundance of food was always floated to me without my having to go in search of it. At length a change came. Certain creatures with hard snouts and jaws began to prey on me. Whence they came I know not; I cannot think that they came from the germs which I had dispersed so abundantly throughout the ocean. Un- 
fortunately, just at the same time lime became a little less abundant in the waters, perhaps because of the great demands I myself had made, and thus it was not so easy as before to produce a thick supplemental skeleton for defence. So I had to give way. I have done my best to avoid extinction; but it is clear that I must at length be overcome, and must either disappear or subside into a humbler condition, and that other creatures better provided for the new conditions of the world must take my place." In such terms we may suppose that this patriarch of the seas might tell his history, and mourn his destiny, though he might also congratulate himself on having in an honest way done his duty and fulfilled his function in the world, leaving it to other and perhaps wiser creatures to dispute as to his origin and fate, while much less perfectly fulfilling the ends of their own existence.

Thus our dawn-animal has positively no story to tell as to his own introduction or his transmutation into other forms of existence. He leaves the mystery of creation where it was; but in connection with the subsequent history of life we can learn from him a little as to the laws which have governed the succession of animals in geological time. First, 
we may learn that the plan of creation has been progressive, that there has been an advance from the few, low, and generalized types of the primæval ocean to the more numerous, higher, and more specialized types of more recent times. Secondly, we learn that the lower types, when first introduced, and before they were subordinated to higher forms of life, existed in some of their grandest modifications as to form and complexity, and occupied very important places in the economy of the world, and that in succeeding ages, when higher types were replacing them they were subjected to decay and degeneracy. Thirdly, we learn that while the species has a limited term of existence in geological time, any grand type of animal existence, like that of the Foraminifera or of the Sponges, once introduced, continues and finds throughout all the vicissitudes of the earth some appropriate residence. Fourthly, as to the mode of introduction of new types, or whether such creatures as Eozoon had any direct connection with the subsequent introduction of mollusks, worms, or crustaceans, it is altogether silent, nor can it predict anything as to the order or manner of their introduction.

Had we been permitted to visit the Laurentian 
seas, and to study Eozoon and its contemporary Protozoa when alive, it is plain that we could not have foreseen or predicted from the consideration of such organisms the future development of life. No amount of study of the prototypal Foraminifer could have led us distinctly to the conception of even a Sponge or a Polyp, much less of any of the higher animals. Why is this? The answer is that the improvement into such higher types does not take place by any change of the elementary sarcode, either in those chemical, mechanical, or vital properties which we can study, but in the adding to it of new structures. In the Sponge, which is perhaps the nearest type of all, we have the movable pulsating cilium and true animal cellular tissue, and along with this the spicular or fibrous skeleton, these structures leading to an entire change in the mode of life and subsistence. In the higher types of animals it is the same. Even in the highest we have white blood-corpuscles and germinal matter, which, in so far as we know, carry on no higher functions of life than those of an Amoba; but they are now made subordinate to other kinds of tissue, of great variety and complexity, which never have been observed to arise 
out of the growth of any Protozoon. There would be only a very few conceivable inferences which the highest finite intelligence could deduce as to the development of future and higher animals. $\mathrm{He}$ might infer that the foraminiferal sarcode, once introduced, might be the substratum or foundation of other but unknown tissues in the higher animals, and that the Protozoan type might continue to subsist side by side with higher forms of living things as they were successively introduced. $\mathrm{He}$ might also infer that the elevation of the animal kingdom would take place with reference to those new properties of sensation and voluntary motion in which the humblest animals diverge from the life of the plant.

It is important that these points should be clearly before our minds, because there has been current of late among naturalists a loose way of writing with reference to them, which seems to have imposed on many who are not naturalists. It has been said, for example, that such an organism as Eozoon may include potentially all the structures and functions of the higher animals, and that it is possible that we might be able to infer or calculate all these with as much certainty as we can calculate an 
eclipse or any other physical phenomenon. Now, there is not only no foundation in fact for these assertions, but it is from our present standpoint not conceivable that they can ever be realized. The laws of inorganic matter give no data whence any a priori deductions or calculations could be made as to the structure and vital forces of the plant. The plant gives no data from which we can calculate the functions of the animal. The Protozoon gives no data from which we can calculate the specialties of the Mollusc, the Articulate, or the Vertebrate. Nor unhappily do the present conditions of life of themselves give us any sure grounds for predicting the new creations that may be in store for our old planet. Those who think to build a philosophy and even a religion on such data are mere dreamers, and have no scientific basis for their dogmas. They are more blind guides than our primæval Protozoon himself would be, in matters whose real solution lies in the harmony of our own higher and immaterial nature with the Being who is the author of all life-the Father "from whom every family in heaven and earth is named," 
SOME GENERAL CONCLUSIONS

279 



\section{XI}

SOME GENERAL CONCLUSIONS

$\mathrm{T}^{\mathrm{T}}$ may very properly be said that many elements 1 of uncertainty accompany the questions discussed in the previous chapters, and that in any case our information is too scanty to warrant any positive conclusions respecting the origin and earliest history of living beings. On the other hand, it is well to take stock of what we do know, and even of what we may reasonably suppose; keeping always in view the fact that some parts of the problem of the origin of life are at present insoluble, and may possibly ever continue in that condition. I may, therefore, profitably close with a summary of what at present seem to be ultimate facts and principles in this matter, which, if we have not yet fully attained to, we may at least keep in view as objective points.

If we admit that Eozoon was an animal, we may either assume that it was the first introduced on the earth, or that there were earlier and possibly even simpler creatures. In either case we begin 
the chain of animal life with a Protozooan belonging to one of the simpler or more generalized types of that group, and entitled to the name, both because of its place in order of time and of rank in the development of the animal kingdom. If we deny the claims of Eozoon, then the base of our animal system must for the present be found in the Sponges, Worms, Foraminifera, and Radiolarians of the Huronian, with the problematical laminated forms allied to Cryptozoon which seem to occur even in the Upper Laurentian. Thus in this case the miracle of creation stands before us in a somewhat more complex form, though greatly less so than if we had to accept the fauna of the Lower Cambrian as the oldest known.

Under any supposition we cannot hope to get beyond a Protozoan or a few Protozoa, and we must assume that these could perform perfectly in their simple way those functions of assimilation, organic growth, reproduction, sensation, and spontaneous motion, which are characteristic of these lowest forms of life in the present world.

It is plain, finally, that however simple we imagine this first possessor of animal life to be, we can have no scientific evidence of its origination either as 
an embryo or as an adult. If it had no living ancestors, we are thus face to face with the problem of the origin of animal life, either by what has been termed "Abiogenesis" of a merely physical and fortuitous kind, or by creation. This implies the previous production of the complex organic compound known as "Protoplasm," which can, so far as we know, be produced only through the agency of previously living "Protoplasm" formed by living plants. We have, therefore, to presuppose the "Abiogenesis" or creation of plants as predecessors of the animal; but here the same difficulty meets us. We have next to imagine the spontaneous origin of the structures of the "Protozoon" - its outer and inner substance, its nucleus, its pulsating vesicle, and its pseudopods, with its protective test, and its endowment with vital powers of locomotion, sensation, assimilation, nutrition, and reproduction. Can we suppose that all this could come of the chance interaction of physical causes?

At present the production of the living from the non-living seems to be an impossibility, and the suggestion that at some vastly distant point of past time physical conditions may have been so 
different from those at present existing as to permit spontaneous generation is of no scientific value. But if the existence of one primitive Protozoon be granted, what reason have we to believe that it contains potentially the germ of all the succeeding creatures in the great chain of life, and the power of co-ordinating these with the successive physical changes of the geological ages, and so producing the vast and complicated system of the animal kingdom, extending up to the present time? In doing so, we either elevate a low form of animal life into the role of Creator, or fall back on indefinite chance, with infinite probabilities against us. Reason, in short, requires us to believe in a First Cause, self-existent, omnipotent and all-wise, designing from the first a great and homogeneous plan, of which as yet but little has been discovered by us. Thus any rational scheme of development of the earth's population in geological time must be, not an agnostic evolution, but a reverent inquiry into the mode by which it pleased the Creator to proceed in His great work.

Regarding the matter in this way, there is legitimate scope for science in tracing the long lines of the different types of ancient animals to the 
modern period, and endeavouring to discover which of our so-called species are original types and which are mere derivative varieties or races.

It is evident that nothing is gained here by assuming that the whole geological record is but one of innumerable vast æons of æons, which have gone on in endless succession. If the world is made to stand on an elephant, and this on a tortoise, and this on lower forms, it helps us not at all if the last supporter must stand on nothing. The difficulty thus postponed only becomes greater; and at the end we have to imagine, not only life and organization, but even matter and energy as fortuitously originating or creating themselves, unless produced by an Almighty Eternai Will.

In pursuing studies of this kind, it is best for the present to content ourselves with tracing the continuous chains of similar creatures throughout their extension in geological time, rather than to seek for connecting links between different lines of being. I endeavoured some years ago to give a popular outline of this method in a little work entitled "The Chain of Life in Geological Time." 1

${ }^{1}$ Religious Tract Society, London; Revell Publishing Co., New York, Chicago, and Toronto. 
Taking, for example, the earliest Protozoa-the Foraminifera and Radiolaria - we find two lines of being that in endless varieties, but with little material change, extend from the earliest periods to the present time. In successive ages they are represented by families, genera, and species, which are regarded as distinct, and known by different names. But these humble animals are very variable, and what seem to us to be new types may be merely varieties of ancestral forms. We might even affirm that, for all we know, these two great groups, as they exist in the present ocean, are lineal descendants of those that flourished in the Eozoic. We could not prove this, unless we were to find somewhere a continuous succession of deep-sea deposits that would show the gradual changes that had occurred. On the other hand, it is hard to believe that one individual life, so to speak, could have continued unimpaired to animate successive and increasing masses of matter in all the vast time extending from the Eozoic to the modern. It is also at least equally possible that the causes and conditions, whatever they were, that produced the earliest Protozoa may have acted again and again in later times, originating new lines of descent with renewed vitality. 
Still, the tracing of these almost incredibly long lines of descent, if they are such, is a proper, though difficult, subject of scientific research, whatever may be the result. Something has been attempted in this direction over limited portions of time; but a vast amount of patient labour is required before certainty can be attained even in this department of investigation.

When, on the other hand, we turn to the question whether such lines of creation or descent have given off branches leading to new types, as, for instance, from Protozoa to various Crustaceans or Mollusks, we are entirely destitute of facts, and the statement lately made by a leading agnostic evolutionist, that "if there is any truth in the doctrine of evolution, every class of the animal kingdom must be vastly older than the past records of its appearance on the surface of the globe," shows us that all the attempts to construct genealogical trees of the descent of animals are, so far as at present known, quite visionary. It seems, indeed, that each leading line, as we trace it back, ends in a blind alley, just where we might suppose that it was about to pass into another path. This is one reason of the frequent complaints as to the imper- 
fection of the geological record, and of the occurrence of "missing links" between different types of being. The only feasible explanations of this are as yet the suppositions that the times of introduction of new types may have been unfavourable to the preservation of their remains, or that the first representatives of each new group were soft-bodied animals incapable of preservation, or that they happened to be introduced in regions yet unexplored. But such accidents could scarcely have been the rule in every case. Even in relation to man himself, he is still man in all the deposits in which we can find his remains, and as remote from the apes of his time, in so far as we know, as he is from those now his contemporaries. It would seem, in short, as if, ashamed of his humble origin, he had carefully obliterated his tracks in ascending from his lowly parentage to the dignity of humanity. But in this he is only following the example of other animals, his predecessors. We may, as is now constantly done by evolutionists, fill up these gaps by plausible conjectures; but this is not a scientific mode of procedure, unless we are content to regard these conjectures as working hypotheses in aid of researches yet without result. 
It is important that general truths of this kind, impressed upon us by our descent to the ascertained beginnings of life, should be generally known, as counteractive to the confident statements so frequently put forth by enthusiastic speculators and caterers of sensational popular science. In point of fact, we still occupy the position so long ago defined by the Apostle Paul, that "God's invisible things from the creation of the world are clearly seen, being understood by the things that are made, even His eternal power and divinity;" and the rational student of nature must still be a pupil in the school of the Almighty Maker of all things.

Realizing this, we can learn something both as to the dignity and the humility of our own position. On the one hand we perceive that, in the whole chain of life, man is the only being in the likeness of the Maker, fitted to be His deputy in the world, to understand His great work, and to be the heir of the whole. To man alone He has proclaimed, "I have said ye are gods, and all of you children of the Most High." To man alone has He given that "inspiration of the Almighty" which makes Him the interpreter of nature. On the other hand, when we consider the long extent in time of 
the great chain of life before man, and along with this the vast oceanic area inaccessible to us, yet ever since the dawn of life teeming with living things innumerable, we find that man is not even in this little world the only object of Divine care, and we learn a lesson of humility and of the obligations which rest on us not only in relation to our fellow-men, but toward our humbler companions who share with us the care of their Father and ours.

Finally, it is plain that scientific investigation can never bring us within reach of the absolute origin of life, otherwise than by the action of a creative Will. Had we stood on the earliest shore, and had we seen living things appear in the waters where before had been merely inorganic sand or rock, we should have known as little as we know to-day of even the proximate causes of this new departure in nature. If agnostics, we might have said, "this is spontaneous generation"; but such an expression would convey no distinct idea of the nature of the change which had occurred. It would be merely a cloak for our ignorance. If theists, we might say, "this is creation"; but we would have heard no audible fiat, nor seen any process or 
manipulation, nor known by what subordinate agency, if any, the result was produced. We could have given no further explanation than that of the ancient writer who tells us that God said, "Let the waters swarm with swarmers." We are told that when these great creative changes occurred, they were witnessed by higher intelligences than man. "Then the morning stars sang together, and all the sons of God shouted for joy"1; but even they could perhaps know little more than we, though they might be better able to trace the future development of the wonderful plan commenced in the humble Protozoa and culminating in man and immortality.

${ }^{1}$ Job xxxviii. 7 . 

APPENDIX 



\section{A P PENDIX}

\section{A. Geological Relations of Eozoon, ARCHAOZOON, ETC.}

$\mathrm{N}$ the text I have given the arrangement of the pre-Cambrian rock-formations of Canada, as understood by me at the time of the delivery of the lectures on which this work is based-an arrangement which I believe will, in the main, be sustained by the work of the future, but which cannot as yet be received as final. The work of Logan and Murray, so far as I have had opportunity to go over their ground, was admirable; but since their time the progress in the settlement of the country, the extension of railways, and other means of communication, and the opening up of mineral deposits have greatly increased the means of obtaining information, and detailed explorations have been in progress under the Geological Survey of Canada. At this moment, under the new Director of the Survey, Dr. G. M. Dawson, much work is being done in this 
difficult field, more especially by Dr. Ells, Dr. Adams, and Mr. Barlow, which it may be hoped will go far to settle finally the arrangement and distribution of pre-Cambrian rocks in the Northern part of the American Continent. The maps and detailed reports representing these explorations are not yet before the public, but from some preliminary notices which have appeared in scientific periodicals, it may be inferred that the distinction between the fundamental gneiss, with its associated igneous products, and the Upper Laurentian, will become greater than was supposed by Logan. The Lowest Laurentian or Trembling Mountain series of Logan now represents a very widely extended basement formation, not so far as can be ascertained, composed of sedimentary rocks in a metamorphosed state, but rather of peculiar aqueo-igneous materials, different from the greater part of those which succeeded them, and associated with varied and extensive igneous intrusions and in-meltings like those which Keilhau ascertained long ago in the case of similar rocks in Norway. The Grenville series, on the other hand, may prove to be a remnant of an overlying system, originally less extensive or bordering the older group, and greatly 


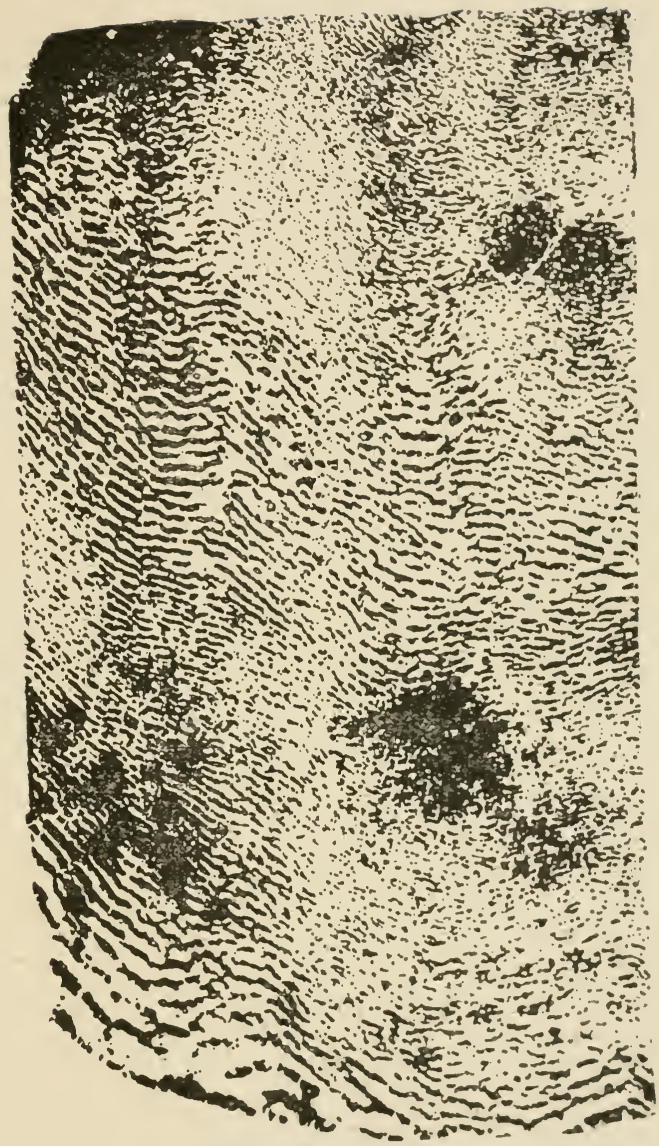

Fig. 6o.-Eozoon Canadense.

Portion of a large specimen. Nature-printed. Showing the laminx, and irregular cavities filled with serpentine, perhaps corresponding to the funnels.

[To face p. 296. 

attenuated by the enormous denudation which the whole region has undergone. It may also be found that the beds of limestone are fewer and their repetitions more numerous than had been supposed, and that the Grenville series may be closely associated locally, at least, with beds hitherto of uncertain age, or associated with the Lower Huronian. The Huronian proper, on the other hand, may be considerably extended, and the Kewenian and Animiké series overlying it have already been ascertained by the Canadian Geological Survey to overlap the Huronian and Laurentian over vast areas between the great lakes and the Arctic sea, evidencing much submergence at the close of the Huronian age, and opening of the Palæozoic. I have noticed in the text the apparently wide development of deposits of this age over the area of the Rocky Mountains of Canada, and the corresponding territories in the United States. There would seem to be in these regions a great thickness of unaltered sediments between the Lower Cambrian and the crystalline rocks below, representing the Huronian and Laurentian. In these very few fossils have yet been found, but they afford perhaps the most promising field, next to their representatives in Newfoundland 
and New Brunswick, for the discovery of the predecessors of the Olenellus fauna, and the forms of life connecting these with those known in the Huronian and Laurentian. [For summaries of facts on the last-mentioned subject, see Report of Dr. G. M. Dawson on the Kamloops map-sheet, in "Reports of Geological Survey of Canada," vol. vii. B, new series, pp. 29 et seq.; also Reports of Dr. C. D. Walcott, U. S. Geological Survey, vol. xiv., Part I., pp. IO3 et seq., and Part II., pp. 503 et seq.]

\section{B. Preservation of Organic Remains by injection witil Hydrous Silicates.}

The late Dr. T. Sterry Hunt contributed to the original paper on Eozoon in the Journal of the Geological Society, a valuable essay on the mineralization of fossils by serpentine, glauconite, and allied hydrous silicates. This was in part reprinted in the notes appended to one of the chapters of "The Dawn of Life," and the subject was further discussed by Hunt in his invaluable work, "Chemical and Geological Essays," and more especially in the chapter on the "Origin of Crystalline Rocks," a 
chapter which every geologist deserving the name should study with care.

I give here some of the more important facts referred to by Hunt, and may add that subsequent microscopic studies have familiarized me with the occurrence of serpentine and other hydrous silicates as fillings of the cavities of fossils of various geological ages, insomuch that I have come to regard the occurrence of these rocks in association with fossiliferous limestones as among the best available means to enable us to ascertain the minute structures of shells, Foraminifera, corals, etc.

The following remarks and analyses further illustrate Hunt's views on the relations of these minerals, with some of the facts on which they are based:-

"In connection with the Eozoon it is interesting to examine more carefully into the nature of the matters which have been called glauconite or greensand. These names have been giren to substances of unlike composition, which, however, occur under similar conditions, and appear to be chemical deposits from water, filling cavities in minute fossils, or forming grains in sedimentary rocks of various ages. Although greenish in colour, and soft and earthy in texture, it will be seen that the various 
glauconites differ widely in composition. The variety best known, and commonly regarded as the type of the glauconites, is that found in the greensand of Cretaceous age in New Jersey, and in the Tertiary of Alabama; the glauconite from the Lower Silurian rocks of the Upper Mississippi is identical with it in composition. Analysis shows these glauconites to be essentially hydrous silicates of protoxyd of iron, with more or less alumina, and small but variable quantities of magnesia, besides a notable amount of potash. This alkali is, however, sometimes wanting, as appears from the analysis of a green-sand from Kent, in England, by that careful chemist, the late Dr. Edward Turner, and in another examined by Berthier, from the calcaire grossier, near Paris, whicil is essentially a serpentine in composition, being a hydrous silicate of magnesia and protoxyd of iron. A comparison of these last two will show that the loganite, which fills the ancient Foraminifer of Burgess, is a silicate nearly related in composition.

I. Green-sand from the calcaire grossier, near Paris. Berthier (cited by Beudant, "Mineralogie," ii., I78).

II. Green-sand from Kent, England. Dr. Edward 
Turner (cited by Rogers, Final Report, Geol. N. Jersey, page 206).

III. Loganite from the Eozoon of Burgess.

IV. Green-sand, Lower Silurian; Red Bird, Minnesota.

V. Green-sand, Cretaceous, New Jersey.

VI. Green-sand, Lower Silurian, Orleans Island.

The last four analyses are by myself."

I. II. III. IV. V. VI.

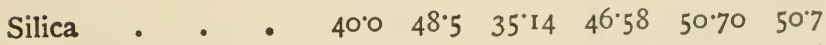

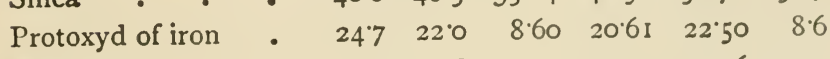

$\begin{array}{llllllll}\text { Magnesia. } & \cdot & 16.6 & 3.8 & 31.47 & 1.27 & 2.16 & 3.7\end{array}$

$\begin{array}{lllllllll}\text { Lime } & \cdot & \bullet & 33 & & & 2.49 & 1.11 & \\ \text { Alumina } & \cdot & . & 17 & 170 & 10.15 & 1145 & 8.03 & 19.8\end{array}$

$\begin{array}{lllllll} & \cdot & & & & & \\ \text { Potash } & - & & \text { traces } & 6.96 & 5.80 & 8.2\end{array}$

Soda • . . $\quad 98 \quad 75$ '5

Water $\begin{array}{llllllll}. & . & 12.6 & 7.0 & 14.64 & 9.66 & 8.95 & 8.5\end{array}$

$98^{\circ} 998^{\circ} 3 \quad 100.00100 .00100^{\circ} 00100.0$

An eminent example is the Silurian limestone of Pole Hill, in New Brunswick, collected by the late Mr. Robb, of the Geological Survey, and referred to in the text. I cannot doubt that the silicate injecting Crinoids and other fossils in this limestone must have been introduced into these when still recent, and the same remark applies to the serpen- 
tine filling a coral at Lake Chebogamong, and fragments of corals at Melbourne, in Eastern Canada, and to the similar mineral filling fossils in a limestone from Llangwyllog, in Wales, and in that of Maxville, Ohio. Hunt regarded all these as coming essentially into the same category as regard to general composition and properties. His analysis of the minerals from Pole Hill and Llangwyllog is as follows :-

Pole Hill. Llangwyllog.

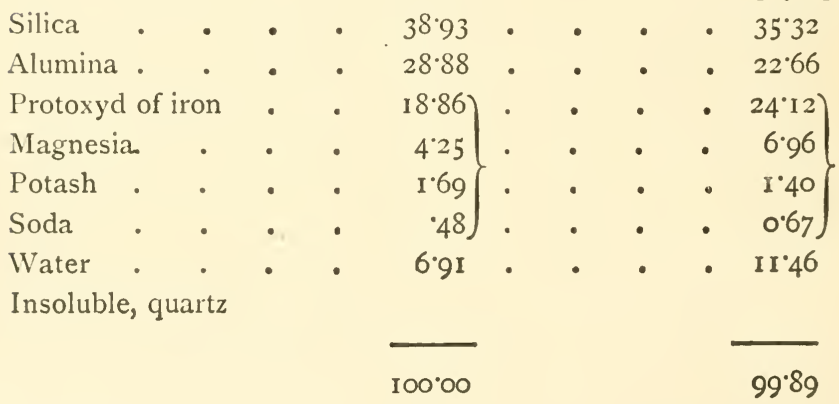

These minerals approach in composition to the jollyte of Von Kobell, from which they differ in containing a portion of alkalies, and only one half as much water. In these respects they agree nearly with the silicate found by Robert Hoffman, at Raspenau, in Bohemia, where it occurs in thin layers alternating with picrosmine, and surrounding 
masses of Eozoon in the Laurentian limestones of that region; ${ }^{1}$ the Eozoon itself being there injected with a hydrous silicate which may be described as intermediate between glauconite and chlorite in composition."

In the Welsh specimen the silicate is of a deep green colour, except where oxidized, and though only 3 per cent. of the whole, is sufficient to give it an olive colour and slight serpentinous lustre. In the Pole Hill material, the silicate amounts to 5 per cent. of the whole, and is of a greyish colour. For some further particulars, see my Paper on "Fossils Mineralized with Silicates" (Journal Geological Society, February, I879).

\section{Affinities of Eozoon, etc., with MORE MODERN FORMS.}

Dr. Carpenter, who in admirable papers, which I need not quote here, ${ }^{2}$ has illustrated in detail the

1 Journ. fur Prakt. Chemie, Bd., Io6 (1869), p. 356.

2 I may specially refer to the following :-

W. B. Carpenter on Eozoon Canudense. Intellectual Observer, No. xl., p. 300, 1865. Supplemental notes on the 
structures of Eozoon, and shown its resemblance to modern forms, places Eozoon as a generalized type between the Nummuline and Rotaline groups of Foraminifera. It resembles the former in its fine and complicated tubulations, and some of the larger sessile forms of the latter in its habit of growth. More especially, this is near to that of the genera Carpenteria and Polytrema. In the former, more especially, there are a number of somewhat flattened calcareous cells with perforated walls, and built up in a conical form around a central pipe or funnel into which the apertures of the cells open. A specimen of Carpenteria, enlarged

structure and affinities of Eozoon Canadense, Quart. Journ. Geol. Soc., Lond. Vol. xxii., pp. 219-228, 1866. Notes on the structures and affinities of Eozoon Canadense. Canad. Nat., new ser., vol. ii., pp. II I-I19, wood-cut, I865. A reprint from Quart. Journ. Geol. Soc., Lond., 1865. Further observations on the structure and affinities of Eozoon Canadense. In a letter to the President. Proc. Roy. Soc., Lond., vol. xxv., pp. 503-508, 1867. New observations on Eozoon Canadense. Ann. and Mag. Nat. Hist., ser. 4, vol. xiii., pp. 456-470, one plate, 1874. Final note on Eozoon Canadense. Ann. and Mag. Nat. Hist., ser. 4, vol. xiv., pp. 371-372, I 874. Remarks on Mr. H. J. Carter's letter to Prof. King on the structure of the so-called Eozoon Canadense. Ann. and Mag. Nat. Hist., ser. 4, vol. xiii., pp. 277-284, with two engravings, 1874 . 
and having the walls of its cells thickened by a supplemental tubulated deposit like that of Calcarina, would approach very near to Eozoon.

The question of the general relation of an organism like Eozoon to creatures known to us in the modern seas may be answered in either of two ways :- (I) Functionally or in relation to the position of such an animal in nature: or (2) Zoologically, or with reference to its affinities to other animals. With reference to the first consideration, the answer is plain. The geological function of Eozoon was that of a collector of calcareous matter from the surrounding waters, then probably very rich in calcium carbonate, and its role was the same with that of the Stromatoporæ and calcareous Sponges, smaller Foraminifera and Corals in latter times. The answer to the second aspect of the question is less easy. An ordinary observer would at once place Eozoon with the Stromatoporidæ or Layer-corals, which fill or even constitute whole beds of limestone in the Cambro-Silurian, Silurian and Devonian Periods. While, however, Eozoon has been claimed on the highest authority for the Rhizopods, the Stromatoporæ and their allies have been regarded as Sponges, or more recently as 
Hydroids allied to the Hydractiniæ and Millepores. ${ }^{1}$ I confess that I am not satisfied with these interpretations. I have in my collections large numbers of encrusting spinous forms, usually called Stromatoporæ, but which I have long set aside as probably Hydractiniæ. There are other forms with large vertical tubes which I have regarded as corals, but some Stromatoporæ seem to be different from either, and I am still disposed to regard many of them as Protozoa. Bearing in mind, however, that the Silurian is as remote from the Laurentian on the one hand as from the Tertiary on the other, we might be prepared to expect that if the Layer-corals of the Silurian are divisible into different groups, somewhat widely separated, and we have in the lower Palæozoic the peculiar type of Cryptozoon, we may be prepared to expect in the Laurentian much more generalized forms, less susceptible of classification in our modern systems. If, therefore, Eozoon were accessible to us in a living state, I should not be surprised to find that-while perhaps more akin to the calcareous-shelled Rhizopods than to any other modern group-it may have presented

${ }^{1}$ See Nicholson and Murie's able memoirs, Publications of Pal. Soc., 1885. 
points of resemblance to Sponges or even to Hydroids, in its skeleton and mode of growth, and even in the arrangement of its soft parts.

Taking this view of its nature and relations, the genus and the Laurentian species may be characterized as follows :-

\section{Genus EozooN, Dawson.}

Foraminiferal skeletons, with irregular and often confluent cells, arranged in concentric and horizontal laminæ, or sometimes piled in an acervuline manner. Septal orifices irregularly disposed. Proper wall finely tubulated. Intermediate skeleton with branching canals.

\section{Eozoon Canadense, Dawson.}

In inverted conical or rounded masses or thick encrusting sheets, frequently of large dimensions. Typical structure stromatoporoid, or with concentric calcareous walls, frequently uniting with each other, and separating flat chambers, more or less mammillated, and spreading into horizontal lobes and small chamberlets; chambers often confluent and crossed by irregular calcareous pillars connecting the opposite walls. Upper part often composed of acervuline chambers of rounded forms. Proper wall 
tubulated very finely. Intermediate skeleton largely developed, especially at the lower part, and traversed by large branching canals, often with smaller canals in their interstices. Lower laminæ and chambers often three millimetres in thickness. Upper laminæ and chambers one millimetre or less. Age Upper Laurentian and perhaps Huronian.

Var. MINOR. - Supplemental skeleton wanting, except near the base, and with very fine canals. Laminæe of sarcode much mammillated, thin, and separated by very thin walls. Probably a depauperated variety.

Var. ACERVULINA.-In oval or rounded masses, wholly acervuline. Cells rounded; intermediate skeleton absent or much reduced; cell-walls tubulated. This may be a distinct species, but it closely resembles the acervuline parts of the ordinary form.

Assuming the Archæospherinæ so abundantly found in the Eozoon limestones to be distinct organisms, and not mere germs or buds of Eozoon, they may be thus defined:-

\section{Genus Archeospherina, Dawson.}

A provisional genus, to include rounded solitary chambers, or globigerine assemblages of such cham- 
bers, with the cell-wall surrounding them tubulated as in Eozoon, or perhaps in some cases with simple pores like those of Rotalines. They may be distinct organisms, or gemmæ, or detached fragments of Eozoon. Some of them much resemble the bodies figured by Dr. Carpenter, as gemmæ or ova and primitive chambers of Orbitolites. They are very abundant on some of the strata surfaces of the limestones at Côte St. Pierre. Age Upper Laurentian.

I may add here the characters of Matthew's new genus, Archæozoon, as given by him:-

\section{Gemus ARchжOZOon, Mattherw.}

Skeleton composed of thin concentric laminæ convex upward, and having between them a granular layer filled with minute branching canals.

Archeozoon Acadiense, Matthew.

Habit of growth cylindrical in masses or groups, budding upward. The microscopic characters are thus given by Matthew: ${ }^{1}$ -

"The structures appear to be allied more closely to Cryptozoon than to Eozoon. The microscopic

${ }^{1}$ Bulletin No. ix., Nat. Hist. Soc. of New Brunswick, 1890. 
structure is most easily recognised in the earthy (as distinguished from the calcareous) layers, and consists of minute branching canals. Under a oneinch objective the smaller canals have the appearance of minute threads, which run sometimes for a distance of two millimetres without branching. The larger canals branch more frequently and are more sinuous. The canals cross and anastomose with each other; they run chiefly at right angles to the axis of the fossil, and appear to branch most in soing outward from the centre. More rarely they ascend from the earthy to the calcareous layer, branching upward."

In limestone of the Upper Laurentian, near St. John, New Brunswick.

\section{Cryptozoon.}

The description above given of Archæozoon very naturally leads us to consider the allied Cambrian and pre-Cambrian forms known as Cryptozoon.

This remarkable and problematical type was first described by Prof. James Hall in the Appendix to his Annual Report of I882 (No. 26). It is a large massive organism, occurring abundantly on the sur- 
face of a limestone of Calciferous (Upper Cambrian) age at Greenfield, Saratoga County, New York. The individuals sometimes attain a diameter of two feet, and are often surrounded by smaller specimens apparently budding off from them. Like Stromatoporæ, they consist of concentric laminæ, but these are concave upward, giving a bowl-shaped form to the summits of the individuals. Prof. Hall describes them as "made up of irregular concentric laminæ of greater or less density, and of very unequal thickness. The substance between the concentric lines in well-preserved specimens is traversed by numerous minute irregular canaliculi which branch and anastomose without regularity. The central portion of the masses is usually filled with crystalline granular and Oolitic material, and many specimens show the intrusion of these extraneous and inorganic substances between the laminæ."

Professor Hall having kindly presented some good specimens to the Peter Redpath Muscum, I have had sections made, and have thus been able to verify his description, and to compare the structures with those of some of the more ancient Stromatoporoid specimens in our collections, including the Archæozoon from New Brunswick, of 
which Mr. Matthew has presented a fine slab to the Museum. I have also, through the kindness of Professor Winchell, been enabled to compare these with his Cryptozoon Minnesotense, and Dr. Walcott has added specimens of his Stromatoporoid forms from the pre-Cambrian beds of Arizona. It would appear from these and other specimens in our collections from the Cambrian and older Ordovician beds, that we have here an ancient type of Stromatoporoid organism in which the original laminæ seem to have been thin and coriaceous, without apparent pores or pillars connecting them with each other, but having between them relatively thick layers of fine fragmental matter penetrated by numerous irregularly tortuous and branching tubes. The laminæ often present a carbonaceous or chitinous appearance, though frequently replaced by mineral matter, and the intervening layers show both a calcareous and carbonaceous substance, with much fine silicious sand often as rounded grains, and apparently some dolomitic granules. The tubules seem destitute of any distinct wall, otherwise the whole would resemble on a large scale the nodular and laminated masses of Girvanella, which Wethered has described as surrounding organic 
fragments in Silurian and Carboniferous and Jurassic limestones in England. ${ }^{1}$

The Streptochetus of Seely from the Chazy limestone $^{2}$ is evidently very near to Girvanella, if not generically identical, and I have a similar species from the Lower Cambrian pebbles in the conglomerates of the Quebec group. In all these forms, however, the thicker or intermediate laminæ seem to consist wholly of definite convoluted tubes, whereas in Cryptozoon the tubes, or tubular perforations, are separated by a mass of material which in the best preserved specimens seems to consist of a fibrous stroma including calcareous and silicious particles. It seems doubtful to what class of beings such a structure should be referred; but whatever its nature, it evidently had great powers of growth, and seems to be a very ancient form of life.

One of the species similar in structure to Hall's type, but budding out into turbinate branches, was discovered by Mr. E. T. Chambers, of Montreal, in the Ordovician limestone of Lake St. John, and has been named $C$. bcreale. It differs in structure from Hall's species in having the tubes less tortuous

1 British Association, Liverpool meeting, 1896.

2 Amer. Journ. of Science, I885. See Nicholson, "Mamual of Palæontology," ed. of r 889. 
and more nearly parallel to the lamince. In its outline it reminds one of the problematical Eozoon from the Hastings group at Tudor, Ontario, referred to in the text.

Should time permit, I hope to have all the specimens in our collections illustrating this interesting and primitive type examined and described. In the meantime I may merely remark that a near modern analogue would seem to be the gigantic arenaceous Foraminifer Neusina Agassizi, Goës, dredged by Alexander Agassiz in the Pacific, and described in the Bulletin of the Museum of Comparative Zoology (Vol. xxiii., No. 5, I892). The modern form, it is true, is flat and foliaceous; but some of the old species approach to this shape, and if we suppose the little cells of Neusina to represent the tubes of Cryptozoon, and the carbonaceous matter of the latter to be the remains of the chitinous stroma seen in some specimens, the general resemblance will be very close.

The whole subject of these peculiar Stromatoporoid forms extending from the Upper Cambrian to the Laurentian, deserves a full and careful investigation, for which I am endeavouring to collect material. 
E. Receptaculites AND ARChaicyathus.

In "The Dawn of Life" (1875), reference was made to the singular and complicated organisms of the Upper Cambrian and Ordovician systems known as Receptaculites, which at that time was generally regarded as foraminiferal, and is still placed by Zittel, in his great work on Palæontology, among forms doubtfully referable to that group. It has also been referred to Sponges, though on very uncertain grounds. It has not, however, so far as I am informed, been traced any farther back than the Upper Cambrian (Calciferous), and no structural links are known to connect it with either Eozoon or Archæozoon. For this reason it was omitted in the text; but I think it well to mention it here, and to direct attention to it as possibly one of the complex Protozoa which may be traced far back toward the beginnings of life. ${ }^{1}$

Another primitive and generalized genus mentioned in the text is Archceocyathus of Billings, whose headquarters seem to be in the Lower Cambrian, and which may probably be traced farther back.

1 Billings, "Palrozoic Times." 
Mr. Billings described the genus in his "Report on Canadian Fossils" (186I-64), taking A.profundus, from the Lower Cambrian of L'Anse à Loup, on the Labrador coast, in the first instance, as the type.

A few years later, my attention was attracted to this species by specimens presented to me by $\mathrm{Mr}$. Carpenter, a missionary on the Labrador coast, and which Mr. Billings kindly permitted me to compare with his specimens in the Museum of the Geological Survey, collected by the late Mr. Richardson, at L'Anse à Loup, in Labrador, in what were then called Lower Potsdam rocks. Slices of the specimens were made for the microscope, when it appeared that, though they had the general aspect of turbinate corals, like Petraia, etc., they were quite dissimilar in structure, more especially in their porous outer and inner walls and septa (see Fig. 5, p. 35). Yet they could scarcely be referred to the group of porous corals known in much later formations and in the modern seas. Nor could they be referred with much probability to Sponges, as they were composed of solid calcareous plates, which, as was evident from their textures, could not have been originally spicular. One seemed thus shut up. to the conclusion that their nearest alliance was with 
Foraminifera, and if so, they were very large and complex forms of that group, consisting of perforated chambers arranged around a central cavity. I accordingly mentioned them in this connection in I875, not as closely related to Eozoon, but as apparently showing the existence of very complex foraminiferal forms in the Lower Cambrian.

The specimens thus noticed were altogether calcareous, and were of the species named $A$. profundus by Mr. Billings. He had, however, referred to the same genus silicified specimens from a later formation, the Calciferous (Upper Cambrian) at Mingan, under the name A. Minganensis, which were subsequently found to be associated with spicules resembling those of lithistid sponges, and which proved to be very different from the Lower Cambrian form, and are now referred to a different genus. The subject had thus become involved in some confusion, and was left in this state by Mr. Billings on his death. I therefore asked my friend, Dr. Hinde, of London, to re-examine my specimens, and at the same time those of the Geological Survey were placed in his hands by Mr. Whiteaves. Hinde also obtained specimens from Lower Cambrian rocks in Sardinia, where they seem to be abundant, and 
from Spain. He states the results of his examinations very fully in a paper in the Journal of the Geological Society of London. ${ }^{1}$ He retains the original name for the older and calcareous form from L'Anse à Loup, separating from it, however, another form, A. Atlanticus of Billings's, which is destitute of distinct radiating septa and acervuline, like the lower part of $A$. profundus. This he names Spirocyathus. The Mingan species he places with Sponges under the generic name, Archeoscyphia. In this Walcott substantially agrees with Hinde in his "Memoir on the Lower Cambrian Fauna." Both seem to refer Archæocyathus to corals, though admitting its very exceptional and anomalous structure. I think, however, we may still be allowed to entertain some doubts as to the reference to corals, more especially as the skeleton does not seem to have consisted of aragonite, but of ordinary calcite, like that of the Foraminifera. It is in any case a primitive form which seems to be dying out in the Lower Cambrian, and we may hope that it may be traced into the pre-Cambrian, and may form a link connecting the Palæozoic with the Eozoic faunas. In my description of it in "The

1 Vol. xlv., 1889, pp. 125 et seq. 
Dawn of Life" in I875, I used the following terms :- " To understand Archæocyathus, let us imagine an inverted cone of carbonate of lime from an inch or two to a foot in length, with its point planted in the mud in the bottom of the sea, while its open cup extends upward into the clear water. The lower part buried in the bottom is composed of an irregular network of thick calcareous plates, enclosing chambers communicating with one another. Above this, where the cup expands, its walls are made up of inner and outer plates, perforated with numerous round pores in vertical rows, and connected with each other by vertical partitions also perforated, so as to establish a free communication of the enclosed radiating chambers with each other, as well as with the water within and without. Such a structure might no doubt serve as a skeleton for a coral of somewhat peculiar internal structure, but it might just as well accommodate a protozoan with chambers for its sarcode, and pores for emission of pseudopods, both outwardly and by means of the interior cup, which in that case would represent a funnel like that of Carpenteria, or one of the tubes of Eozoon."

On the whole, when we consider the magnitude 
and synthetic character of such forms as Cryptozoon, Receptaculites, and Archæocyathus, and their association with generalized types of Crustaceans and Brachiopods, we can scarcely fail to perceive that at the base of the Palæozoic we are leaving the reign of the higher marine invertebrates, and entering on a domain where lower and probably Protozoan forms must be dominant, and so are getting at least within calculable distance of the beginnings of life.

\section{F. Pre-Geological Evolútion.}

Reference is incidentally made in the text to the doctrine implied in the old notion of successive cataclysms and renewals of the earth, held by some ancient mythologies and philosophies, and revived in a slightly different form by Mr. Herbert Spencer, in connection with the requirements of the Darwinian evolution by natural selection. This primitive idea was illustrated at considerable length by Professor Poulton in his address as President of the Zoological Section of the British Association at its meeting in Liverpool (September, I896). In this new and ably presented form, it deserves some notice 
as excluding the hope of our finding the beginnings of life in any geological formations at present known.

Professor Poulton refers to the argument used by Lord Salisbury, in his address at the Oxford meeting, on the insufficiency of time for the requirements of the Darwinian evolution. He then discusses the estimates based by Lord Kelvin and Professor Tait on physical considerations, and dismisses them as altogether inadequate, though he admits that Professor George Darwin agrees with Lord Kelvin in regarding 500 millions of years as the maximum duration of the life of the sun.

He next takes up the estimates of geologists, and rather blames as too modest those who ask for the longest time, say 400 millions of years, for the duration of the habitable earth. He evidently scarcely deems worthy of notice the more moderate demands of many eminent students of the earth, who have based far lower estimates on more or less reliable data of denudation and deposition, and on the thickness of deposits in connection with their probable geographical extent.

$\mathrm{He}$ then proceeds to consider the biological evidence, and dwells on the number of distinct types 
represented as far back as the Lower Cambrian. Independently of the interpretations and explanations of this great fact, the numerous types there represented, and the persistence of some of them to the present day, give an almost overwhelming impression of the vast duration of organisms in time. In connection with the supposed slow and gradual process of evolution, this naturally leads to the conclusion that "the whole period in which the fossiliferous rocks were laid down must be multiplied several times for this later history (that of the higher groups of animals alone). The period thus obtained requires to be again increased, and perhaps doubled for the earlier history." Ordinary geologists naturally stand aghast at such demands, and inquire if they are seriously put forth, and if it would not be wise to hesitate before accepting a theory on behalf of which such drafts on time must be made. The late Edward Forbes once humorously defined a geologist to be "an amiable enthusiast who is happy and content if you will give him any quantity of that which other men least value, namely, past time." But had this great naturalist lived to "post-Darwinian" times, he might have defined a Darwinian biologist to be an insatiable 
enthusiast, who feels himself aggrieved if not supplied with infinity itself, wherein to carry on the processes of his science. Seriously however, the necessity for indefinitely protracted time does not arise from the facts, but from the attempt to explain the facts without any adequate cause, and to appeal to an infinite series of chance interactions apart from a designed plan, and without regard to the consideration, that we know of no way in which, with any conceivable amount of time, the first living and organized beings could be spontaneously produced from dead matter. It is this last difficulty which really blocks the way, and leads to the wish to protract indefinitely an imaginary process, which must end at last in an insuperable difficulty.

Were Evolutionists content to require a reasonable time for the development of life, and to assign this to an adequate cause, they might see in the reduction of living things in the pre-Cambrian ages to few and generalized or synthetic types, evidence of an actual approach to the beginnings of life, and beyond this to a condition of the earth in which life would be impossible. 


\section{G. Controversies Respecting Eozoon.}

In the text (Chapter IX.) I have referred in a cursory manner to these, but have felt that it would be unprofitable to fight the old battles over again, except in so far as the objections raised have suggested new lines of study and investigation. The old objections of Messrs. Rowney, King and Carter were conclusively replied to by the late Dr. Carpenter. The later criticisms of Möbius in his elaborated memoir in "Palæontographica" were in appearance more formidable; but he had evidently entered on the question with imperfect material, and a very defective conception of its extent and meaning. His treatment of it was also marked by unfairness to those who had previously worked at the subject, and by that narrow specialism and captious spirit for which German naturalists are too deservedly celebrated. The difficulties he raised were met at the time, more especially in articles by the present writer in the American Journal of Science, and in the Canadian Naturalist. Möbius, I have no doubt, did his best from his special and limited point of view; but it was a crime which science should not readily pardon or forget, on the 
part of editors of the German periodical, to publish and illustrate as scientific material a paper which was so very far from being either fair or adequate.

The later objections of Gregory and Lavis are open to similar criticism as imperfect and partial, and as confounding Eozoon with mineral structures which previous writers had carefully distinguished from it. I have stated these points in letters to Nature and to the Council of the Dublin Academy, and have also re-stated the evidence bearing on the animal nature of Eozoon in a series of papers in the Geological Magazine for I895. I may add here, as apposite to the present condition of the matter, a few remarks referring to the appearance of Eozoon in Dr. Dallinger's new edition of Carpenter's great work on the Microscope, ${ }^{1}$ and more especially to his retaining unchanged the description of Eozoon Canadense, as a monument of an important research up to a certain date, while adding a note with reference to the later criticisms of Mr. Gregrory.

Dr. Carpenter devoted much time to the study of Eozoon, and brought to bear on it his great experience of foraminiferal forms, and his wonderful

1 Nature, March 17, 1892. 
powers of manipulating and unravelling difficult structures. After having spent years in studying microscopic slices of Eozoon and the limestones in which it occurs, I have ever felt new astonishment when I saw the manner in which, by various processes of slicing and etching, and by dexterous management of light, he could bring out the structure of specimens often very imperfect. Not long before Dr. Carpenter's death, I had an opportunity to appreciate this in spending a few days with him in studying his more recently acquired specimens, some of them from my own collections, and discussing the new points which they exhibited, and which unhappily he did not live to publish. Some of these new facts, in so far as they related to specimens in our cabinet here, have since that time been noticed in my résumé of the question in the "Memoirs of the Peter Redpath Museum," I 888.

Those who know Dr. Carpenter's powers of investigation will not be astonished that later observers, without his previous preparation and rare insight, and often with only few and imperfect specimens, should have failed to appreciate his results. One is rather surprised that some of them have ventured to state with so great confidence 
their own negative conclusions in a matter of so much difficulty, and requiring so much knowledge of organic structures in various states of mineralization. For myself, after working fifty years at the microscopic examination of fossils and organic rocks, I feel more strongly than ever the uncertainties and liabilities to error which beset such inquiries.

As an illustration in the case of Eozoon: since the publication of my memoir of I 888 , which I had intended to be final and exhaustive as to the main points in so far as I am concerned, I have had occasion to have prepared and to examine about 200 slices of Eozoon from new material; and while most of these have either failed to show the minute structures or have presented nothing new, a few have exhibited certain parts in altogether unexpected perfection, and have shown a prevalence of injection of the canal system by dolomite not previously suspected. I have also observed that unsuitable modes of preparation, notably some of those employed in the preparation of ordinary petrological slices, may fail to disclose organic structures in crystalline limestones when actually present. Since that publication also, the discoveries of Mr. Matthew in the Laurentian of New Brunswick, and 
the further study of the singular Cambrian forms of the type of Cryptozoon, have opened up new fields of inquiry.

I think it proper to state, in reference to Dr. Dallinger's footnote on the recent paper of $\mathrm{Mr}$. Gregory, that it must not be inferred from it that Mr. Gregory had access to my specimens from Madoc and Tudor, though he no doubt had excellent material from the collections of the Canadian Geological Survey. It might also be inferred from this note that I have regarded the Madoc and Tudor specimens as "Lower Laurentian." The fact is, that I was originally induced in 1865 , by the belief of Sir W. E. Logan at that time that these rocks were representatives in a less altered state of the middle part of the Laurentian, to spend some time at Madoc and its vicinity in searching for fossils, but discovered only worm-burrows, spicules, and fragments of Eozoon, which were noticed in the Fournal of the Geological Society for I 866. (The more complete specimen from Tudor was found by Vennor in I866.) On that occasion I satisfied myself fully that the beds are much older than the Cambro-Silurian strata resting on them, unconformably; but I felt disposed to regard them 
as more probably of the age of some parts of the Huronian of Georgian Bay, which I had explored with a similar purpose under Logan's guidance in I 856 .

[In my subsequent notice of the Tudor specimens in "The Dawn of Life," in 1875, I referred to their age as "Upper Laurentian or Huronian"; and I may add, that while it is certain that the beds containing them are pre-Palæozoic, their place in the Eozoic period is still not precisely determined. Work is, however, now in progress which it is hoped may finally settle the age of the "Hastings group" and the old rocks associated with it. I may add that the specimen of Cryptozoon discovered by Mr. Chambers, and of which a portion is represented in the Frontispiece, seems to me to throw a new light on the Tudor specimen. It shows in any case the survival of Cryptozoa similar in form and general appearance to that specimen, as late as the Cambro-Silurian or Ordovician.]

H. Notes to Appendix, December, I896.

While this work was going through the press, I have received the Report of the U.S. Geological 
Survey for I 894-95, containing the elaborate Memoir of C. R. Van Hise on the pre-Cambrian Geology of North America. It is a very valuable contribution to the literature of this difficult subject, and will constitute a standard book of reference: though I think the use of the term "Algonkian" for groups of beds which are in part basal Palæozoic and in part Eozoic or Archæan is to be deprecated, and scarcely sufficient importance is attached to the labours of the early Canadian explorers in this field.

In the past summer I was enabled to spend a few days, with the assistance of my friend Mr. H. Tweeddale Atkin, of Egerton Park, Rock Ferry, in examining the supposed pre-Cambrian rocks of Holyhead Island and Anglesey. Fossils are very rare in these beds. As Sir A. Geikie has shown, the quartzite of Holyhead is in some places perforated with cylindrical worm-burrows, and in the micaceous shales there are long cylindrical cords, which may be algæ of the genus Palcoochorda, and also bifurcating fronds resembling Chondrites; but I saw no animal fossils. I have so far been unable to discover organic structure in the layers of limestone associated with apparently bedded serpentine in the southern part of Holyhead Island. In central Anglesey there are lenticular 
beds of limestone and dolomite associated with preCambrian rocks, which Dr. Callaway regards as probably equivalent to the Pebidian of Hicks. In these there are obscure traces of organic fragments; and in one bed near Bodwrog Church I found a rounded laminated body, which may be an imperfectly preserved specimen of Cryptozoon, or some allied organism. The specimens collected have not, however, been yet thoroughly examined. These and other pre-Cambrian deposits in Great Britain correspond in their testimony, with the Eozoic rocks of North America, as to the small number and rarity of fossil remains in the formations below the base of the Palrozoic, and the consequent probability that in these formations we are approaching to the beginning of life on our planet; though there is still reason to hope that additional oases of life may be found in these deserts of the pre-Palæozoic. Such rare intervals of fertility should be the more valued when the labours of so many skilled observers have proved so meagre in their results in comparison with the great extent and thickness of the beds which have been explored. 


\section{N D E X}

PAGE

Adams on composition of Laurentian schists . . . 108

— his work on Laurentian stratigraphy . • • . 296

Animals, Cambrian, classes of . . . . . . 7, I I

— pre-Cambrian . • . . . • . 53

- Huronian . • . . . . . . 67

— Grenvillian . . . . . . . 73,303

Antiquity, relative . • . • . • • . 6

Aquatic animals, permanence of . . . . . 13

Aragonite in fossils . . . . . . . 1 I7

Archæocyathus . . . . . . . . 35, 315

Archæozoon . . . . . . . . 214,309

Barlow, his explorations . • . • . . . 296

Bavaria, Eozoon of . . . . . . . • 7 I

Beecher on limbs of Trilobites . . . . . 25

Bicknell on Eozoon . . . . . . . . I4I

Billings on Eozoon . • • . • . • . 137

- on Receptaculites . . . . . . . 315

— on Archæocyathus . . . . . . 316

— on Signal Hill fossils. . . . . . . 54

Bonney on Côte St. Pierre . . . . . . 142

Burbank on Chelmsford Eozoon . . . . . I4I

Calcarina • • • • • • • • • 186

Calumet, Grand, Eozoon of $\quad$ • • • . . I30 
Canals of Eozoon

Cambrian, life of Early $\quad$ • $\quad$ • • • • • 17

geography of the . . . . . . 18

Carbon in Laurentian limestone $\quad$. $\quad$ • $\quad$ • 93

Carpenter, Dr., on Eozoon 137, 303, 324

Cayeux on Huronian fossils . • . • . . 68

Chambers, Mr. E. T. . • • . • • • • 313

Chrysotile, veins of . . . . . . . 161,239

Cœnostroma . • . • . • • • . 174

Colorado cañon . $\quad . \quad$. $\quad . \quad$. 56

Controversies respecting Eozoon . • • • • 324

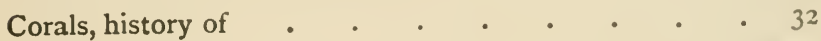

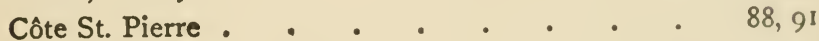

Cryptozoon. . . . . . . . 36, 56,310

Dallinger, note on Eozoon . • • • • • • 325

Dawson, Dr. G. M. • • • • • • • 66, 295

Ells, Dr. • . • • • • • • • 217,296

Eozoon, its discovery. $. \quad . \quad$. . . . 73, 125

— its general form . . . . . . . . 149

— its mode of occurrence . . . . . . 90

— its state of preservation . . . . . . 111

— its laminæ and chambers . . . . 152, 157

— its canals and tubuli . . . . 133, 138, 158, 160

— its funnels . . . . . . . . 152

— its minute granular structure . . . . . 133

— its characters and affinities . . . . 307

- objections to its animal nature . . . . . 221

— acervuline specimens. . . . . . . 203

— in various places $. \quad . \quad . \quad . \quad . \quad$ 141, 233

— Bavarian species . . . . . 71,213

— Tudor specimen $\quad . \quad$. . . . . 68

- fragments of, in limestones . . . . 183 
Eozoon, restoration of

Eozoic time as a geological age.

Etcheminian system

— fossils of

Evolution, pre-geological

Foraminifera, notice of modern .

- Etcheminian

\section{-} Huronian

Fossils, how mineralized

Glauconite, mineralizing fossils . Granular structure in Eozoon Graphite of the Laurentian Gregory on Eozoon

Grenvillian series

Gresley on Huronian worms Gümbel on European Eozoon

- 54

- 320

- 175

- 59

- $7 \mathrm{I}$

- 303

. I I I

217,298

. $\mathrm{s} 65$

- 93

235,325

- 39

. 68

7I, 213

Hall, Dr. James, on Cryptozoon . . . 36, 310 Hanford Brook, section at . . . . . 5 I Hastings series (Huronian ?) . . . . . . 67 Hinde on Archæocyathus . . . . . . 34, 317 Hunt, Dr. Sterry, on indications of life . • • 97 — on silicates in fossils . . . . . . . 298 Huronian system . • . . . . • • 65 Hymenocaris . . . . . . • 27

Jones, T. Rupert, on Eozoon - • • • • 75, I37 Jullien on Eozoon • • • • • • • • 235

Kewenian or Kewenawan series • • • • 48

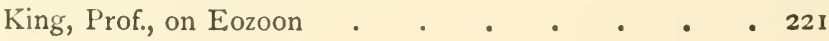




\section{Laurentian system} its limestones

Lavis, Dr. Johnson, on Eozoon .

Life in Early Cambrian

- in pre-Cambrian

in Huronian

in Laurentian

Limestones of Laurentian . • • • • • • 92

Logan, Sir W., on Eozoon . • • • • • • • 129

Loganite in Eozoon . . • • • • . 128

Long Lake, Specimens from . . . • • 190, 208

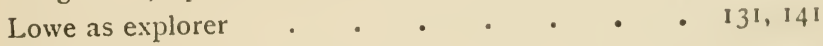

Map of Laurentian America $\quad$ • • • • 85

- Grenville limestone . • . . • • . 88

Matthew, Dr., on Archæozoon • • • • • 214, 309

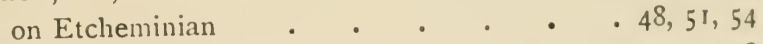

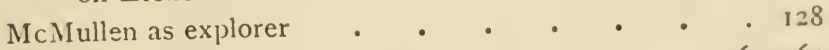

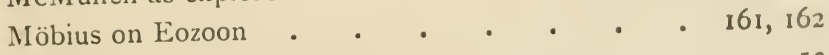

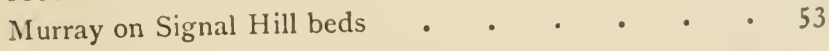

Nummulite $\quad$ • • • • • • • 163,186

$\cdot+\cdot . \quad 22 \mathrm{I}$

Ocean of Cambrian . . . . . . 18,21

— of Laurentian . • . • . . • • 85

Olenellus zone • $•$ •

Petite Nation • • • • • • • • • 141

Pole Hill, specimen from . . . . . . . 118

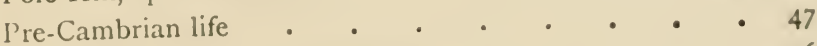

Pre-Cambrian rocks in Canadia . . . . . 76

Pre-geological evolution . • • • • • • 320

Pre-Palæozoic life . . • . . . . . 216

Pyroxene in Eozoon . . . . . . . 167, 169 


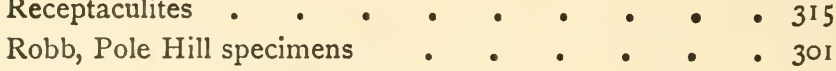

Serpentine, mineralizing fossils . • • • . . 147

— different origins of . . . . . . 167, 171

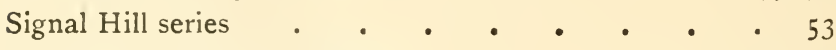

Silicates, mineralizing fossils • • • • 217,298

Spines, use of . . . . . . . . 30

Stromatoporæ • • • • • • • • 173

St. Pierre, Côte • • • • • • • • $\quad$ • 88,9 I

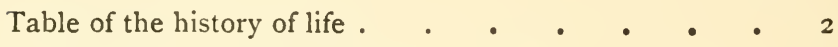

— of pre-Cambrian formations • • • • 76

Triarthrus • • • • • • • • • 25

Tubuli of Eozoon . . . . . . 60, 6I, 159

Van Hise on pre-Cambrian . . . . . 66, 329

Varieties of Eozoon . • • • • . • 107, 202

Vennor referred to $. \quad . \quad . \quad . \quad . \quad . \quad .69$

Walcott on Lower Cambrian . . • • • 40, 62

— on fossils, Colorado Cañon . • • • 57

Weston, Mr., referred to . . . . . . . I3I

White, Prof. C. A., on chronology of life . • • 7

Wilson, Dr., referred to . . . • • • • 127

Worm-burrows in Huronian . • • • • 67

Worm-trails in Lower Cambrian, etc. • . . 40,43 



